\title{
Archival and Historical Research for the San Pedro Creek Channel Improvement Project: The 1989-1990 Investigations
}

Herbert G. Uecker

Follow this and additional works at: https://scholarworks.sfasu.edu/ita

Part of the American Material Culture Commons, Archaeological Anthropology Commons, Environmental Studies Commons, Other American Studies Commons, Other Arts and Humanities Commons, Other History of Art, Architecture, and Archaeology Commons, and the United States History Commons

Tell us how this article helped you.

This Article is brought to you for free and open access by the Center for Regional Heritage Research at SFA ScholarWorks. It has been accepted for inclusion in Index of Texas Archaeology: Open Access Gray Literature from the Lone Star State by an authorized editor of SFA ScholarWorks. For more information, please contact cdsscholarworks@sfasu.edu. 


\section{Archival and Historical Research for the San Pedro Creek Channel Improvement Project: The 1989-1990 Investigations}

\section{Creative Commons License}

\section{(c) (1) (8)}

This work is licensed under a Creative Commons Attribution-NonCommercial 4.0 International License 


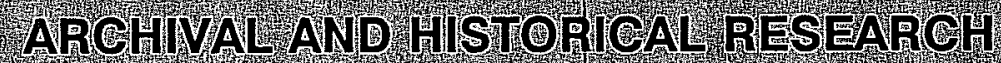

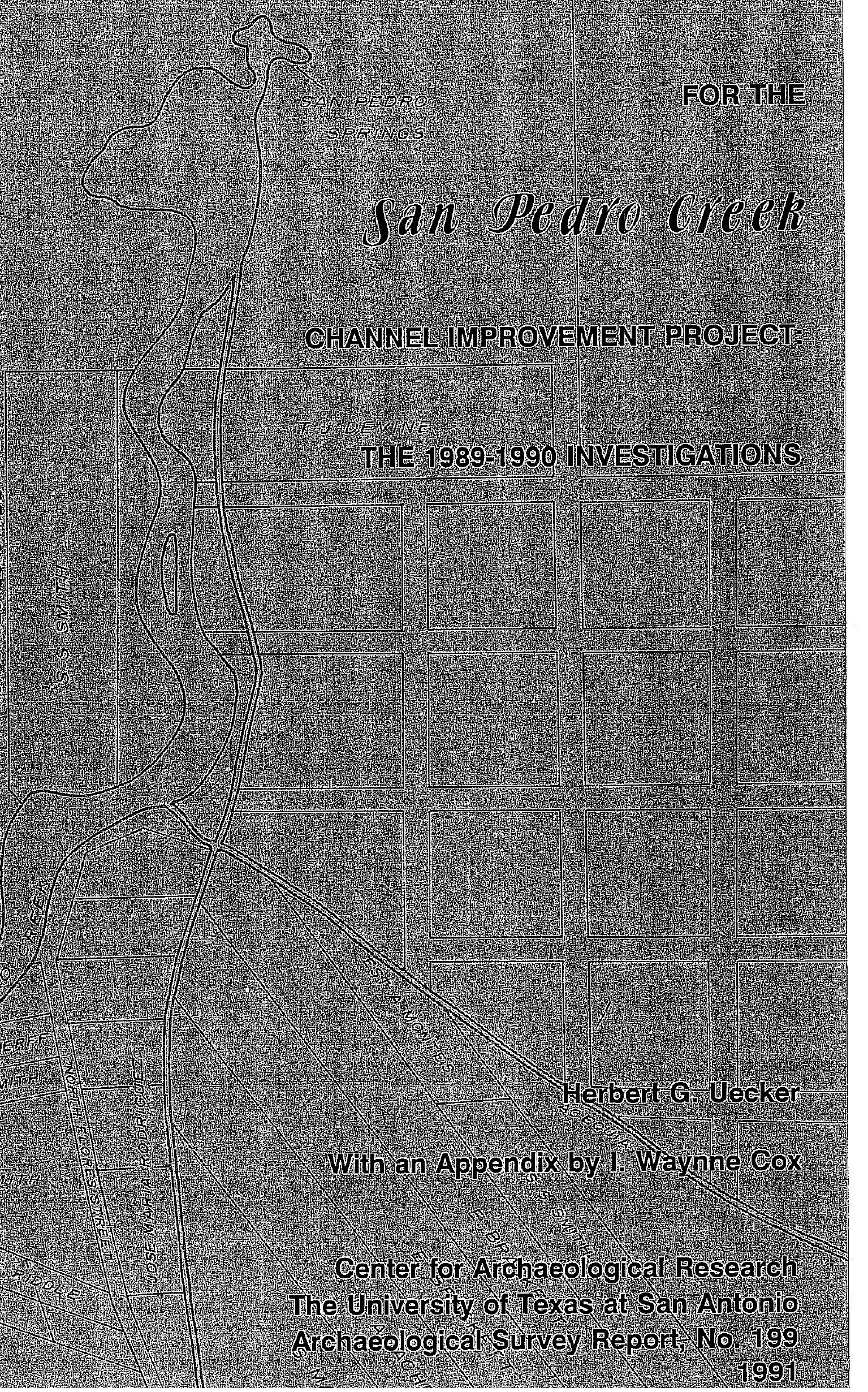





\section{ARCHIVAL AND HISTORICAL RESEARCH FOR THE SAN PEDRO CREEK CHANNEL IMPROVEMENT PROJECT: THE 1989-1990 INVESTIGATION}

Herbert G. Uecker

With an Appendix by I. Waynne Cox

Center for Archaeological Research The University of Texas at San Antonio ${ }^{\circledR}$ Archaeological Survey Report, No. 199 
This book is printed on acid-free paper (Cougar No. 1 Opaque Offset).

A list of publications offered by the Center for Archaeological Research can be obtained by sending $\$ 1.00$ to the Center for Archaeological Research, The University of Texas at San Antonio, San Antonio, Texas 78249-0658. 


\begin{abstract}
The history, cultural resources, and archaeological potential of a portion of San Pedro Creek in the vicinity of the Five Points intersection in central San Antonio were investigated and evaluated. Archival sources were consulted, personal interviews conducted, and an on-site inspection of the area was made. Based on the archival research, the history of the area was divided into several distinct periods. Data from primary sources are summarized and cross-referenced in an appendix.
\end{abstract}




\section{TABLE OF CONTENTS}

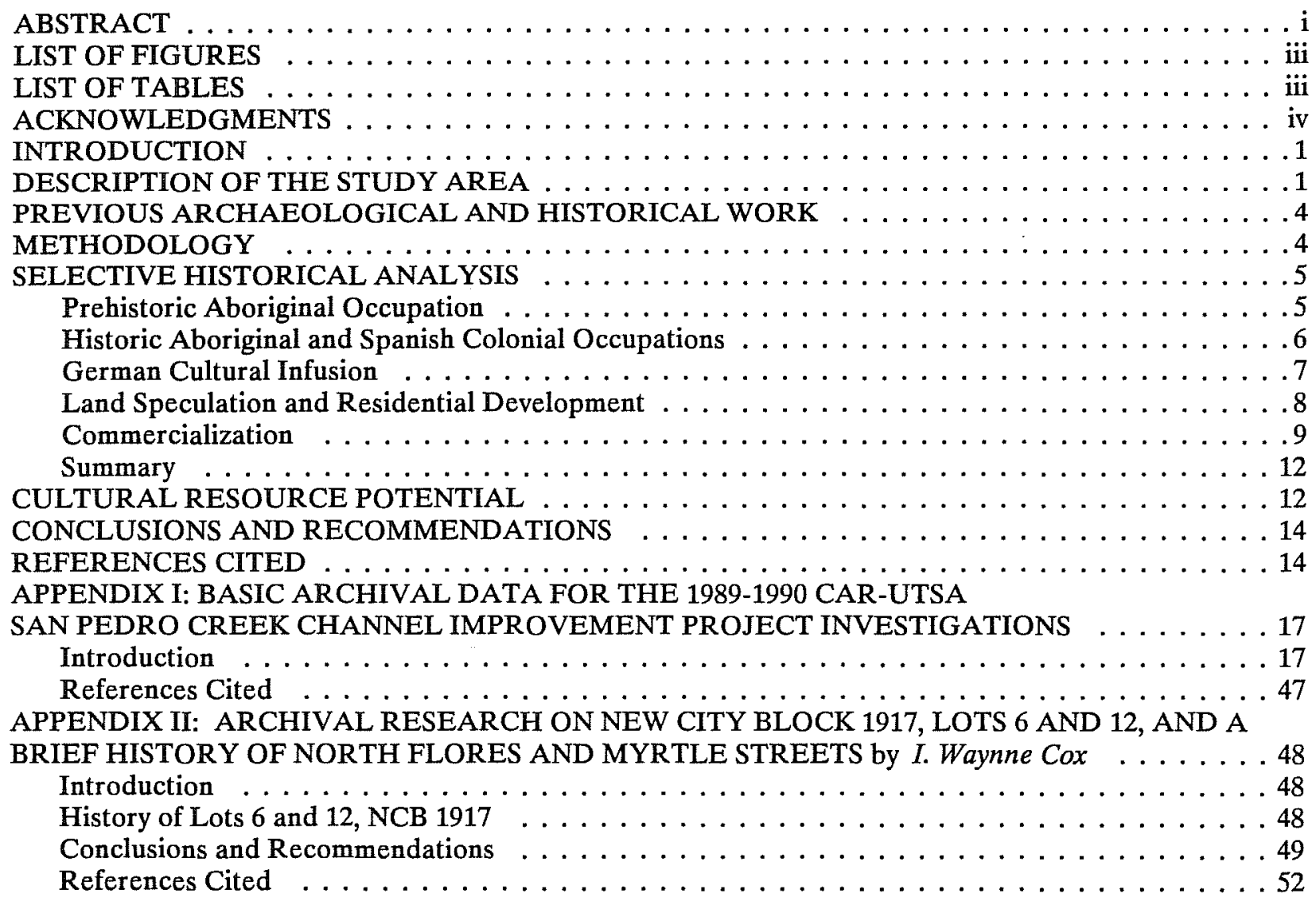




\section{LIST OF FIGURES}

1. Configuration of Streets and Blocks near the Five Points Intersection in San Antonio, Texas, $1990 \quad$. .2

2. Views of the Five Points Area, $1990 \ldots \ldots \ldots \ldots \ldots \ldots \ldots \ldots$

3. Section of San Pedro Creek and Surrounding Lands Encompassing the Study Area in the Mid-19th

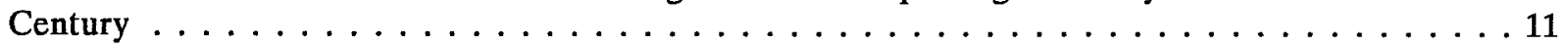

4. The Jacob Wohlfarth Structure, ca. $1885 \ldots \ldots \ldots$. . . . . . . . . . . . . . . . . . 49

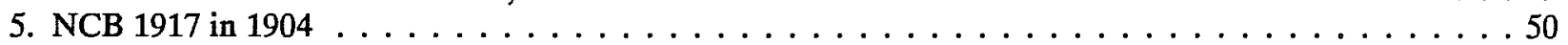

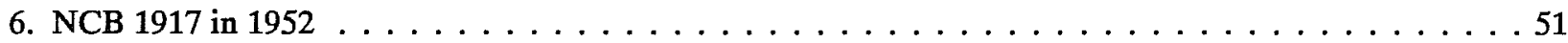

\section{LIST OF TABLES}

1. City Directory Data on Names from Friesleben Plat of $1855 \ldots \ldots \ldots \ldots \ldots$

2. City Directory Data on Property Owners on the East Side of San Pedro Creek Shown on Plats of the Late 19th Century to Early 20th Century . . . . . . . . . . . . . . . . . . 20

3. City Directory Data on Property Owners on the West Side of San Pedro Creek Shown on Plats of the Late 19th Century to Early 20th Century . . . . . . . . . . . . . . . . . 27

4. Addresses of Properties Abutting San Pedro Creek from Sanborn Insurance Maps . . . . . . . . . . 31

5. City Directory Data on Miscellaneous Residents and Businesses in or near the San Pedro Creek-Five

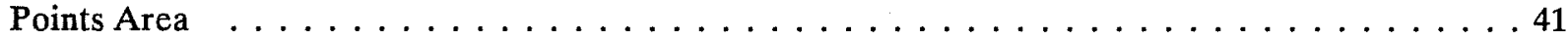




\section{ACKNOWLEDGMENTS}

Anne A. Fox and I. Waynne Cox, CAR research associates, shared their expertise in archival and historical research, and their special knowledge of the study area. Several persons provided information which might not otherwise have been available. Two were particularly helpful: Wayne Hubinger, the owner of Alamo Hardwoods, and Andrew H. Banda, owner of Andy's Barber Shop, who generously supplied information about the history of the Alamo Hardwoods Building and the Five Points intersection. Mr. Albert ("Rick") Grimm, librarian at the San Pedro Park branch of the San Antonio Public Library, helped with documentary leads and conducted a tour of San Pedro Park. Terry Conn and David Schweers, both with the San Antonio River Authority, lent general support to the research and also provided maps and other information about the study area. Nathaniel Jones of the VIA Metropolitan Transit Authority supplied information and a map regarding the VIA property north of Five Points. Jim Heath and Donny Dennis of Stewart Title Company in San Antonio cooperated in allowing access to their company's impressive archival materials. Bexar County archivist John O. Leal supplied information on the former existence of the 1860 s vintage Arter Crownover home within the study area. Frances K. Meskill drafted the maps and the cover design for this report. The efforts of the CAR administrative and office staff in editing and manuscript preparation are especially appreciated. 


\section{INTRODUCTION}

In September 1989, the San Antonio River Authority (SARA) contracted with the Center for Archaeological Research (CAR), The University of Texas at San Antonio (UTSA), to investigate the history and cultural resource potential of a section of San Pedro Creek near the intersection that has been known for many decades in San Antonio as Five Points. The intersection is located at the junction of Fredericksburg Road with Camaron, North Flores, North Laredo, and Laurel Streets. Prior to the CAR-UTSA study, the fascinating background of the area around the intersection had attracted the attention of local business owners, history buffs, scholars, and researchers.

Under existing antiquities laws, any cultural or historical resources to be affected by modification or relocation of portions of the channel of San Pedro Creek near the Five Points intersection needed to be identified and evaluated prior to commencement of construction. The gathering of information was begun as soon as the contract was activated and continued through the early part of 1990. Appendix I presents the basic archival data from city directories and Sanborn insurance maps. Appendix II presents archival information from earlier research by I. Waynne Cox for the Five Points intersection.

Technical staff assistant Herbert G. Uecker performed most of the archival research, interviews, analysis, and report writing. Anne A. Fox and I. Waynne Cox, research associates, provided source information on the general history of San Antonio and on the study area in particular. Cox and Uecker performed a brief on-the-ground survey and evaluation of the cultural resource and preservation potential of the area. Frances K. Meskill, technical staff assistant, drafted the maps for this report. General supervision of the project was provided by Jack D. Eaton, CAR acting director and principal investigator.

\section{DESCRIPTION OF THE STUDY AREA}

The CAR-UTSA study focused on a section of San Pedro Creek approximately one half mile long, bounded on the south by Interstate Highway 10 and on the north by Myrtle Street (Fig. 1). The Five Points intersection is in the approximate geographic center of the area. At the time of the study, both sides of the portion of the creek examined were commercially developed. From north to south, starting at Myrtle Street, and ending at Interstate
Highway 10 near Poplar Street, the following establishments were noted:

1. The main administrative offices, maintenance garages, and vehicle parking areas for San Antonio's VIA Metropolitan Transit Authority included a contiguous 29 acres, extending from Myrtle Street on the north to Laurel Street on the south, and from North Flores Street on the west nearly to San Pedro Avenue on the east. The section of San Pedro Creek within the VIA Metropolitan Transit property was landscaped, and the banks were stabilized by stonework. The ground surface adjacent to the creek had been leveled, and various sections were finished in either asphalt or concrete for parking lots and walkways, or were planted in domestic turf, ground covers, shrubs, and trees.

2. Mutually adjoining buildings were located at the northeast corner of the intersection of North Flores and Laurel Streets, including Repete at Pete's Wine-Liquor-Beer and Rosenburg Bros. Supply Co.

3. Located almost directly south of and across the Five Points intersection from Repete at Pete's Wine-Liquor-Beer and on the east side of North Laredo Street was Murf's Better Burger.

4. Alamo Hardwoods Building and yard were on the southwest corner of the Five Points intersection where North Laredo Street meets Fredericksburg Road (Fig. 2,a).

5. Two, nearly adjacent, one-story storage buildings constructed of sheet siding and roofing over domed metal frames faced east toward North Laredo Street between Lombrano Street on the north and Zircon Street on the south. The occupancy and usages of these buildings at the time of the study were not determined.

6. Two separate one-story commercial buildings apparently housed (north to south) the Taco House and Alamo Masa Company, respectively, and faced east toward North Laredo Street, between Zircon Street on the north and Menchaca Street on the south.

7. A two-story commercial building faced east to North Laredo Street and had a sign bearing the name "F. G. Hendricks Co." The building was located in the block between Menchaca Street on the north and Interstate Highway 10 on the south.

With the exception of VIA's property, which was on both sides of San Pedro Creek north of Five Points, the previously described structures were located on the west side of San Pedro Creek. On the east side of the creek, besides Croft Trailer Company, there were several small structures without signs that appeared to be in commercial use on the east side of Camaron Street between the Five 


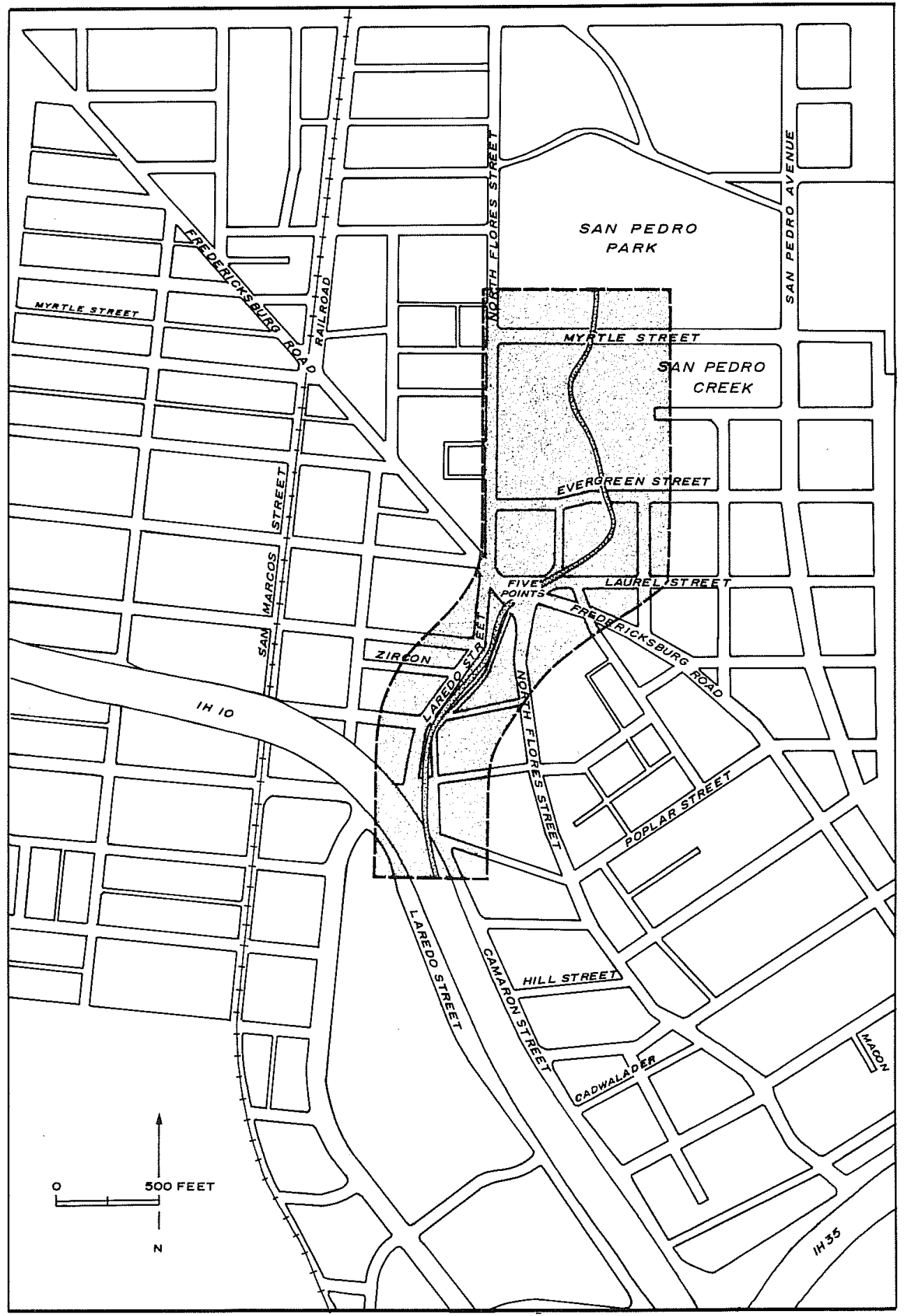

Figure 1. Configuration of Streets and Blocks near the Five Points Intersection in San Antonio, Texas, 1990. Shaded section designates the study area. 


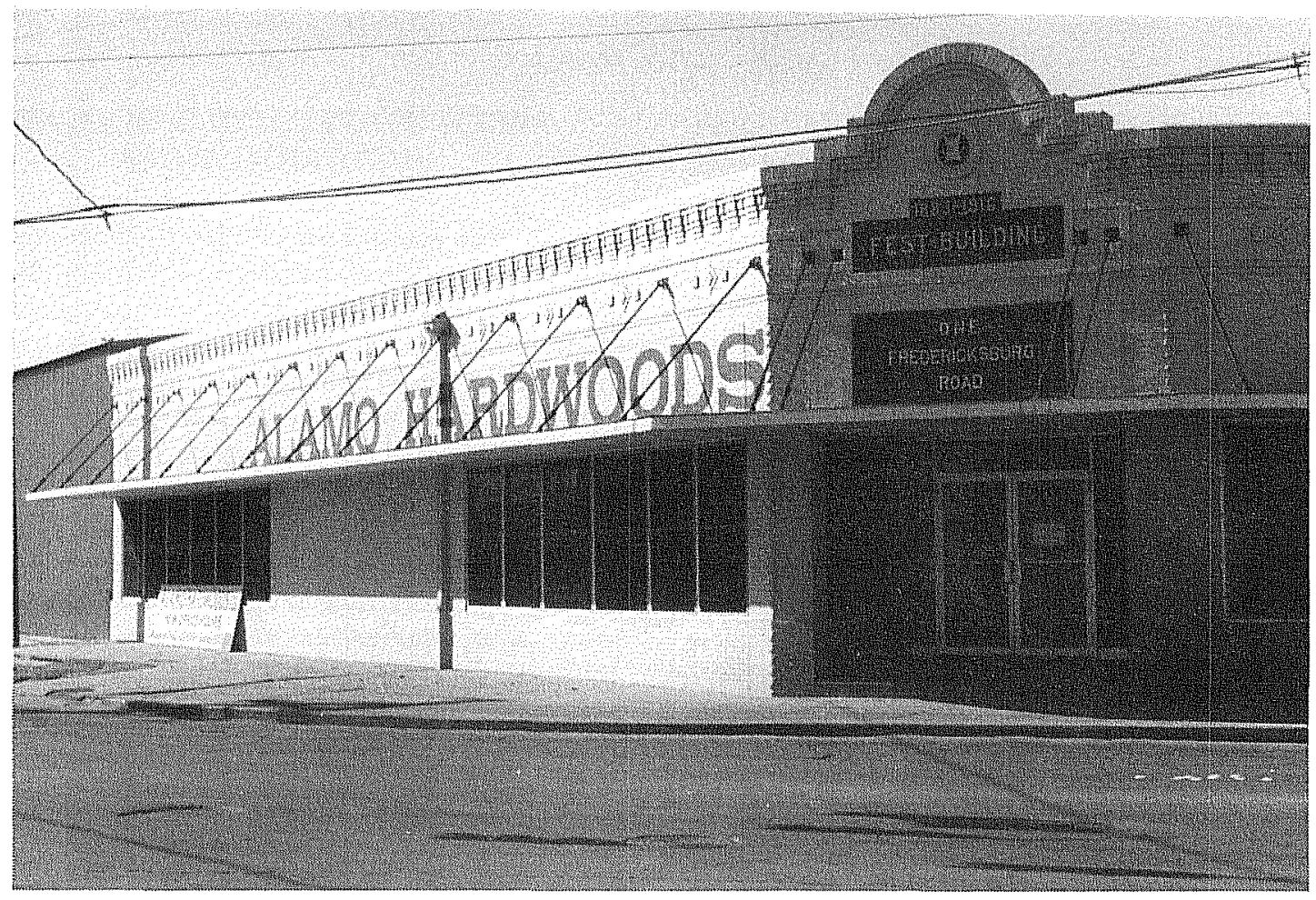

a

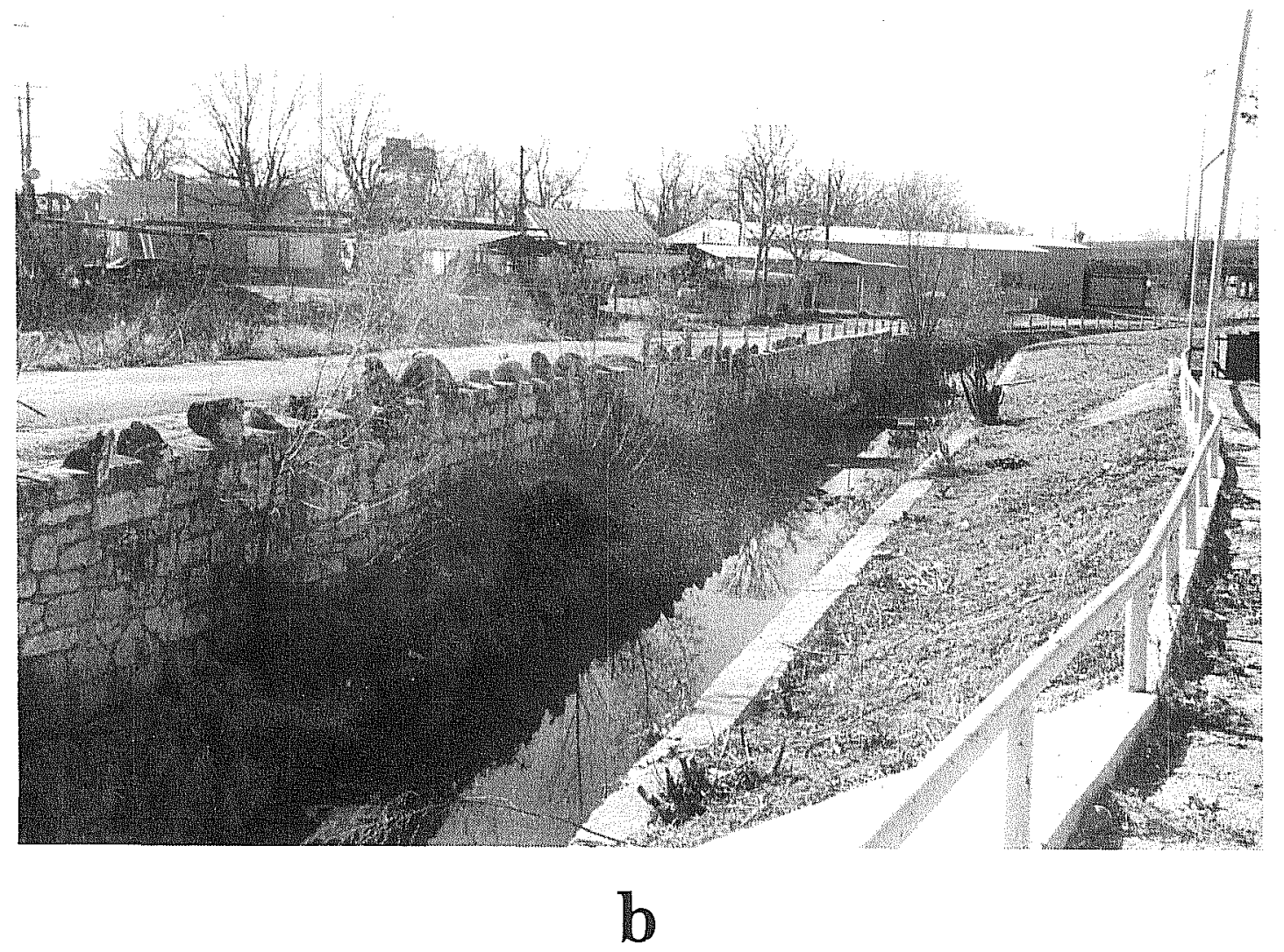

Figure 2. Views of the Five Points Area, 1990. a, Alamo Hardwoods Lumber Building (formerly the Fest Building) located at the Five Points intersection; b, San Pedro Creek from the Five Points intersection facing south toward Interstate Highway 10. 
Points intersection on the north and Interstate Highway 10 on the south. Immediately to the east of Camaron Street toward the south end of the section, stood two small, wood frame dwellings, one of which had access from Camaron Street. The latter were the only visible remnants of residential land usage anywhere along San Pedro Creek within the area to be modified by SARA.

A visual inspection of the structures in the study area revealed that those not in commercial use were vacant. All of the commercial structures were of 20th-century design and construction, with very plain sheet metal or concrete block exteriors, and were utility, warehouse, or office warehouse in style.

South of Five Points, the channel of San Pedro Creek was in reasonably good condition; however, portions of the stone lining were crumbling. The narrow strips of land on both sides of this section of the creek were landscaped with domestic turf and a row of fairly mature trees (Fig. 2,b). Camaron Street abutted the landscaped buffer zone on the east side of the creek, and North Laredo Street adjoined it on the west. These asphalt-surfaced streets ran parallel to the creek from Cypress Street to Five Points. The stone channel lining apparently dates from the early 1940s. An article that appeared in the San Antonio Express (1940) provides additional details about the San Pedro Creek channel:

Authorization to begin work on two WPA projects at a total cost of $\$ 57,503$ was issued by Sterns $S$. Tucker, deputy WPA administrator in Texas. ...

Work on San Pedro Creek will include deepening and widening the channel, paving the creek bed, building a retaining wall and removing obstructions. The landscaping project will include planting of trees and shrubs, removing rocks and other obstructions and extending water lines.

The WPA will provide $\$ 38,544$ for the creek project. ...

\section{PREVIOUS ARCHAEOLOGICAL AND HISTORICAL WORK}

The area around San Pedro Springs has a rich and varied cultural heritage. Unfortunately, no archaeological work has been conducted in this area (Cox 1987:9). However, some noteworthy information on the history of the area has been gathered and published. Perhaps the most comprehensive of the writings on San Pedro Springs are those by Crook (1967) and Janert (1968). Additional important contributions on the area's cultural past include the works of Cox $(1986,1987)$, Fox $(1978,1979)$, and Watson (1982). In the 1986 report, Cox summarizes the history of the San Pedro acequia, and his 1987 monograph contains an account of the history of San Pedro Park. Fox's 1978 and 1979 reports present short area histories, a map of the acequias, and list other structures of possible historical or cultural value that relate to the study area. Watson's (1982) thesis contains information on early suburban residential developments in San Antonio and focuses on the area north of the central urban complex, which includes several of the neighborhoods surrounding San Pedro Park.

Some additional relevant information is in reports by Valdez and Eaton (1979) and Frkuska (1981). Many references to past peoples and events of the San Pedro Springs, San Pedro Park, and San Pedro Creek areas are located in primary sources on the history of San Antonio (Land and Thompson 1885:50-51; Barnes 1910:93-98; Chabot 1936:18, 73; Steinfeldt 1978:199-204). Because so much detailed information is generally available on the history of the area, and because it has been summarized by Cox $(1986,1987)$, only the history directly pertinent to the study area is included in this report.

\section{METHODOLOGY}

The present CAR-UTSA study of the SARA channel improvement area primarily used information available from local archival sources, especially the following:

1. The Bexar Abstract and Title Company's public transaction records are housed at the records plant of the Mossrock Drive office of Stewart Title Company of San Antonio. These are large, hard cover binders containing sets of roster sheets of all transactions publicly recorded for each of the blocks within the city of San Antonio, and in most cases transactions are listed sequentially on the sheets from 1850 to the present. The dates of origin 
for the sheets are not shown, but every line on the roster represents a single event and identifies: (1) the grantor and grantee, mortgagee and mortgagor, plaintiff and defendant, or the deceased and the heirs, depending on the type of transaction; (2) the type, volume, and page number of the public record book where a copy of the deed, will, mortgage or other written instrument relating to the transaction may be found; (3) the date and type of transaction; and (4) the city lot number or numbers involved.

2. San Antonio city directories were available on microfilm or as original directories at the UTSA John Peace Library and the CAR archaeology laboratory, and also at the Daughters of the Republic of Texas Research Library at the Alamo. City directories contain the following: (1) general information about the city of San Antonio; (2) the names, addresses, telephone numbers, ethnicity attributions, occupations, and employers of most individuals; and (3) the names, addresses, types, and advertisements of many businesses. Eight directories were consulted: 1877-1878 (Moody and Morrison 1877), 1881-1882 (Morrison and Fourmy 1881), 1885-1886 (Morrison and Fourmy 1885), 1891 (Johnson and Chapman 1891), 1895-1896 (Appler 1895), 1901-1902 (Appler 1901), 1903-1904 (Appler 1903), and 1927-1928 (Worley 1927).

3. The Sanborn Fire Insurance Company maps of San Antonio are scaled plan drawings, and in most cases are very accurate, showing the locations, sizes, and construction types of the thoroughfares, homes, and municipal and commercial structures within the city. They were compiled or updated every few years, from roughly the late 1870 s to the present. Microfilm copies of the Sanborn maps for the years 1896, 1905, and 1911 are located at the UTSA John Peace Library.

4. Augustus Koch's 1873 and 1886 bird's eye sketch maps of San Antonio are perspective views of the city as it might have appeared from two different arbitrary points in the sky. Although the portrayal of architecture on the sketches is stylized, the locations and configurations, and many detailed features of structures are fairly accurate. Copies of the bird's eye view maps are on file at the CAR archaeology laboratory.

Auxiliary sources, including other maps, documents, and manuscripts, located in the CAR-UTSA files or the UTSA John Peace Library Special Collections, were also consulted. Several in-person interviews with business owners in the channel improvement area were conducted by $H$. Uecker, and the area was examined on foot by Uecker and I. Waynne Cox in early 1990.

It should not be assumed that all of the possible sources of data were exploited. Numerous sources exist which were not examined. For example, the author was informed of several privately owned collections of historical materials so voluminous as to preclude their investigation and documentation within the time and budget constraints of the project.

Several lists were compiled to integrate streets, street numbers, and structures from the Sanborn maps, bird's eye view maps, and from numerous property ownership maps with names of residents, dates of occupancy, and other pertinent facts from the transaction records and the city directories (see Appendix I). All of this information was cross-checked for accuracy. Outline histories of properties, people, families, or businesses were then produced. These histories were integrated into a brief overall social and structural history of the study area. Based on that history, on the remnants of historically significant structures standing in the area in 1990, and on a rough estimate of the potential for preservation of subterranean architectural remnants over time, an overall assessment of the cultural resource potential of the area was formulated.

\section{SELECTIVE HISTORICAL ANALYSIS}

Primarily from patterns of land occupancy and ownership which became evident during the research, the history of the study area may be divided into the following periods: prehistoric aboriginal occupation, historic aboriginal and Spanish colonial occupations, German cultural infusion, land speculation and residential development, and commercialization. In the following subsections, each period is briefly examined.

\section{PREHISTORIC ABORIGINAL OCCUPATION}

Peoples largely of Asiatic origin, but generally referred to as aboriginals, native Americans, American Indians, or ancient Americans, inhabited most of North America for many thousands of years before the 15th century infusion of Europeans to the New World (cf. Hester 1980:131-163; Turner and Hester 1985:46-69). These early pioneers entered North America from Asia via the Bering Strait sometime prior to about 15,000 B.P., probably during a warming period between major episodes of global cooling and glaciation. They gradually spread over all of the Americas, practicing a stone-age hunting and gathering life style. During the last few thousand years, their cultures greatly 
diversified, and their populations flourished. By the early 18th century when the Spanish established missions in Texas, perhaps as many as several hundred Indian groups, each having a fairly distinct linguistic or sociopolitical identity, lived in areas in the southwestern United States, including Texas and northern Mexico (cf. Schuetz 1976:1; Campbell 1979:1, 1988:39).

Many of the Indians continued into the Late Prehistoric and even into the Historic period to engage in nomadic hunting and gathering, following regular subsistence rounds in order to exploit a variety of seasonably available resources. Some groups had begun the routine practice of horticulture or agriculture, and had settled in permanent or nearly permanent villages by about A.D. 500 in Texas. Shortly after the introduction of horses by the Spanish into the American Indian cultures in the 17th century, bison hunting became the way of life for many tribes on the Great Plains, where nomadism continued to be practiced. Two of the Plains tribes, the Apaches and Comanches, are best known for their exploits in Texas, and especially for their raids from the north into the Hill Country near San Antonio.

Sizeable parties of Plains Indians, and groups from local tribes as well, occupied or visited San Pedro Springs throughout much of the Historic period. It is reputed that on unusual occasions, wandering bands of Indians made appearances or camped at the springs even during the last quarter of the 19th century. Along similar lines, Barnes (1910:13, 65-74) described the reluctance of the local Indians to relinquish their territory at San Pedro Springs to the early Spanish settlers. He also includes the account of a rare discovery inside a cave in San Pedro Park found by a city of San Antonio work crew (Barnes 1910:100):

In it [the cave] were found the skeletons of Indians of huge stature, some exceeding seven feet in height. ... Besides these skeletons were found some stone pottery and a number of arrow heads as well as stone spear heads and other relics of a portion of a tribe of an aboriginal race.

During the current on-site examination of San Pedro Park, artifacts were observed, including burned and chipped stones on the ground surface, evidence of Indian occupation around the springs. Indeed, archaeological and historical studies reveal that, before the subjugation of the Indians to Europeans, both temporary and permanent Indian settlements were located within the best water resource areas. The reader interested in more detailed accounts of the lifeways of Texas Indians may consult any of several excellent references, for example, T. R. Hester's (1980) Digging Into South Texas Prehistory or W. W. Newcomb's (1961) The Indians of Texas from Prehistoric To Modern Times.

\section{HISTORIC ABORIGINAL AND SPANISH COLONIAL OCCUPATIONS}

The first Spaniard, if not the first European, to set foot on Texas soil was probably Alvar Núñez Cabeza de Vaca. His well-known expedition in the Caribbean was shipwrecked off the Florida coast in 1528. For about the next six years, he allegedly wandered along the gulf coast, well into Texas, and finally arrived in Mexico City in 1536. By that time, the Spanish had conquered and dominated many of the aboriginal cultures that occupied Mexico, Central America, and a sizeable portion of South America, and had established a foothold of European-style civilization in those areas. During the 16th and 17th centuries, the Spanish extended their empire in the New World gradually northward from Mexico City to just south of the Rio Grande. In 1691, an expedition of Spaniards from Mexico penetrated Texas to what is thought to be San Pedro Springs. In an often-quoted report to the viceroy, explorer Domingo Teran de los Rios states (Hatcher 1932:14):

We marched five leagues over a fine country with broad plains---the most beautiful in New Spain. We camped on the banks of an arroyo, adorned by a great number of trees, cedars, willows, cypresses, osiers, oaks and many other kinds. This I called San Antonio de Padua, because we reached it on his day.

Fray Damian Massanet, also with the 1691 Spanish expedition, is cited by Crook (1967:2) as attesting that they encountered a "very large tribe" of Payaya Indians at that same location. Several more preliminary expeditions into Texas were conducted by the Spanish during the next few decades.

The landing of the Frenchman René Robert Cavelier, Sieur de La Salle on Matagorda Island in 1684 and the subsequent activities of the French in Texas appear to have consolidated the resolve of the Spanish to colonize the region north of the Rio Grande. Thus, by 1718, the Spanish established the 
first noteworthy settlement north of the Rio Grande near San Pedro Springs. The settlement was called San Antonio de Padua, and consisted of a mission and a presidio based on agriculture, employing Indian labor. The San Pedro Springs-San Pedro Creek area was kept in agricultural use by the Spanish as long as they had control of the area. From their settlement base near the springs, they expanded southward along San Pedro Creek and the San Antonio River, obtaining a party of fresh settlers from the Canary Islands in 1731. The Bexar County missions south of the present Alamo were imported during the mid-18th century from what were originally satellite locations in eastern Texas, and the relocation constituted a final impetus for Spanish settlement along the two watersheds.

With the secularization of the missions in $\mathbf{1 7 9 3}$ came the granting of what had previously been mission-controlled lands in Texas to Spanish citizens. The study area was largely if not wholly under the aegis of the early missions. Through the periods of Mexican and Texan independence, the U.S.-Mexican War, and until just prior to the Civil War, most of the land surrounding the section of San Pedro Creek from the springs to Main Plaza continued in agricultural use. Thus, in a broad sense, there were very few changes in land usage in the area over almost a century and a half during this period.

\section{GERMAN CULTURAL INFUSION}

Some changes in land usage began to occur during the second quarter of the 19th century, and can be accurately related to the infusion of German culture to Texas which occurred about that time. It is clear from the history of immigration in Texas that there were also simultaneous infusions of significant numbers of a few other ethnic groups, mostly of northern European origins. The intent here is not to diminish in importance the contributions of any of these other immigrant groups, but to point out the remarkable talents and unusual tenacity of the Germans as settlers, organizers, builders, and entrepreneurs in the study area. The Germans came early and planted deep roots, and their incipient developments formed a core from which much later development evolved.

As early as the 1830s, a few Germans had already migrated to Texas (Lich 1986:6). Substantial German colonization in Texas began in about 1845 with Prince Carl of Solms-Braunfel's founding of New Braunfels (Biesele 1930:119). During the next decade, the German settlements of Fredericksburg and Boerne developed in the Hill Country north and northwest of San Antonio. Contemporaneously, the Germanic population of San Antonio was on the increase and by 1876 , according to the town assessor, totaled 5630 Germans and Alsatians (Fehrenbach 1978:117).

During the time of these early German colonizations in Texas, the San Antonio end of Fredericksburg Road terminated at Five Points, and from that intersection most traffic into San Antonio proceeded south along North Flores Street. Conversely, much of the traffic headed northwest out of the city exited via the North Flores Street-Fredericksburg Road corridor. Consequently, many Germans either owned property, lived, established businesses, or worked along the section of the corridor between San Pedro Springs and Main Plaza. This is substantiated by the fact that German names are associated directly with the area during the period on plat maps, in city directories, and in various other sources consulted.

There are several notable examples of German commercial institutions that were started in the area in the 19th century. John Fest's camp yard, saloon, wagon manufacturing, and dry goods business and Jacob Wohlfarth's saloon, feed store, and dry goods were both located at the Five Points intersection. Also, a biergarten and amusement concession was operated by the Duerler family and later by Frederick Kerble at San Pedro Park. August Santleben ran a freight transfer line from a location at San Pedro Springs from nearly mid-century at least, until the coming of the railroad to San Antonio in 1877, and in 1890 he resided at 688 North Flores Street (Johnson and Chapman 1891:342). Ernst Schaeper and Augustus Wild worked as granite cutters in Frank Teich's quarry and resided at "Fredericksburg road nr N Flores" (Johnson and Chapman 1891:344, 406). Henry Spangler operated a blacksmith shop near the Five Points intersection in the 1890s. Augustus R. Hurley is listed in city directories from the late 1870 s and early 1880 s as a "nurseryman" and "fruit grower," and is shown as residing on the east side of " $n$ Flores first house $n$ of San Pedro creek" (Moody and Morrison 1877:121; Morrison and Fourmy 1881:174).

Some additional surnames (Dietler, Dietsch, Herff, Horst, Jagge, Kaupert, and Maltsberger) that seem to be of Germanic origin are associated with the area as either residents or landholders from the mid-19th century through the early 20 th century. Further details about German influences on area developments are provided in the subsection on commercialization. The reader interested in the founding and development of German settlements around San Antonio, should consult either Biesele (1930) or Lich (1986). 


\section{LAND SPECULATION AND RESIDENTIAL DEVELOPMENT}

During the years immediately prior to and after the Civil War, several tracts of land were obtained by individuals along the northern portion of San Pedro Creek, apparently for short-term holding and resale, or in some cases for conversion to residential subdivisions. Those acquisitions closely presaged a period of suburban development that occurred in the last half of the 19th century north of the central urban district of San Antonio, described in some detail by Watson (1982). Watson (1982:40) correlates the culmination of suburbanization with the opening of the street rail service to the area:

The San Pedro street railway gave impetus for the long-time property owners to subdivide and develop their land, or to sell to ... speculators who did....

Transactions in the Bexar County Deed Records and ownerships shown on plat maps from the time confirm that prominent San Antonio businessmen and politicians, or in some cases parties from the more modest ranks of society, engaged in these manipulations of real estate.

Along the east side of San Pedro Creek just south of Five Points, Patrick Walsh, a local builder and contractor, and two other local entrepreneurs, Henry Fest and Henry Borchers, each subdivided their respective lands into residential parcels during the 1880s. McGraw and Hindes (1987:205) have presented the following information about the Walsh family:

... Casimira de la Concepcion ... married Frank T. Walsh (born on April 19, 1860 in San Antonio), on November 5, 1891. Frank's parents were Patrick and Johanna Sweeney Walsh, who came to Texas from Ireland. Frank was associated with his father in the contracting and construction of railroads in Texas and Mexico.

Concepcion and Frank had seven children: Mary, Anita, Lottie, Bessie, Frank T., Harry J., and Edward.

Patrick's residential subdivision was located between Camaron Street and North Flores Street on the west and east, and roughly between Poplar
Street and Hill Street on the north and south, respectively.

A copy of a Plat of Lots on North Flores and Luna Streets Belonging to Henry Fest, and signed by G. Freisleben (1855) was found during this study. This plat shows a number of small tracts facing the streets south of Luna Street (now Cypress Street), and two much larger tracts running roughly east-west between Camaron Street and North Flores Street labeled "Felipe Luna" and "George White." Data on two other residential subdivisions founded contemporaneously just outside of the study area were also encountered. Both were located between Camaron Street on the west and North Flores Street on the east. One was platted by W. G. Kingsbury and recorded on September 6, 1886, with C. P. Matlack, city engineer (Stewart Title Company 1886). It encompassed the area between Romana Street on the north and Kingsbury Street on the south. The second, that of $\mathrm{R}$. Winslow, was officially platted in July 1890 , and included the area between what are now Cadwalader and Macon Streets (Stewart Title Company 1890). Records indicate that subdivision was also prevalent on the west side of San Pedro Creek just north of Five Points. For example, a plat dated July 1885, divides land owned by Peter Jonas in that area into 17 separate residential-sized tracts (City Engineer's Office 1885). Such examples confirm that entrepreneurship based on land enterprises was an ongoing practice in the area during the last two decades of the 19th century.

On both sides of San Pedro Creek in the study area, several dozen structures apparently of a residential nature are clearly shown on Koch's 1886 bird's eye view sketch map of San Antonio. Both Sanborn Fire Insurance Company maps and city directories indicate that sometime between 1890 and 1895, the section of North Flores Street between Main Plaza and Five Points was replatted and renumbered from 9 to 16 blocks. In the 1891 city directory, Jacob Wohlfarth's store at Five Points is listed at 900 North Flores Street (Johnson and Chapman 1891:435); by 1895 it is shown at 1602 North Flores Street (Appler 1895:610), even though its physical location never changed. The area's rapid growth has been quite properly attributed, in large part, to the impact of the railroad, which reached San Antonio and began local operation by the late 1870s (Chabot 1936:13). Again, Watson (1982:38) attributes the expansion to the impact of the various improvements in local transportation that occurred after about 1878, when the first public mule-drawn streetcars came into service in the study area. Thus, during the last quarter of the 19th century and the first quarter of the 20th century, 
both large-scale and small-scale transportation improvements contributed to the rapid population growth and commercialization of the area between Main Plaza and San Pedro Springs.

\section{COMMERCIALIZATION}

Chabot (1936:13) offers the following data on population growth in San Antonio for the period from 1877 to about 1936:

The rapid growth of San Antonio dates from 1876 [actually 1877 according Schuchard (1951:28)], when the first railway (Sunset Route) entered the city. From 1879-1880 to 1887 , the population increased from 14,894 to 42,570 ; from 1900 to 1910 , the population increased from 53,321 to 96,614 . Today [ca. 1936] the population of San Antonio exceeds two hundred thousand.

Heusinger (1951:28) estimates the 1860 population of San Antonio at only 8235. Schuchard (1951:23, 30, 39, 46) provides the following dates and population figures: in 1870 , over 12,000 ; in $1880,20,550$; in 1890, 37,673; and in $1900,53,321$. These figures clarify and underscore the fact that San Antonio as a whole experienced an almost exponential rate of growth and development during the last one third or so of the 19th century.

Fehrenbach (1978:114-117) provides a cogent explanation of why the railroad meant so much to development:

It is difficult to understand the euphoria the coming of the railroad caused, or the immediate, dramatic changes it made in San Antonio, without realizing the tremendous handicaps placed on the interior by other modes of transportation. San Antonio was far from the sea, without a navigable river. Every amenity, and most of the necessities for life in the region had to be imported out of Europe or the eastern states, usually from New Orleans via Galveston, then carted halfway across Texas by wagon. San Antonio was tenuously attached to civilization by a rutted wagon trail which was impassable in rainy seasons. The cost of goods was simply enormous due to transportation, and many of the artifacts of civilization were not available.

The first line to reach San Antonio, the Sunset Route of the Galveston, Harrisburg \& San Antonio Railway, ran from New Orleans to San Francisco and passed along the east side of San Antonio's central urban complex. By the early 1880s, the International \& Great Northern Railway out of St. Louis that was soon extended to Laredo and into Mexico, passed only a few blocks west of San Pedro Creek and ran parallel to and along what is today San Marcos Street (Land and Thompson 1885:17-18).

Prior to the latter line's inception, the North Flores Street-Five Points locale had been a zone of ingress and egress to San Antonio from very early times. The Spanish in the 18th century dubbed the creek crossing near Five Points as Pasito de los Apaches, obviously alluding to the fact that the Indians used the crossing frequently. A granite marker placed near the southwestern corner of San Pedro Park by the Daughters of the American Revolution bears the following inscription: "King's Hwy., Camino Real, Old San Antonio Rd." A second granite marker erected near the head of San Pedro Springs in 1924 reads: "Pioneer Freighter's Assn., Nolan's Pack Train 1785, Succeeded by Railroad 1883."

Archival records indicate that at least two other freighters operated lines from North Flores Street locations during the last half of the 19th century. The first, the firm of Froboese and Santleben, hauled goods from various points around Texas and from Mexico to a central receiving and mule quartering area located in the 1850 s near San Pedro Springs. According to Thonhoff (1971:22), in January 1866, August Santleben was awarded the contract to carry mail from San Antonio to Eagle Pass and Fort Clark. The second was Charles Zoller \& Co., with headquarters in 1890 at 728 North Flores Street (Johnson and Chapman 1891:463). Thonhoff $(1971: 28,31)$ also notes that by the middle of the 1870 s, several mail lines ran from San Antonio to many nearby communities, including Fredericksburg, and that a number of other coach lines bound for west Texas departed on a regular basis northwest out of San Antonio:

... four horse coaches . . . left San Antonio for El Paso via Boerne [and] Fredericksburg. Early in 1878, C. Bain and Company announced 'an elegant line of four and six horse coaches,' which left their office on 
Alamo Plaza daily except Monday for Leon Springs, Boerne, and Fredericksburg.

North Flores Street is also known to predate San Pedro Avenue by perhaps as much as three or even four decades as the primary route to San Pedro Park from downtown San Antonio. In an account from the book Frontier and Pioneer Recollections of Early Days in San Antonio and West Texas, which apparently related to the year 1867 , Vinton Lee James (1938:122) briefly described the area between the park and the city:

From the corner of Main Avenue and Romana Street to San Pedro Springs was an unbroken mesquite thicket, which extended on both sides of the road, which was lighted by torch lights on high poles placed in the ground.

The road referred to was very likely what is now North Flores Street. Only a little over a decade and a half later, a streetcar rail track line extended "from San Pedro Park, south on Flores Street to the Sunset Railway crossing near South Flores and Alamo streets" (Watson 1982:41). San Pedro Park had been improved to include a large lake, fish ponds featuring exotic varieties of fish, a bear pit, an aviary, various public buildings, and a dance pavilion (Crook 1967:59). In 1987, Anne Fox (personal communication) observed the uncovering of old metal trolley tracks under Flores Street near its intersection with Salinas Street during construction excavations for the rerouting of Martin Street. During investigations for this report, Rick Grimm, librarian at the San Pedro Branch of the San Antonio Public Library, showed H. Uecker remnants of metal tracks that are still in place just south of the library building in San Pedro Park. During the 1890 s and early $1900 \mathrm{~s}$, baseball diamonds, an electric amusement park, and a water slide area were added to the park. By that time, electricity had replaced mules to power the street railway, thus reflecting the ongoing diversification of technology and its applications which became the earmark of the terminal 19th century.

One final aspect of transportation deserves discussion here. From the mid-19th century until well after the railroads came to south Texas, there were numerous cattle drives through San Antonio to northern markets along prescribed trails. The Western Trail, which originated in Brownsville, left San Antonio for Bandera and Kerrville, and then proceeded northward through Oklahoma, Kansas, Colorado or Nebraska, Dakota or Wyoming territories, and terminated in Montana territory (Flanagan 1974:97, 176). Mrs. Jettie McCoy Holleman, a long-time resident of the Five Points area, who was 88 years old when she was interviewed for an article that appeared in The Daily Commercial Recorder on March 23, 1989, related (Lynn 1989):

Cowboys used to herd longhorn cattle down Frederickburg and Blanco roads. One of my sweetest memories is hearing the cowboys sing the cattle to sleep. They played violins and French harps and sang, and the cattle lowed until they went to sleep.

Indeed, the area around Five Points appears to have had a long history involving stock raising and agriculture, which formed a base for the development of related types of small businesses nearby. The agrarian impetus probably began in the early 18th century with the inception of Spanish control of the area. City directories from about the last third of the 19th century list various individuals residing in the area as "stockmen" or "dairymen." For example, George W. Maltsberger is listed in the 1881-1882 city directory as a stockman and dealer (Morrison and Fourmy 1881:197). By 1895, he is designated in the city directory as "shipper of and dealer in fine stock, r 1225 N. Flores" (Appler 1895:406). No improvements are shown on Maltsberger's land, which is located on the east side of San Pedro Creek between the residential subdivisions of Patrick Walsh and Henry Borchers on a plat dated May 2, 1892 (Stewart Title Company 1892). Perhaps Maltsberger had been ranching this land for a considerable time and continued to do so well into the era of residential development in the vicinity.

Several cattlemen with the surname Rodriguez are known to have been landowners in the study area. Jose Maria Rodriguez owned a sizeable tract of land on the east side of the creek near Five Points according to the Friesleben (1855) plat of the area (Fig. 3). City directories from 1877-1878 through 1885-1886 list him as "dairyman," and the 1885-1886 directory has him residing at "cor Laurel, Duffield" (Morrison and Fourmy 1885:269). A man named Juan F. Rodriguez is also listed in the 1895-1896 directory (Appler 1895:499) as "ranchman, r 612 W Evergreen," and a man named John Rodriguez is shown in the 1901-1902 directory as "btdr [bartender] San Pedro Park, r 714 W. Laurel" (Appler 1901:457). Perhaps these latter two Rodriguezes were related to Jose Maria or to the Juan F. Rodriguez, who is also indicated on an 
unnamed and undated plat map of the area between Myrtle Street and Laurel Street as the owner of land near Five Points on the east side of San Pedro Creek (Stewart Title Company n.d.). He is listed in several city directories from 1877-1878 through 1901-1902 as a ranchman and as residing and operating a feed store from a location on Commerce Street between Laredo Street and East Street.

Whereas no hard evidence was encountered in these investigations that would positively categorize the Five Points vicinity as a major locus of cattle raising and processing operations in the San Antonio area, the zone near the intersection seems to have retained a rural agricultural character favorable for such activities well into the latter half of the 19th century. In fact, numerous grocery and meat markets, livestock feed stores, wagon making establishments, camp yards, and a blacksmith shop lined North Flores Street (see Appendix I), and cattle drives departed San Antonio from the immediate area in those times. Also, there are many listings in city directories of occupations for wage earners and small business proprietors who lived in or near the study area and who were directly or indirectly related to the animal husbandry or agricultural industries: gardener, farmer, laborer, teamster, stockman, ranchman, dairyman, butcher, hay dealer, and fruit grower. Even as late as 1927, "Jos" Milmo is indicated in the city directory as residing at 1419 North Flores Street, and his occupation is listed as "rancher" (Worley 1927). His wife, Laura Hickman Milmo, is shown on a plat dated May 2, 1892, as the owner of a tract of land just to the south of the Five Points intersection (Stewart Title Company 1892). This tract was part of Jose Maria Rodriguez' acreage as shown on the early Friesleben (1855) plat of the area (Fig. 3).

With the blossoming of the transportation, construction, recreation and amusement, and retail sales industries in the area in the last quarter of the 19th century some new types of occupational listings appear in the directories for the first time. There is also a noticeable increase in the numbers of persons shown as employed under many of the previously existing categories. Examples of such categories include clerk, bartender, contractor and builder, carpenter, bricklayer, plumber, painter, stonecutter, cabinetmaker, brakeman, coachman, conductor, expressman, street sprinkler driver, beer driver, and salesman. Also, some expansion in the bureaucratic or professional class seems to have occurred during this time. As evidence of this, both qualitative and quantitative changes occur in the directory listings and are reflected under such classifications as real estate agent, attorney, surveyor and engineer, land agent, tax assessor and collector, and travelling salesman and broker.

The data compiled for this report indicate that development in the San Pedro Creek area near Five Points continued to be mainly residential in character throughout approximately the first quarter of the 20th century. Even though less research emphasis was placed on the periods after about 1910 than on the previous eras, from the information obtained on area developments during the first half of the 20th century, it seems reasonable to make the following general observations. The history of the area after about 1930 related almost entirely to the commercial influences present. The

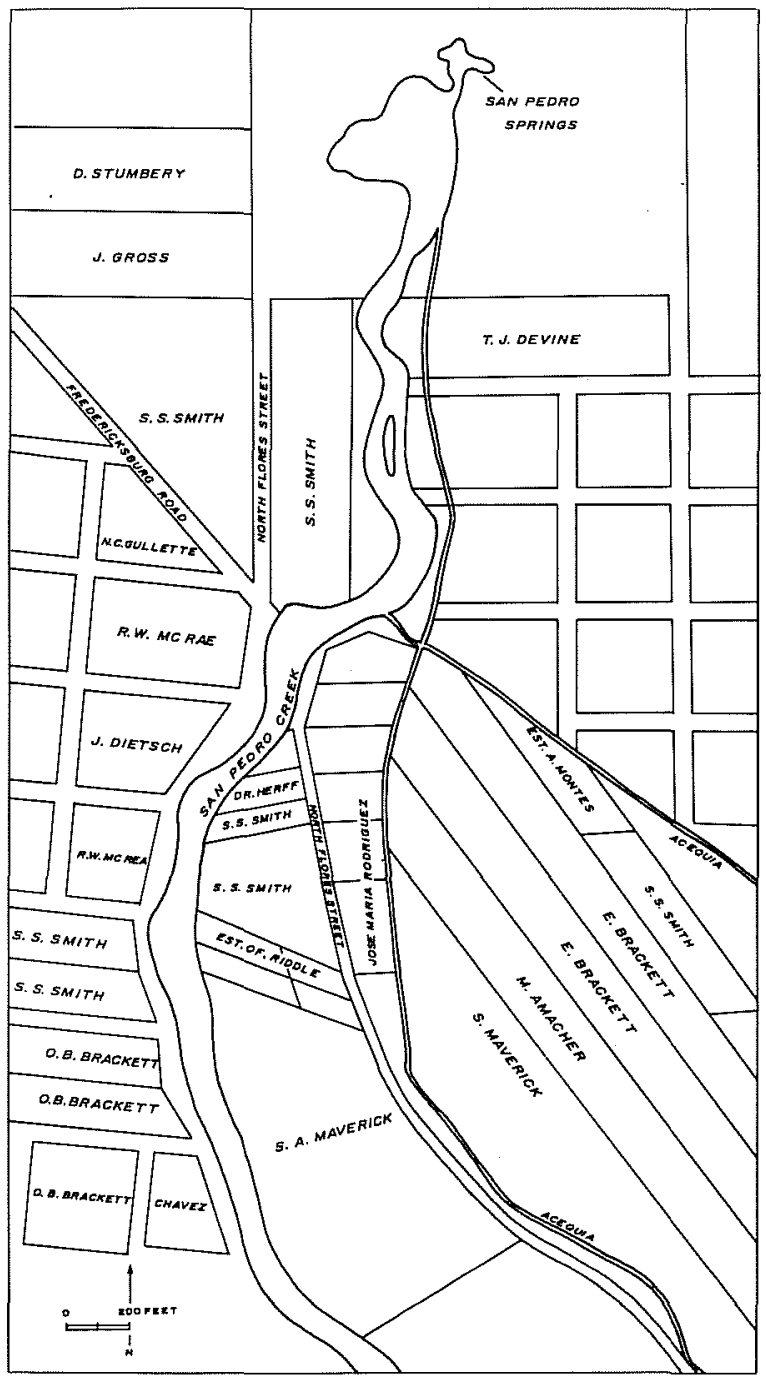

Figure 3. Section of San Pedro Creek and Surrounding Lands Encompassing the Study Area in the Mid-19th Century. Names are property owners. After Friesleben (1855). 
trend toward greater commercialization was reflected in social class structure, land usage, and architectural styles during the second quarter of this century and afterward, recently (1950s through early 1990s) culminating in an industrial pattern of development in the area. The fact that several of the buildings in the area were vacant in early 1990 was very likely related to the general state of overabundance of extant warehouse, office warehouse, and retail space in relation to demand in the San Antonio area at that time.

\section{SUMMARY}

The history of the Five Points-San Pedro Creek area may be characterized as a highly diversified interaction of people and events with impressive time depth. Indeed, the temporal distribution of cultural manifestations within the study area encompasses many thousands of years of more or less continual occupation or utilization by human groups. Including the aboriginal groups, the cultural associations of the south and central Texas-northern Mexico area probably have involved several hundred sociopolitical or ethnically distinct entities. Many of these groups came to the San Pedro Springs-San Pedro Creek area seeking the beautiful natural setting and the plentiful supply of clean, fresh water that once flowed there. It is from the mission and presidio established in the early 1700 s somewhere near the Five Points area that the modern metropolis of San Antonio eventually evolved. Beneath today's veneer of concrete, steel, and asphalt, and the veil of centuries, some important pieces of the puzzle of our past may still lie buried.

\section{CULTURAL RESOURCE POTENTIAL}

The CAR-UTSA investigations concentrated largely on lands immediately adjacent to San Pedro Creek. Only a short distance east of the creek, the San Pedro acequia, last used in the late 19th century or early 20th century, extended north to south through the VIA property between Myrtle and Laurel Streets. Constructed by the Spanish to irrigate fields and orchards in the early to mid-18th century, the acequia originally branched from a point near the source of San Pedro Springs and flowed southward past the Five Points intersection. Several remnants of the historic irrigation ditch have been discovered under the VIA parking lot, the most recent of such finds having been made in 1989, during parking lot construction. Also dating from the Spanish colonial era, the Arocha acequia is reported to have been on the west side of the creek, parallel to North Flores Street; however, recent limited archaeological test excavations by the CAR found no trace of it (Cox 1986).

Some evidence indicates that a few isolated residences were built in the study area during the mid-19th century. For example, an article entitled "Landmark of Civil War Days," alleged that an old home, which apparently was still standing at the corner of North Flores Street and Fredericksburg Road at that time, was built during the Civil War as the residence of Arter Crownover (San Antonio Light 1941). Crownover's parents were members of the party of colonists organized by Moses Austin who left the Carolinas for Texas in 1820. Bexar County archivist John Leal (personal communication) stated that the home was located just north of the Five Points intersection somewhere on the west side of North Flores Street; however, its exact location was not determined during this study. Even though the home itself was razed some time ago, its subterranean remnants may still exist near the Five Points junction.

North of the Five Points intersection, several residential structures were built during the 1880 s or 1890s (Sanborn Map and Publishing Company, Ltd. 1905 , 1911). Most faced on or were closest to Jonas Street (now La Harpe Street), or in some cases North Flores Street. The rear yards of several of these residences extended to the edge of San Pedro Creek and contained a few outbuildings, remnants of which might be encountered during the proposed channel improvements.

No evidence was encountered that indicated portions of past grants or tracts in the area south of Five Points ever abutted the creek, or that any structures were built anywhere near the edge of the banks, with the possible exception of a blacksmith shop at Five Points. Archival sources indicate that Murf's Better Burgers was constructed directly over the site of a blacksmith shop apparently owned and operated by Henry Spangler in the 1890s (Johnson and Chapman 1891:366). The location of the blacksmith shop, as shown on the 1905 Sanborn map (Sanborn Map and Publishing Company, Ltd. 1905), was closer to San Pedro Creek than any other structure within the study area. Most of the other historically significant structures that existed in the area were separated from the creek by a road or alley.

The 1896 Sanborn map of San Antonio does not show whether or not there were any streets or other improvements in the study area by that year (Sanborn Map and Publishing Company, Ltd. 1896). Unfortunately, Koch's (1873) bird's eye view sketch 
map of San Antonio in 1873 does not include the area. Nevertheless, the existence of both Jacob Wohlfarth's and John Fest's commercial establishments at the Five Points intersection is well documented in city directories and other archival sources from the late 19 th and early 20 th centuries.

At the time of the CAR-UTSA study of the area, Rosenberg Bros. Supply Co. and Repete at Pete's Wine-Liquor-Beer, located at the northeast corner of the Five Points intersection, occupied the site of what was originally the Jacob Wohlfarth retail dry goods, feed store, and saloon, built ca. 1884 (see Appendix II). While inspecting the exterior of Repete at Pete's Wine-Liquor-Beer store in early 1990, CAR-UTSA investigators H. Uecker and I. Waynne Cox observed several 19th-century German style, hand-quarried and dressed limestone foundation blocks beneath the modern siding on the north (rear) side of the structure. The Alamo Hardwoods Building, according to owner Wayne Hubinger, was constructed in 1916 by John Fest to replace the original Fest dry goods, saloon, and wagon manufacturing building which dated from ca. 1883. A large black and white print, allegedly made from a photograph of the earlier Fest Building taken in about 1910, hung on the wall inside of Andy's Barber Shop. The barber shop was located within the Alamo Hardwoods Building and was owned by Andrew H. Banda. Banda stated that the print was given to him by one of the members of the Fest family after the dismantling of the structure.

Several references mention the fact that what is now North Flores Street extended as an improved road to San Pedro Springs as early as the 1850 s. The road was there by about 1852 , or at least a short time after Jacob Duerler purchased from the city the land around the springs that later became San Pedro Park. The fact that the creek frontage south of the Five Points intersection was used for streets or alleys for many decades is substantiated by the Sanborn Fire Insurance Company maps from 1905 to the present (cf. Sanborn Map and Publishing Company, Ltd. 1905, 1911), which show Camaron Street adjoining the east bank and North Laredo Street next to the west bank of the creek. As was previously outlined in this report, broad-scale subdivision and residential development of the land immediately adjacent to this street-creek zone had begun at least as early as the last half of the 1880s.

The probability that archaeological work could be used fruitfully to fill in historical details about the area not provided by archival studies was borne out by this study. As an illustration of the potential value of archaeology in this regard, it is only necessary to consider briefly the land ownership indicated by a survey made for the city of San
Antonio by Gustavus Friesleben in 1855 . The map produced from the survey shows roughly two dozen separate tracts along the creek owned by prominent San Antonians of the day (Friesleben 1855; Fig. 3). These owners include such notable citizens as Samuel Maverick, Sam S. Smith, Thomas J. Devine, and Dr. Ferdinand Herff (see Appendix I for more past ownerships of properties). They acted as speculators or investors who purchased large tracts of land and held them undivided, in some cases for several decades, for resale to residential developers. While it seems quite probable that those lands were put to some practical use, for example, perhaps leased for agricultural purposes while they were held, this study found virtually no information from archival sources regarding such uses.

With the possible exception of the Crownover home site, nothing was found during these investigations which would indicate with certainty the existence or the locations of any archaeological sites in the area. However, since the archival study of the area was not exhaustive, it is possible that further work could have revealed the existence of more historic sites. Of course, the question of the existence of prehistoric sites cannot be answered by archival research, and no previous archaeological work is known to have been done in the area. What is generally of concern from an archaeological perspective is the possibility of encountering materials dating from the prehistoric or historic Indian, Spanish colonial, or mid-19th century American occupations of the area. The entire area along San Pedro Creek from San Pedro Springs to Military Plaza was used during all of these occupations (cf. Appendix II; Crook 1967; Janert 1968). Thus, it is possible that archaeological work could be very productive in providing certain details regarding past land usage in this area which might not otherwise be available. Potential for good preservation, especially in the area near the creek south of Five Points, is enhanced by the use of much of the zone for alleys or streets continuously since the mid-19th century. Thus, some of the specific kinds of sites that might be discovered during the channel alterations include remnants of mid-19th century home sites, such as that of the Crownover family, Indian campsites or burned rock middens, and portions of backfilled Spanish colonial acequias. Interestingly, the 1716 site of the first Spanish mission in Texas, originally Mission San Antonio de Padua, later Mission San Antonio de Valero, and finally the Alamo, is thought to be near San Pedro Springs (Chabot 1936:18). It has never been found archaeologically (I. Waynne Cox, personal communication). 


\section{CONCLUSIONS AND RECOMMENDATIONS}

SARA's proposed developments in the San Pedro Creek-Five Points area include rerouting and channeling San Pedro Creek and installing culverts along North Laredo, North Flores, and Myrtle Streets. The lengthy and diverse history of the area as determined by this study mandates that care be taken in anticipating and properly handling any archaeological manifestations that may be impacted by SARA's work. Many of the specific structures which archival evidence shows to have existed in the area, date from the 18th century through the early 20th century periods, and could easily fall within the criteria for the establishment of State of Texas historical landmarks or National Register of Historic Places sites. As was pointed out previously, several landmarks already exist just outside of the proposed impact zone.

With the exception of the Jacob Wohlfarth structure at Five Points, none of the standing structures in the project impact area are of historic importance. However, since it is possible that there are historically significant subterranean cultural remains within the impact area, in order to avoid their inadvertent or casual removal during construction and assure compliance with existing antiquities laws, it is recommended that SARA coordinate archaeological work with its channel improvement and culvert installation procedures. This would, at the least, involve appropriate selective archaeological monitoring of building demolition and subsurface disturbances.

\section{REFERENCES CITED}

Appler, J. A.

1895 General Directory of the City of San Antonio, 1895-1896. San Antonio.

1901 General Directory of the City of San Antonio, 1901-1902. San Antonio.

Barnes, C. M.

1910 Combats and Conquests of Immortal Heroes, Sung in Song and Told in Story. Guessaz and Ferlet Company, San Antonio, Texas.

Biesele, R. L.

1930 The History of the German Settlements in Texas 1831-1861. German Texan Heritage Society, Department of Modern Languages, Southwest Texas State University, San Marcos, Texas.
Campbell, T. N.

1979 Ethnohistoric Notes on Indian Groups Associated with Three Spanish Missions at Guerrero, Coahuila. Center for Archaeological Research, The University of Texas at San Antonio, Archaeology and History of the San Juan Bautista Mission Area, Coahuila and Texas, No. 3.

1988 The Indians of Southern Texas and Northeastern Mexico: Selected Writings of Thomas Nolan Campbell. Published by the Texas Archeological Research Laboratory with the cooperation of the Department of Anthropology the College of Liberal Arts and the Institute of Latin American Studies, The University of Texas at Austin.

Chabot, F. C.

1936 San Antonio and Its Beginnings 1691-1731. Artes Graficas Printing Company, San Antonio.

City Engineer's Office

1855 Copy of a plat on the subdivision made for Peter Jonas, C. P. Matlack, city engineer. Filed in the City Engineer's Office, Main Plaza Building, San Antonio, Texas.

Cox, I. W.

1986 Excavations of Portions of the San Pedro Acequia (41 BX 337) and a Search for the Arocha Acequia, San Antonio, Texas. Center for Archaeological Research, The University of Texas at San Antonio, Archaeological Survey Report 161.

1987 Planning Document (Phase I) for Archaeological Investigations at Proposed Development at San Pedro Park. On file at the Center for Archaeological Research, The University of Texas at San Antonio.

Crook, C. E.

1967 The San Pedro Springs Park, Texas' Oldest Recreation Area. Privately printed, San Antonio.

Fehrenbach, T. R.

1978 The San Antonio Story. Continental Heritage, Inc., Tulsa, Oklahoma.

Flanagan, S.

1974 Trailing the Longhorns a Century Later. Madrona Press, Austin. 
Fox, A. A.

1978 Archaeological Investigations of Portions of the San Pedro and Alazan Acequias in San Antonio, Texas. Center for Archaeological Research, The University of Texas at San Antonio, Archaeological Survey Report 49.

1979 A Survey of Archaeological, Architectural and Historical Sites on the San Antonio River from Olmos Dam to South Alamo Street and on San Pedro Creek from San Pedro Park to Guadalupe Street. Center for Archaeological Research, The University of Texas at San Antonio, Archaeological Survey Report 80.

Friesleben, G.

1855 Plat of Lands on San Pedro Springs Belonging to S. S. Smith. On file in the records plant of Stewart Title Company's Mossrock Drive office, San Antonio, Texas.

1885 Plat of Lots on North Flores and Luna Streets Belonging to Henry Fest, March, 1885. On file in the records plant of Stewart Title Company's Mossrock Drive office, San Antonio, Texas.

Frkuska, A. J., Jr.

1981 Archaeological Investigations at the San Pedro Acequia, San Antonio, Texas. Center for Archaeological Research, The University of Texas at San Antonio, Archaeological Survey Report 103.

Hatcher, M. A., translator

1931 The Expedition of Don Domingo Terán de los Ríos into Texas (1691-1692). Preliminary Studies of the Texas Catholic Historical Society 2(1). Austin.

Hester, T. R.

1980 Digging Into South Texas Prehistory. Corona Publishing Company, San Antonio, Texas.

Heusinger, E. W.

1951 A Chronology of Events in San Antonio. Standard Printing Company, San Antonio.

James, V. L.

1938 Frontier and Pioneer Recollections of Early Days in San Antonio and West Texas. Artes Graficas Press, San Antonio.
Janert, E. K.

1968 San Pedro Springs. Master's thesis on file at the Graduate School of Trinity University, San Antonio, Texas.

Johnson and Chapman

1891 General Directory of the City of San Antonio, 1891. San Antonio.

Koch, A.

1873 Bird's Eye View of the City of San Antonio, Bexar County, Texas, 1873. From the collection of the San Antonio Museum Association. Published by R. H. Holland.

1886 Bird's Eye View of the City of San Antonio, Bexar County, Texas Looking North East, 1886. From the collection of the San Antonio Museum Association. Published by R. H. Holland.

Land and Thompson

1885 Historical and Descriptive Review of the Industries of San Antonio, 1885. Reprinted by Norman Brock, San Antonio, 1977.

Lich, G. E.

1986 The Federal Republic of Germany and Texas, A Sesquicentennial Tribute. Inter Nationes, Bonn, West Germany.

Lynn, $\mathbf{R}$.

1989 Battle of the Alamo II: Texan Fights to Keep Monument in Daughters of the Republic of Texas Research Library. The Daily Commercial Recorder. Published by William Johnson, San Antonio. March 23.

McGraw, A. J. and K. Hindes

1987 Chipped Stone and Adobe: A Cultural Resources Assessment of the Proposed Applewhite Reservoir, Bexar County, Texas. Center for Archaeological Research, The University of Texas at San Antonio, Archaeological Survey Report 163.

Moody and Morrison

1877 Directory of the City of San Antonio, 1877-1878. Galveston.

Morrison and Fourmy

1881 General Directory of the City of San Antonio, 1881-1882. Austin.

1885 General Directory of the City of San Antonio, 1885-1886. Galveston. 
Newcomb, W. W., Jr.

1961 The Indians of Texas from Prehistoric to Modern Times. University of Texas Press, Austin.

San Antonio Express

$1940 \$ 51,392$ Job on San Pedro Creek Approved. May 2.

San Antonio Light

1941 Landmark of Civil War Days. May 4.

Sanborn Map and Publishing Company, Ltd. 1896 Map of San Antonio, Texas. New York.

1905 Map of San Antonio, Texas. New York.

1911 Map of San Antonio, Texas. New York.

Schuchard, E.

1951 100th Anniversary, Pioneer Flour Mills, San Antonio, Texas, 1851-1951. Naylor Printing Company, San Antonio.

Schuetz, M. K.

1976 Indians of the San Antonio Area. In San Antonio in the Eighteenth Century, compiled by the San Antonio Bicentennial Heritage Committee:1-21. Clarke Printing Company, San Antonio.

Steinfeldt, C.

1978 San Antonio Was: Seen Through a Magic Lantern, Views from the Slide Collection of Albert Steves, Sr. San Antonio Museum Association.

Stewart Title Company

1886 Plat of Subdivision of Property on North Flores Street by W. G. Kingsbury, recorded September 6, 1886, C. P. Matlack, city engineer. On file in the records plant of Stewart Title Company's Mossrock Drive office, San Antonio, Texas.
1890 Map of Vance property northside of Macon Street, subdivided by $R$. Winslow, July. On file in the records plant of Stewart Title Company's Mossrock Drive office, San Antonio, Texas.

1892 Unnamed plat map on file in the records plant of Stewart Title Company's Mossrock Drive office, San Antonio, Texas.

n.d. Unnamed and undated plat map of the area between Myrtle Street and Laurel Street, San Antonio, Texas. On file at the records plant of Stewart Title Company's Mossrock Drive office, San Antonio, Texas.

Thonhoff, R. H.

1971 San Antonio Stage Lines 1847-1881. Texas Western Press. The University of Texas at El Paso. Southwestern Studies Monograph 29.

Turner, S. E. and T. R. Hester 1985 A Field Guide to Stone Artifacts of Texas Indians. Texas Monthly Press, Austin.

Valdez, F., Jr. and J. D. Eaton

1979 Preliminary Archaeological Investigations of Part of the San Pedro Acequia, San Antonio, Texas. Center for Archaeological Research, The University of Texas at San Antonio, Archaeological Survey Report 85.

Watson, A. M.

1982 San Antonio on Track: The Suburban and Street Railway Complex through 1933. Masters Thesis, Department of Urban Studies, Trinity University, San Antonio, Texas.

Worley, J. F.

1927 San Antonio City Directory, 1927-1928. San Antonio. 


\section{APPENDIX I \\ BASIC ARCHIVAL DATA FOR THE 1989-1990 CAR-UTSA SAN PEDRO CREEK CHANNEL
IMPROVEMENT PROJECT INVESTIGATIONS}

\section{INTRODUCTION}

The information obtained from selected San Antonio city directories and Sanborn Fire Insurance Company maps related to the San Pedro Creek-Five Points area is grouped on the basis of three different criteria: (1) names of property owners as shown on various mid-19th-century to early 20th-century surveys and plats of the area (Tables 1, 2, and 3); (2) addresses of properties abutting San Pedro Creek as indicated in the city directories and on the Sanborn maps (Table 4), and (3) miscellaneous residents and businesses not in the first two categories, but appearing in the city directories to be located within or very near to the area (Table 5). Since names on some of the documents were occasionally misspelled or in some cases were partly illegible, listings for names that were similar to the ones given on the documents are included. It was often helpful in reconstructing both structural and social histories, or to eliminate confusion between very similar names or situations, to include some listings of relatives, boarders, renters, neighbors, employers, and persons living or working outside of the study area, but except in the case of Table 5, this was done very sparingly.
An effort was made to be as complete and accurate as possible, within the parameters given and the time limitations of the project in gathering the information presented here. Thus, city directories were checked roughly every five years for the period from 1877 to 1903 and for the year 1927 for all names. The records plant of Stewart Title Company's Mossrock Drive office in San Antonio, which houses an extensive collection of 18th-century, 19th-century, and early 20th-century plat and survey maps, was thoroughly searched for maps pertinent to the study area. Most of those found were copied and used in formulating the tables. All of the properties that appeared to be adjacent to San Pedro Creek on the 1896, 1905, and 1911 Sanborn maps within the project area were used as the primary basis for Table 4 . Hopefully this rigorous procedure has helped to produce an accurate picture of the area's history. The tables are designed to be referenced easily by name, occupation, address, type of establishment, or source. Thus, they should augment the work of others performing future research on the area. The exact wording has been retained for each city directory entry presented in Tables $1-5$. This has been done to allow the interested reader an insight into the types of data often encountered when examining archival documents. 
TABLE 1. CITY DIRECTORY DATA ON NAMES FROM FRIESLEBEN PLAT OF 1855

PROPERTY OWNER
REFERENCE

Moody and Morrison 1877:90

Morrison and Fourmy 1881:129

Morrison and Fourmy 1881:129

Morrison and Fourmy 1885:119

Johnson and Chapman 1891:150

Dietsch, J.

Morrison and Fourmy 1881:130

Morrison and Fourmy 1885:120

Johnson and Chapman 1891:151

Appler 1895:236

Appler 1901:211

Gullett, N. C.

Herff, Dr.
Moody and Morrison 1877:116

Morrison and Fourmy 1881:166

\section{CITY DIRECTORY ENTRY}

Devine, Thomas J., attorney, office cor Commerce and Yturri res e s South Flores bet Arsenal and Mill

Devine, Thomas J. (Devine and Crowie, attys.), r. es s Flores, first house south of Arsenal

DEVINE \& SMITH (Thomas J. Devine, William S. Smith, Albert E. Devine), attorneys, office room 7-8 Devine bldg, 26 Soledad

Devine, Thomas J. (Devine \& Smith), r. 520 S. Flores

Devine, Albert E., attorney at law (Devine \& Smith) h 907 San Pedro ave

DEVINE, J. P., real estate, 3 Devine bldg. See adv DEVINE \& SMITH (Albert E. Devine and Wm. S. Smith), attys at law, and 8 Devine bldg

[no J.]

Dietsch, Albert, clk S. C. Bellis (groceries and provisions, 337 e Houston [p. 298]), home

Mrs. T. Dietsch

Dietsch, Mrs. Teresa (wid), r. ws Navarro bet Travis and Pecan

Dietsch, Albert, clk S. C. Bellis, h. Mrs. T. Dietsch

Dietsch, Joseph, blksmith Froboese \& Santleben, h. Mrs. T. Dietsch

Dietsch, Theresa (wid Joseph), r. 319 Navarro

Dietsch, Albert, driver Charles Boelhuawe, h 319

Navarro

Dietsch, Joseph, blacksmith, N Flores nr Obraje, h 319 Navarro

Dietsch, Theresa (wid Joseph), h 319 Navarro

[no J.]

Dietsch, Theresa (wid Joseph), boarding, 621 Navarro

[no J.]

Dietsch, Theresa (wid Joseph), boarding, 621 Navarro

[no listing]

Herff, Ferdinand, sr., physician and surgeon, office at A. Nette's drug store, res s s Houston bet Navarro and Jefferson

Herff, John, physician and surgeon, res w s Losoya bet Houston and Commerce

Herff, Ferdinand sr., physician and surgeon, office A. Nette, r. 308 E. Houston

Herff, John, physician and surgeon, offices Nette (August Nette, druggist, $239 \mathrm{w}$ Commerce [p.297] and A. Dreiss (Adolph Dreiss, druggist, 17 and $19 \mathrm{n}$ Alamo [p. 297]), r. ws Losoya bet e Commerce and Houston 
TABLE 1. (continued)

\section{PROPERTY}

OWNER

Mays, William D.

McRea, R. W.

Morrison and Fourmy 1885:224

Rodriguez, Jose Maria

Moody and Morrison 1877:166

Morrison and Fourmy 1881:236

Morrison and Fourmy 1885:269

Appler 1895:499

Appler 1901:457

Smith, S. S.

Moody and Morrison 1877:179

Morrison and Fourmy 1881:254

\section{CITY DIRECTORY ENTRY}

[no listing]

[no McRea]

McRae, Robert, r. es S. Flores 3d house s of creek

Rodriguez, Jose M., n s of North 9th bet West 7th and 8th

Rodriguez, Jose Marie, dairyman, r. cor San Pedro ditch and Monroe

Rodriguez, Jose Marie, r. ne cor Rivas and Salado

Rodriguez, Jose Marie, dairyman, r. cor Laurel, Duffield

Rodriguez, Jose M, lab, r 714 W Laurel

Rodriguez, Juan F, ranchman, I 612 W Evergreen

[the earlier Jose Marie is no longer listed]

Rodriguez, John, btdr San Pedro Park, r 714 W. Laurel (see Sanborn Map and Publishing Company, Ltd. 1911)

Rodriguez, Juan F., ranchman, r 612 W. Evergreen

Rodriguez, Ramon, btdr Joe Cooley (Cooley's Club, saloon, 233 W Commerce [p. 593], r 612 W. Evergreen

Smith, Samuel S., County Clerk office new Court House, e s Soledad bet Commerce and Houston, res $n$ e cor Laredo and North $2 \mathrm{~d}$

Smith, Sam S., County Clerk, office Court house 16 Soledad, r. ns Obraje between Camaron and Laredo 
TABLE 2. CITY DIRECTORY DATA ON PROPERTY OWNERS ON THE EAST SIDE OF SAN PEDRO CREEK SHOWN ON PLATS OF THE LATE 19TH CENTURY TO EARLY 20TH CENTURY

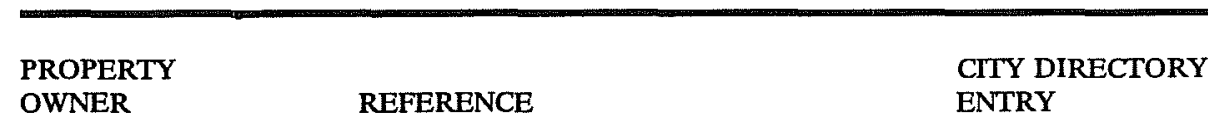

Borchers, Alf.

(Stewart Title

Company n.d.a.)

Borchers, Emma

(Stewart Title

Company n.d.a.)

Borchers (Stewart

Title Company 1877?)/

Bouches, Henry

(Stewart Title

Company 1885)

Dietler, Henry

(Stewart Title

Company n.d.b.)
Appler 1901:151

Johnson and Chapman 1891:107

Appler 1901:151

Moody and Morrison 1877:74

Morrison and Fourmy 1885:107

Johnson and Chapman 1891:107

Appler 1895:73

Moody and Morrison 1877:91

Morrison and Fourmy 1881:130

Morrison and Fourmy 1885:120

Johnson and Chapman 1891:151

Appler 1895:236

Appler 1901:210

Fest (Stewart Title

Company 1887?)
Moody and Morrison 1877:98
Borchers, Alfred, plumber A. H. Shafer (125 W Commerce [p. 591]), r 1320 N. Flores

Borchers, Emma, Miss, h $727 \mathrm{~N}$ Flores

Borchers, Katie, Miss, h 727 N Flores

Borchers, Emma, Miss, $\mathbf{r} 1302$ N. Flores

Borchers, Kate, Miss, clk Bailie's bakery (1013 N. Flores St. [p. 578]), r 1302 N. Flores

Borchers, Henry, vegetable stall city market

Borchers, Henry, r. 727 N. Flores

Borchers, Henry, jr, errand boy C. Schasse, h 727 N Flores Borchers, Henry, sr, h 727 N Flores

Borchers, Josephine, Mrs. (wid Henry), h 727 N Flores

Borchers, Henry, baker Jas Bailie, r 121 Hill

Borchers, Josephine (wid Henry sr), r 1301 N Flores

Borchers, Kate Miss, clk Bailie's bakery, r 1301 N Flores

[no Henry]

Dietler, Franklin, grocer, e s North Flores east of San Pedro creek, res same

Dietler, Catharine (wid), groceries and beer, es North $\mathrm{nr}$ creek, r. same

Dietler, Henry F., driver beer wagon $\mathrm{H}$. Grenet, r. ne cor Matagorda and Victoria

Dietler, Henry F., driver beer wagon Anheuser-Bush Brewing Ass'n. r. 211 Victoria

Dietler, Henry F., driver Lone Star Brewery, h 201 Victoria

Dietler, Henry, driver L S Brewery, r 526 Matagorda

Dietler, Henry, driver L S Brewery, I 922 Camden

Fest, Henry, milk dairyman, res w s North Flores near San Pedro Springs

Fest, John, clk L Kenkel \& Co., bds Simon Fest

Fest, Louis, stone mason, res s s Vilitta bet Alamo and Presa

Fest, Simon, groceries and provisions, w s South Flores near s end of street, res same

Fest, Victor, apprc. harness-maker Francis W. Sibert 
TABLE 2. (continued)

\begin{tabular}{lll}
\hline PROPERTY & REFERENCE & CITY DIRECTORY \\
OWNER & & ENTRY
\end{tabular}

Fest (continued)

Morrison and Fourmy 1881:141

Johnson and Chapman 1891:169

Appler 1895:262

Appler 1895:263

Appler 1901:234

Giorgio, L., Block 3598

(Stewart Title

Company n.d.a., 1892)

Gregg/Gregg Hickman (?) Morrison and Fourmy 1885:156 Block 129, Lot 1

(Stewart Title Company 1892)

Appler 1895:300

Hickman, J. P.

Block 129

(Stewart Title Company 1892)

Moody and Morrison 1877:118

Morrison and Fourmy 1881:168

Morrison and Fourmy 1885:174

Johnson and Chapman 1891:214
Fest, John, clk L. Kunkel \& Co. (wines and liquors, 37 n Flores [p. 305]), r. ws n Flores nr San Pedro Creek

Fest, Henry, alderman at large, h 108 Nogolitos

Fest Hotel, 801 S Flores, T 330, Mrs. Theodore L. Marsh, proprs

Fest, John, dry goods, groceries and saloon, h cor $\mathrm{N}$ Flores and Fredericksburg road, T 254

Fest, Louis, h 14 Hessler alley

Fest, Simon, jr., (Fest's Saloon and Garden), $801 \mathrm{~S}$ Flores, h 904 S Flores, T 372

Fest, Simon, sr., h S Flores between Lover's Lane and Fest Fest's Concert Garden, 31 Fest, Simon Fest prop

Fest, Edward, saloon, 102 Frederickburg Rd, r same Fest, Henry, butcher, 1702 S Flores, r 1708 S Flores Fest, J (wid Louis), r 116 Hessler

Fest, John, groceries, etc, 1723 N Laredo, r 102 Garza

Fest, Louis V, with A Cohen \& Co, r 415 N East

FEST \& MARTY (Mrs S Fest jr, Jos Marty), grocers, 1429

$S$ Flores

Fest, Simon sr, I 119 Simon

Fest, Mary (wid Simon jr) (Fest and Marty), r 1429 N. Flores

Fest, Theresa (wid), r 1339 N Flores

Fest, Edward, saloon, 102 Fredericksburg rd, r 1701 N. Flores

Fest, John, groceries, etc., 1723 N. Laredo, r 102 Garza

Giorgia, Louis (Minnie), grocer 1401 N Laredo

Gregg, Margaret (wid), r. rear 215 Villita

Gregg, A., 1114 W Houston

Hickman, James P., farmer, res w s South Flores near south end of street

Hickman, James P. sr., r. ws s Flores one mile s of Military plaza

HICKMAN, JAMES P., Jr., Propr Southern Hotel, cor Dolorosa, Main and Military Plazas, r. same. See advt Hickman, James P., s., r. Southern Hotel

Hickman, John L., farmer, r. ws S. Flores nr Cevallos

Hickman, James P., jr., hotel keeper (Jones, Hickman \& Timmer), Southern hotel

Hickman, James P., sr., capitalist, h 718 Ave C

Hickman, Laura, Miss, h 718 Ave C

Hickman, Mary, Miss, h 718 Ave C 
TABLE 2. (continued)

\begin{tabular}{|c|c|c|}
\hline PROPERTY & & CITY DIRECTORY \\
\hline OWNER & REFERENCE & ENTRY \\
\hline
\end{tabular}

Hickman

(continued)
Appler 1895:330

Appler 1895:337

Appler 1901:303

Morrison and Fourmy 1885:179

Hovel, Mrs. Mary Louise (Stewart Title Company 1892)

Horst, J. C. (Stewart Title Company n.d.a)

Appler 1895:339

Appler 1901:304

Worley 1927:639

Lincecum(?), W. H. (Stewart Title Company n.d.a.)

Luna, Felipe

(Stewart Title Company 1885)
Morrison and Fourmy 1885:207

Morrison and Fourmy 1881:196

Johnson and Chapman 1891:260

Appler 1895:399

Appler 1895:400

Appler 1901:360
Hickman, Robert, clk auditor's office S. A. \& A. P. Ry, h 718 Ave C

Hickman, Edward, r 216 Obraje

Hickman, Frank, r 239 S Flores

Hickman, James P jr, r Southern hotel

Hickman, J. M., trav slsmn Alamo Iron wks, r Mahncke hotel

Hickman, John L., stockman, r S Flores nr depot

Hickman, Robert L., clk aud off A P R R , r Bexar apartmts

Hickman, Thomas C., lab, r 112 Santos

[no listing]

Horst, J. C., meat market, 301 N Flores, r same

Horst, J. C., stock dealer, r 215 Fest

[no Mrs.]

Hovel, John C., brakeman, r. 715 Ave D

[no Mrs.]

Hovel, John C., condr S P R R, r 1207 Burleson

[no Mrs.]

Hovel, John C., condr S P R R, r 1207 Burleson

Hovel, Mary L., Mrs. (wid Jos C.), h 517 E Park ave

[no W. H.]

Lincecum, Brazos, expressman, r. ns San Luis bt S. Pecos, Leona

Luna, Felipe, r. es Laredo bet Colima and Vera Cruz

Luna, Felipe, h 767 N Flores

Luna, Romaldo, slsmn A. Muguerza, h 767 N Flores

Luna, Felipe de, lab, r 1405 N Flores

Luna, Meliton, job wagon, r 1405 N Flores

Luna, Meliton, lab, $\mathbf{r} 809$ S Frio

Luna, Salvador, lab, r 809 S Frio

Luna, Segunda Mrs., r 809 S Frio

[no Felipe]

Luna, Fred, r 1405 N Flores

Luna, Maria (wid Meliton), r 1405 N. Flores

Luna, Meliton, wks cotton compress, r S Medina, El Paso

Luna, Romaldo, clk A Muguerza (dry goods, 136 S Flores [p. 583]), r. 116 Jonas

Luna, Salvador, wks fire dept, r 101 Luna 
TABLE 2. (continued)

\begin{tabular}{lll}
\hline PROPERTY & & CITY DIRECTORY \\
OWNER & REFERENCE & ENTRY
\end{tabular}

Maltsberger, G. W. (Stewart Title Company 1892)/Maltsberger, T. W. (Stewart Title Company 1887?)

Morrison and Fourmy 1881:197

Morrison and Fourmy 1885:214

Johnson and Chapman 1891:268

Appler 1895:406

Appler 1901:365
Milmo, Laura Hickman

Block 129, Lot 3

(Stewart Title Company

1892)

Naranjo, Mary Hickman Worley 1927:838

Block 129, Lot 2

Rea, Joseph

(SARA n.d.)

Worley 1927:808

Morrison and Fourmy 1885:260

Johnson and Chapman 1891:321

Appler 1895:486

Appler 1901:442

Moody and Morrison 1877

Rodriguez, J. F.

(SARA n.d.)
Maltsberger, George W., stockraiser and dealer, bds Mrs. R. P. Porter

Maltsberger, George W., stockman, r. 715 N. Flores Maltsberger, Alexander P., stockman, h. G. W. Maltsberger Maltsberger, Jonathan B., blksmith, wheelwright, cor N. Flores, San Pedro creek, r. nw cor N. Comal Granado

Maltsberger, George W., stockman, h 715 N Flores

Maltsberger, Jonathan B., lab, h 301 Fredericksburg road

MALTSBERGER, GEORGE W., shipper of and dealer in fine stock, r 1225 N. Flores

Maltsberger, Jonathan B., policeman, r 301 Fredericksburg rd

Maltsberger, Philip, wks S A St Ry, r 1225 N Flores

Maltsberger, V. G., stockman, r 1225 N Flores

Maltsberger, William, wks S A St Ry, r 1225 N Flores

Maltsberger, George W., stockman, r 1225 N. Flores

Maltsberger, J. B., teamster, r 200 Fredericksburg rd

Maltsberger, O., wks L Frank \& Co. (harness and saddlery), 219 W Commerce [p. 587]), r 200 Fredericksburg rd

Milmo, Jos, rancher, r 1419 N Flores

Milmo Laura, Mrs., h 1419 N Flores

Naranjo, Francisco, writer, h 1423 N Flores

Naranjo, Mary (wid Francisco), r 1423 N Flores

Rea, Joseph H., stockman, r. ss Granado nr n city limits

Rea, Joseph H., real estate and Loans, 218 E Houston, h 214 Center

REA, JOSEPH H., furniture, household goods, $206 \mathrm{E}$. Houston, r 339 Porter

[no Joseph]

Rea, Charles, painter, r 1027 S Presa

[6 Johns and 1 Juan, but none with middle initial F. and located within study area]

Morrison and Fourmy 1881:236

Johnson and Chapman 1891:331
Rodriguez, Juan F., feed store, ns w Commerce bet Laredo and East, r. same

Rodriguez, Juan, r. e s Laredo bet Guadalupe and El Paso

Rodriguez, Juan, school teacher, r. ns w Commerce bet San Saba and Pecos

[Also, see Table 1: Rodriguez, Jose Maria]

Rodriguez, G. M., ranchman, h -- Laurel

Rodriguez, Juan F., stockman, 202 Evergreen 
TABLE 2. (continued)

\begin{tabular}{|c|c|c|}
\hline PROPERTY & & CITY DIRECTORY \\
\hline OWNER & REFERENCE & ENTRY \\
\hline
\end{tabular}

\section{Rodriguez}

(continued)

(SARA n.d.)

Walsh (Stewart

Title Company 1892)/

Walsh, P. (Stewart

Title Company 1887?)
Appler 1895:498

Appler 1895:499

Appler 1901:457

Morrison and Fourmy 1881:253

Johnson and Chapman 1891:360

Appler 1895:537

Morrison and Fourmy 1885:320

Johnson and Chapman 1891:396

Appler 1895:590

Appler 1901:542

White, George (Stewart Title Company 1885)
Moody and Morrison 1887:198

Morrison and Fourmy 1881:277
Rodriguez, Antonio, $x 608$ W Cypress

Rodriguez, Jose M., lab, r 714 W Laurel

Rodriguez, Juan F., ranchman, r 612 W. Evergreen

Rodriguez, Severo, stone cutter, r 237 Obraje

Rodriguez, Juan F., ranchman, r. 612 W. Evergreen

Rodriguez, John, Jr. (n.d. Myrtle to Laurel Sts.)

Smith, Miss Alice, dressmaker, rooms 209 Soledad

Smith, Alice, cook J. E. Young, h Pennsylvania ave between W Fifteenth and w Sixteenth, West End

Smith, Alice J. C., Miss, h 1623 Zavala

Smith, Alice, dressmkr, Mrs Diehl, r 805 Starr

Walsh, Edward C., contractor and builder, h P. Walsh

Walsh, Frank, contractor and builder, h. P. Walsh

Walsh, John, foreman Govt printing office, r. 430 Hays bt Cherry, Mesquite

Walsh, Patrick, contractor and builder, r. 693 N. Flores

Walsh, William, carp, h. P. Walsh

Walsh, Edward, Contractor and builder, h 693 N Flores

WALSH, F. T., \& BRO. (Frank T. and John C.), feed store, 19 Ave D, T 484

Walsh, Frank T., feed store (F. T. Walsh \& Bro.), h 695 N Flores

Walsh, J. H., fireman G. H. \& S. \& Ry, h cor Burleson and Olive Walsh, James, h 693 N Flores

Walsh, John C., feed store (F. T. Walsh \& Bro.), h 695 $\mathrm{N}$ Flores

Walsh, John J., bricklayer, h 814 Macon

Walsh, T. P., \& Co. (T. P. Walsh and M. B. Ownby), cornice and iron roofing, 502 Evergreen

Walsh, Patrick, contractor in stone work, h 695 N Flores

Walsh, Thomas P., cornice and iron roofing (T. P. Walsh \& Co.), h 416 Maverick

Walsh, Edward C., contractor, r 1209 N Flores

Walsh, J. V., contractor, r 1209 N Flores

Walsh, John C., contractor, r 1209 N Flores

Walsh, Patrick, contractor, I 1209 N Flores

Walsh, Robert F., butcher, r 433 Lombrano

[no P.]

Walsh, John C., contractor, r 1209 N Flores

White, George, hardware, stoves and tinware, cor Commerce and Presa, res same. See advt.

White, George, jr., tinner, home George White, sr.

White, George, tin, copper and sheet iron worker, 511

Commerce ns Military plaza, r. es Garden bet Mill and Madison

White, George W., tinner G. White, home same 
TABLE 2. (continued)

\begin{tabular}{|c|c|c|}
\hline $\begin{array}{l}\text { PROPERTY } \\
\text { OWNER }\end{array}$ & REFERENCE & $\begin{array}{l}\text { CITY DIRECTORY } \\
\text { ENTRY }\end{array}$ \\
\hline \multirow[t]{5}{*}{$\begin{array}{l}\text { White } \\
\text { (continued) }\end{array}$} & Morrison and Fourmy 1885:327 & $\begin{array}{l}\text { White, George, tin roofer, tin, sheet iron worker, } 611 \text { W. } \\
\text { Commerce, r. } 21 \text { St. Mary's } \\
\text { White, George, tinner, h, George White }\end{array}$ \\
\hline & Johnson and Chapman 1891:405 & $\begin{array}{l}\text { White, George, hardware, tinware, roofing etc., h } 21 \text { St. Mary } \\
\text { White, Mrs. George L., hair goods, h } 23 \text { St. Mary } \\
\text { White, George W., tinner George White, h } 227 \text { Seventh }\end{array}$ \\
\hline & Appler 1895:601 & $\begin{array}{l}\text { White, George, tinner, } 227 \text { St. Mary, r } 225 \text { St Mary } \\
\text { White, George W., mgr L S Cornice Works, r } 1113 \text { E Crockett }\end{array}$ \\
\hline & Appler 1901:552 & $\begin{array}{l}\text { White, George, tinner, } 227 \text { St. Mary, r } 225 \text { St. Mary } \\
\text { White, George W., tinner, r } 1113 \text { E Crockett } \\
\text { White, Julia (wid F), r } 229 \text { Fredericksburg rd }\end{array}$ \\
\hline & Appler 1901:553 & White, Louis, tinner George White, $\mathbf{r}$ same \\
\hline \multirow{6}{*}{$\begin{array}{l}\text { Wohlfarth, G. } \\
\text { (Stewart Title Company } \\
\text { 1892) }\end{array}$} & Moody and Morrison 1877:200 & $\begin{array}{l}\text { [no G.] } \\
\text { Wohlfarth, Jacob, pantryman Menger Hotel }\end{array}$ \\
\hline & Morrison and Fourmy 1881:280 & $\begin{array}{l}\text { [no G.] } \\
\text { Wohlfarth, Jacob, second cook Menger Hotel }\end{array}$ \\
\hline & Morrison and Fourmy 1885:332 & $\begin{array}{l}\text { [no G.] } \\
\text { Wohlfarth, Jacob, groceries, feed, beer, junction } \\
\text { Fredericksburg, Blanco roads, I. same } \\
\text { Wohlfarth, Paul, driver Hugo \& Schmeltzer, h. J. Wohlfarth }\end{array}$ \\
\hline & Johnson and Chapman 1891:411 & $\begin{array}{l}\text { [no G.] } \\
\text { Wohlfarth, Jacob, dry goods, groceries and saloon, } 900 \mathrm{~N} \\
\text { Flores } \\
\text { Wohlfarth, Reinhold, beer driver Anheuser-Bush } \\
\text { Refrigerator, h -- Presa }\end{array}$ \\
\hline & Appler 1895:610 & $\begin{array}{l}\text { Wohlfarth, Augusta (wid John), r } 324 \text { Sharer } \\
\text { Wohlfarth, Jacob, gen'l mdse, 1602 N Flores, r same } \\
\text { Wohlfarth, Paul, driver City Brewery, } 927 \text { Plum } \\
\text { Wohlfarth, Reinhold, driver City Brewery, r } 602 \text { Callaghan ave }\end{array}$ \\
\hline & Appler 1901:562 & $\begin{array}{l}\text { Wohlfarth, Gustav, clk J Wohlfarth, r same } \\
\text { Wohlfarth, Jacob, genl mdse, } 1602 \text { N. Flores, r same }\end{array}$ \\
\hline \multirow[t]{3}{*}{ Woodward, J. P. } & Morrison and Fourmy 1881:281 & $\begin{array}{l}\text { [no J. P.] } \\
\text { Woodward, H. C., route agt G. H. \& S. A. R'y, bds } \\
\text { Menger Hotel }\end{array}$ \\
\hline & Morrison and Fourmy 1885:333 & $\begin{array}{l}\text { [no J. P.] } \\
\text { Woodward, Julia A. (wid C.), r. } 27 \text { Washington }\end{array}$ \\
\hline & Johnson and Chapman 1891:412 & $\begin{array}{l}\text { [no J. P.] } \\
\text { Woodward, C. L., R R emp, h } 225 \text { Ninth } \\
\text { Woodward, David J., slsmn and buyer C. O. McClure, h } \\
\text { cor Macon and Upson } \\
\text { Woodward, Ernest, bill clk Wagner \& Chabot, h } 15 \text { Washington }\end{array}$ \\
\hline
\end{tabular}


TABLE 2. (continued)

\begin{tabular}{|c|c|c|}
\hline $\begin{array}{l}\text { PROPERTY } \\
\text { OWNER }\end{array}$ & REFERENCE & $\begin{array}{l}\text { CITY DIRECTORY } \\
\text { ENTRY }\end{array}$ \\
\hline \multirow[t]{2}{*}{$\begin{array}{l}\text { Woodward } \\
\text { (continued) }\end{array}$} & Appler 1895:613 & $\begin{array}{l}\text { [no J. P.] } \\
\text { Woodward \& Briggs (D. J. Woodward, T. M Briggs), } \\
\text { carriages, } 228 \text { S Flores } \\
\text { Woodward, Charles E., with Woodward and Briggs, r } 304 \\
\text { San Pedro ave } \\
\text { Woodward, D. J. (Woodward \& Briggs), r } 115 \text { Fannin } \\
\text { Woodward, J. S., ins agt, r } 304 \text { San Pedro ave } \\
\text { Woodward, R. P., r } 226 \text { San Pedro ave }\end{array}$ \\
\hline & Appler 1901:565 & $\begin{array}{l}\text { [no J. P.] } \\
\text { Woodward, Dave J (D J Woodward, A H Bock, F A Winerich), } \\
\text { carriages, wagons, horses, 221-225 W Com [?] } \\
\text { Woodward, Raymond C., clk Woodward \& Co., r } 601 \\
\text { Howard } \\
\text { Woodward, Sam, clk Woodward \& Co., r } 1820 \text { Buena Vista }\end{array}$ \\
\hline \multirow{5}{*}{$\begin{array}{l}\text { Wright, Sarah Ann } \\
\text { (Stewart Titie Company } \\
\text { Company n.d.b) }\end{array}$} & Morrison and Fourmy 1885:334 & $\begin{array}{l}\text { [no Sarah Ann, probably because she was wife of James] } \\
\text { Wright, James, stockman, r. } 814 \text { N. Flores }\end{array}$ \\
\hline & Johnson and Chapman 1891:413 & Wright, James, saloon keeper, h cor N San Saba and Chavez \\
\hline & Johnson and Chapman 1891:414 & Wright, James W., saloon, h 306 S Laredo \\
\hline & Appler 1895:614 & Wright, S. A. (wid James), r 1458 N Flores \\
\hline & Appler 1901:566 & $\begin{array}{l}\text { Wright, John E., contractor, r } 721 \text { N Flores } \\
\text { Wright, Sarah A (wid James), r } 1458 \text { N Flores }\end{array}$ \\
\hline
\end{tabular}




\section{PROPERTY}

OWNERS
REFERENCE

Johnson and Chapman 1891:79

Adams, Dr. R S.

(Stewart Title

Company 1928)

Bennett (SARA)

n.d.)

Worley 1927:234

Moody and Morrison 1877:71

Morrison and Fourmy 1881:100

Morrison and Fourmy 1885:78

Johnson and Chapman 1891:99

Johnson and Chapman 1891:100

Cunningham, Mrs.

Edwina Robb

(SARA n.d.)

Del Valle, E. A.

(Stewart Title

Company 1928)

Ellsworth, L. T.

(SARA n.d.)

Garrett, Mrs. M.

(SARA n.d.)

Gibbs, C. C.

(SARA n.d.)
Johnson and Chapman 1891:182

Worley 1927:526

Worley 1927:413

Worley 1927:429

Johnson and Chapman 1891:163

Morrison and Fourmy 1885:151

Morrison and Fourmy 1885:149

Johnson and Chapman 1891
CITY DIRECTORY

ENTRY [no Dr.]

Adams, Richard, h 17 Travis

Adams, Roy S. (Louise), phys H. H. Ogilvie pres Bexar County Medical Society, h 526 E Park ave

Bennett, Jane B., (wid) res w s North Flores [possibly] Bennett, Wharton A. (Bennett \& Lockwood: Wharton A. Bennett and Joseph S. Lockwood, bankers, cor Commerce and Yturri) res n w cor Nueva and Quinta

[probably] Bennett, Samuel W., ass't teller Thornton \& Lockwood's bank, home Mrs. W. A. Bennett

Bennett, Mrs. W. A. (wid), r. nw cor Nueva and Quinta

Bennett, Mary F. (wid W. A.), r. 13 W. Nueva

Bennett, Sam W., h. Mrs. M. F. Bennett

Bennett, Anson G., h San Pedro Place, nr Park ave

Bennett, Charles H., real estate (Burkholder \& Bennett), 39 Alamo Plaza

Bennett, Henry, real estate (Meny \& Bennett), h 427 Ave B

Bennett, Mary F., Mrs. (wid W. A.), h 13 W Nueva, T. 183

Bennett, Sam W., b 13 W Nueva

Cunningham, Jas B. (Edwina), slsmn h 1836 N Flores

Del Valle, Ernesto A. (Sara), h 921 W. Poplar

Del Valle, Evelyn, slsldy, Joske Bros, I 921 W Poplar

Ellsworth, Hallet E., bkpr construction dept S. A. \& A. P. Ry, h 440 Soledad

ELLSWORTH, H. E., hay, grain and salt (Littlefield \& Ellsworth), h 20 Dallas

Ellsworth, Hallet E., deputy U. S. marshall, b 16 Dallas Ellsworth, Riley A., engr I. \& G. N. Ry, h 1050 Hidalgo

[no Mrs.]

Garrett, Warren, real estate (Reeves \& Garrett), h West End

Garrett Field, 1700-20 N Flores

Garrett, Matilda (wid John D.), h 1816 N Flores

Gibbs, Charles C., Gen'l Freight Agt G. H. \& S. A. R'y, r. Converse Station, office Houston, Tex

GIBBS, CHARLES C., Gen'l Freight Agt G. H. \& S. A. Ry System, branch office 285 W. Commerce, r. ns Carson opp Gov't headquarters

[no listing] 
TABLE 3. (continued)

\begin{tabular}{|c|c|c|}
\hline $\begin{array}{l}\text { PROPERTY } \\
\text { OWNERS }\end{array}$ & REFERENCE & $\begin{array}{l}\text { CITY DIRECTORY } \\
\text { ENTRY }\end{array}$ \\
\hline \multirow[t]{2}{*}{ Gibbs (continued) } & Appler 1895:288 & $\begin{array}{l}\text { GIBBS, C. C., land agt S P R R, Alamo Ins } \\
\text { Bldg, r } 905 \text { Mason }\end{array}$ \\
\hline & Appler 1901:256 & $\begin{array}{l}\text { Gibbs, C. C., land agt S P R R, Hicks bldg, r } \\
905 \text { Mason }\end{array}$ \\
\hline \multirow[t]{5}{*}{$\begin{array}{l}\text { Hurley, J. G. } \\
\text { (SARA n.d.) }\end{array}$} & Moody and Morrison 1877:121 & $\begin{array}{l}\text { [no J. G.] } \\
\text { Hurley, Augustus R, nurseryman, res w s } \\
\text { Garden south of city }\end{array}$ \\
\hline & Morrison and Fourmy 1881:174 & $\begin{array}{l}\text { [no J. G.] } \\
\text { Hurley, Augustus R, fruit grower, r. es n Flores } \\
\text { first house n of San Pedro creek }\end{array}$ \\
\hline & Morrison and Fourmy $1855: 182$ & $\begin{array}{l}\text { [no J. G.] } \\
\text { Hurley, Augustus R., clk C. M. Aiken, r. es N. } \\
\text { Flores bt creek San Pedro park } \\
\text { Hurley, Elizabeth, Mrs., r. } 209 \text { Oak }\end{array}$ \\
\hline & Johnson and Chapman 1891:223 & $\begin{array}{l}\text { [no J. G.] } \\
\text { Hurley, Jennie, Mrs. (wid A. R.), h } 1175 \text { N Flores }\end{array}$ \\
\hline & Appler 1895:342 & $\begin{array}{l}\text { [no J. G.] } \\
\text { Hurley, Eliza (wid Guy) (c), r } 118 \text { El Paso } \\
\text { Hurley, Henry (c), lab, r } 118 \text { El Paso }\end{array}$ \\
\hline \multirow[t]{6}{*}{$\begin{array}{l}\text { Jagge, Fritz } \\
\text { Block 212, Lot } 5 \\
\text { (Stewart Title } \\
\text { Company n.d.c) }\end{array}$} & Moody and Morrison 1877:123 & $\begin{array}{l}\text { Jagge, George, meat market, stall } 2 \text { city } \\
\text { market bld'g, res w s Laredo bet Salinas } \\
\text { and North 3d }\end{array}$ \\
\hline & Morrison and Fourmy 1881:177 & $\begin{array}{l}\text { Jagge, Frederick, dairyman, home Mrs. M. Jagge } \\
\text { Jagge, Mrs. Magdalena (wid), r. ns Castro bet } \\
\text { San Marcos and Colorado }\end{array}$ \\
\hline & Morrison and Fourmy 1885:185 & $\begin{array}{l}\text { Jaegge [sic], George, meat market Central } \\
\text { Market, r. Ruiz nr n city limits }\end{array}$ \\
\hline & Johnson and Chapman 1891:227 & $\begin{array}{l}\text { Jagge, George, jr., butcher George Jagge, h } \\
424 \text { N Leona } \\
\text { Jagge, George, sr., Alazan Meat Market, h } \\
424 \text { N Leona }\end{array}$ \\
\hline & Appler 1895:350 & $\begin{array}{l}\text { Jagge, Frederick, r } 642 \text { Garza } \\
\text { Jagge, George jr, wks George Jagge sr, r same } \\
\text { Jagge, George sr (Alazan Meat Market), r } \\
\text { 426 Lake View ave } \\
\text { Jagge, Lina, clk Ben Moke, r } 420 \text { Lake View ave }\end{array}$ \\
\hline & Appler 1901:314 & $\begin{array}{l}\text { Jagge, George jr, wks George Jagge sr, r same } \\
\text { Jagge, George sr (Alazan Meat Market, } 406 \mathrm{~N} \\
\text { Leona [p. 588]), r, } 420 \text { Lake View ave }\end{array}$ \\
\hline $\begin{array}{l}\text { Jagge, Gotfried } \\
\text { (Locke 1889) }\end{array}$ & & [no listing] \\
\hline
\end{tabular}

(Locke 1889) 
TABLE 3. (continued)

\begin{tabular}{lll}
\hline PROPERTY & & CITY DIRECTORY \\
OWNERS & REFERENCE & ENTRY
\end{tabular}

Johnson, Sam

(SARA n.d.)

Kaupert, W. A.

(Stewart Title

Company 1928)

Storbeck, Herman (Locke 1889; Stewart

Title Company n.d.c)

Storbeck, Julia

(Locke 1889; Stewart

Title Company n.d.c)

Storbeck, Robert

(Locke 1889; Stewart

Title Company n.d.c)

Oliver, W. A.

(SARA n.d.]
Moody and Morrison 1877:124

Morrison and Fourmy 1885:188

Johnson and Chapman 1891:231

Appler 1895:356

Appler 1901:319

Morrison and Fourmy 1885:191

Appler 1895:364

Appler 1901:326

Worley 1927:680

Johnson and Chapman 1891:373

Johnson and Chapman 1891:373

Johnson and Chapman 1891:373

Appler 1895:458

Appler 1901:416
Johnson, Sam M., deputy U. S. Custom Collector, office over 4 Soledad, res cor Houston and Navarro

[possibly] JOHNSON, SAM M. (Ogden, Ogden \& Johnson), r. 226 Lexington ave cor Augusta

Johnson, Samuel M., notary public and postmaster, h 226 Lexington ave

Johnson, Samuel M., atty, r 226 Lexington ave

Johnson, Samuel, stockman, r 201 Maverick Grove

[no W. A.]

Kaupert, Lawrence, carp, r. 401 7th cor Ave E

[no W. A.]

Kaupert, Ferdinand, convict guard, r 188 Jonas

[no W. A.]

Kaupert, Ferdinand, lab, r 506 N. Mesquite

Kaupert, Wm A. (Ruth), emp S A Laundry, h 116 La Harpe

[See related entry in Table 5, Storbeck, Robert and Julie Herman]

[See related entry in Table 5, Storbeck, Robert and Julie Herman]

[See related entry in Table 5, Storbeck, Robert and Julie Herman]

[no W. A.]

Oliver, Ann (wid Jackson), r 1015 Lake View ave

Oliver, Britton M, bricklayer, r 708 N San Marcos

Oliver, George F., livestock, 301 W Nueva, r 719 N San Marcos

Oliver, James L. (c), postal clk, r 412 Live Oak Oliver, Junius W. (Southern Brokerage Co) r, 825 Willow

[no W. A.]

Oliver, W. S., bkpr C H Dean Co. (hardware, 228 S Flores [p. 587]; buggies, wagons, hardware, etc. [adv't, back cover]), r 818 Ave D

[no listing]

Richey, C. L

(Stewart Title

Company n.d.c) 
TABLE 3. (continued)

PROPERTY

OWNERS

Richey, Julia

(Locke 1889)

Ross, Jas.

(SARA n.d.)

Tafolla, Fred C.

(Stewart Title

Company 1928)

Thornton

(SARA n.d.)

Moody and Morrison 1877:187

Morrison and Fourmy 1881:264
CITY DIRECTORY

ENTRY

[no listing]

Ross, James W., condr S A St Ry, r 1126 Grayson

Ross, J. D., city slsmn D Talerico (commission merchants, 101 Military Plaza. General. [p. 582]), r 311 San Peđro ave

Ross, James W, teamster, r 101 Vinton

[no listings found]

[probably] Thornton, James T., banker n e cor Commerce and St. Mary, res w s Washington bet Arsenal and Turner

Thornton, James T. (Thornton and Lockwood), r. ns Washington bet Turner and Beauregard

[or even more probably] Thornton and Lockwood (James

T. Thornton, Joseph S. Lockwood), bankers and exchange dealers, $258 \mathrm{~W}$. Commerce cor Yturri. See adv't 


\section{TABLE 4. ADDRESSES OF PROPERTIES ABUTTING SAN PEDRO CREEK FROM SANBORN INSURANCE MAPS}

\begin{tabular}{lll}
\hline ADDRESS & PROPERTY & REFERENCE \\
\hline
\end{tabular}

\section{CAMERON STREET}

[Note: 4 structures are shown without ađdresses in 1904 (Sanbom Map and Publishing Company, Ltd. 1904) on 2 lots that face the part of Cameron Street north of Luna Street (today's West Cypress Street); they include a 1 story dwelling with composition roof, all on the first lot, and a third 1 story dwelling with composition roof on the second lot]

\section{Camaron Street \\ 1338 Camaron Street [also shown as 1026, $1028,1030,1032$, and 1048 West Poplar(?) Street]}

1 story dwelling with composition roof (Sanbom Map and Publishing Company, Lud. 1911) Ltd. 1911)
4 mutually adjoining 1 story tenements (Sanbom Map and Publishing Company,

Appler 1903
Worley 1927
Appler 1903
Worley 1927:548

Worley 1927:1408

Worley 1927:953

Worley 1927:520

1 story dwelling with metal roof (Sanbom Map and Publishing Company,

1340 Camaron Street [also shown as 1049 West Poplar(?) Street]

1344 Camaron Street

1346 Camaron Street

1348 Camaron Street [also shown as 134 Luna Street (today's West Cypress Street)]

1400 Camaron Street Street (today's West Cypress Street)]
Ltd. 1911)

1 story dwelling with both metal and composition roof; 1 story building [storage shed?] at rear with metal roof (Sanbom Map and Publishing Company, Ltd. 1911)

1 story dwelling with composition roof; 1 story building [storage shed] at rear with composition roof (Sanborn Map and Publishing Company, Ltd. 1911)

unimproved

1 story dwelling ["from plans"] with metal Ltd. 1911)
Appler 1903

Worley 1927

Appler 1903

Worley 1927

Appler 1903

[not listed]

Worley 1927

[not listed]

Appler 1903

[not listed]

Worley 1927

[not listed]

Appler 1903

[not listed

Worley 1927

[not listed] 
TABLE 4. (continued)

$\begin{array}{lll}\text { ADDRESS } & \text { PROPERTY REFERENCE } & \text { CITY DIRECTORY ENTRY }\end{array}$

\section{NORTH FLORES STREET}

[NOTE: In 1911, along the east side of North Flores Street between 1622 North Flores Street and Myrtle Street there are at least 3 separate tracts of land improved as follows: the first tract shown north of 1622 North Flores Street contains 8 to 9 separate but adjoining buildings, all 1 story except for one 2 story and some with composition, others with metal roofs, including an "auto ho" and "servants"; the second tract contains a 2 story outbuilding with composition roof, and the third tract contains the improvements previously noted at 820 Myrtle Street]

1430 North Flores Street [does not front directly on creek]

2.5 story dwelling with composition roof and 1 unlabeled outbuilding (Sanborm Map and Publishing Company, Ltd. 1911)

Worley 1927:1044

Appler 1903:245

2 story dwelling with composition roof and 1 unlabeled outbuilding (Sanborm Map

Publishing Company, Ltd. 1911)

Street [does not front directly on creek]

1450 North Flores Street

Worley 1927:1008

Appler 1903:207

\author{
Appler 1903 \\ Worley 1927:469
}

1 story dwelling with both composition and metal roof (Sanborn Map and Publishing Company, Ltd. 1896, 1911) vacant

Escudro, Maria, Mrs., h $1430 \mathrm{~N}$ Flores

Staley, Frank(Ruby), sismn Fehr Baking Co., h (2) 1430 N Flores

Hensley, Frank A, planing mill, 1436 N Flores, I same

Worley 1927:1162

Appler 1903:112

Black, Joseph, lab, r 1452 N Flores

Worley 1927:488
Select Auto Parts Co., G. N. Dexter, prop, $1436 \mathrm{~N}$ Flores

Gandine, Herman, lab, r $1450 \mathrm{~N}$ Flores

WOODIAWN FURNIIURE CO. (F. W. and Oscar Brown), 1450 N Flores, Tel Cr 739 across from 1450

North Flores Street on the west side of North Flores Street but just east of the creek [no address shown]

1452 North Flores Street

diagonally across the street to the far northwest of $\mathbf{1 4 5 2}$ North Flores Street and situated where North Flores and North Laredo Streets met and roughly in the center of what is today the the Five Points intersection [no address shown] metal roof (Sanbom Map and Publishing Company, Ltd. 1896); 1 story cleaning with both composition and metal roof (Sanborm Map and Publishing Company, Ltd. 1911)

1 story blacksmith shop with composition roof (Sanborn Map and Publishing Company, Ltd. 1896) [by 1911, it is not shown (Sanborm Map and Publishing Company, Ltd. 1911), and the place where it was located in 1896 is part of one of the streets (probably North Flores Street) converging at the Five Points intersection]

1 story dwelling with both composition and

1 story warehouse with metal roof and 1 story outbuilding with metal roof (Sanbom Map and Publishing Company, Ltd. 1896); [by 1911, nothing is shown in this area (Sanborn Map and Publishing Company, Ltd. 1911), and the 1896 location is part of one of the streets (probably North Flores Street) converging at the Five Points intersection] 
TABLE 4. (continued)

\begin{tabular}{|c|c|c|c|}
\hline ADDRESS & PROPERTY & REFERENCE & CITY DIRECTORY ENTRY \\
\hline \multirow[t]{2}{*}{$\begin{array}{l}1456 \text { North Flores } \\
\text { Street }\end{array}$} & $\begin{array}{l}1 \text { story dwelling with composition roof; } 1 \text { story } \\
\text { building [storage shed?] at rear with composition } \\
\text { roof }\end{array}$ & $\begin{array}{l}\text { Appler } 1903 \\
\text { Worley } 1927: 488\end{array}$ & $\begin{array}{l}\text { [not listed] } \\
\text { Five Point Filling Station (O. H. } \\
\text { Gloor), } 1456 \text { N Flores }\end{array}$ \\
\hline & & Worley 1927:545 & $\begin{array}{l}\text { Gloor, Otto H. (Emma), prop, } \\
\text { Five Point Filling Sta, h rear } 1456 \\
\text { N Flores }\end{array}$ \\
\hline \multirow[t]{2}{*}{$\begin{array}{l}1458 \text { North Flores } \\
\text { Street }\end{array}$} & $\begin{array}{l}1 \text { story dwelling with both metal and composition } \\
\text { roof; } 1 \text { story building [storage] at rear with } \\
\text { composition roof }\end{array}$ & Appler 1903 & $\begin{array}{l}\text { Wright, Sarah A (wid James), } \\
\text { [blue book at rear of directory } \\
\text { shows her as "(h)," which means } \\
\text { homestead] }\end{array}$ \\
\hline & & Worley 1927 & [not listed] \\
\hline $\begin{array}{l}1602 \text { North Flores } \\
\text { Street [northeast } \\
\text { corner of North } \\
\text { Flores and West } \\
\text { Laurel Streets] }\end{array}$ & $\begin{array}{l}2 \text { story store building with metal roof and } \\
\text { attached } 1 \text { story dwelling with metal roof; } \\
\text { also } 5 \text { detached outbuildings, } 2 \text { with metal } \\
\text { roof and } 3 \text { with composition roof (Sanbom Map } \\
\text { and Publishing Company, Ltd. 1896); rear of } \\
\text { property nearest San Pedro Creek is shown } \\
\text { as } 101 \text { and } 103 \text { Jonas Street, and } 2 \text { of } 5 \\
\text { structures shown as nonresidential outbuildings } \\
\text { on the } 1896 \text { map are shown as } 101.5 \text { and } 103.5 \\
\text { (labeled "ST'GE") Jonas Street; also what was } \\
\text { previously (1896) shown as a } 1 \text { story dwelling } \\
\text { with metal roof attached to the store is shown } \\
\text { as a partial } 2 \text { story grain storage (Sanborn } \\
\text { Map and Publishing Company, } L \downarrow d .1911 \text { ) }\end{array}$ & Appler 1903:593 & $\begin{array}{l}\text { WOHLFARTH, JACOB, genl } \\
\text { mdse, } 1602 \text { N Flores, r same } \\
\text { [not listed; however, John } \\
\text { Fest is shown at } 1608 \text { North } \\
\text { Flores Street] }\end{array}$ \\
\hline \multicolumn{4}{|l|}{ JONAS STREET } \\
\hline 100 Jonas Street & $\begin{array}{l}\text { unimproved (Sanbom Map and Publishing } \\
\text { Company, Ltd. 1911) }\end{array}$ & $\begin{array}{l}\text { Appler } 1903 \\
\text { Worley } 1927\end{array}$ & $\begin{array}{l}\text { [not listed] } \\
\text { [not listed] }\end{array}$ \\
\hline 101 Jonas Street & $\begin{array}{l}\text { [see entry for } 1602 \text { North Flores Street } \\
\text { (Sanbom Map and Publishing Company, } \\
\text { Ltd. 1911)] }\end{array}$ & $\begin{array}{l}\text { Appler } 1903 \\
\text { Worley } 1927\end{array}$ & $\begin{array}{l}\text { [not listed] } \\
\text { [not listed] }\end{array}$ \\
\hline 101.5 Jonas Street & $\begin{array}{l}\text { [see entry for } 1602 \text { North Flores Street } \\
\text { (Sanborn Map and Publishing Company, } \\
\text { Ldd. 1911)] }\end{array}$ & $\begin{array}{l}\text { Appler } 1903 \\
\text { Worley } 1927\end{array}$ & $\begin{array}{l}\text { [not listed] } \\
\text { [not listed] }\end{array}$ \\
\hline 103 Jonas Street & $\begin{array}{l}\text { [see entry for } 1602 \text { North Flores Street } \\
\text { (Sanborn Map and Publishing Company, } \\
\text { Ltd. 1911)] }\end{array}$ & $\begin{array}{l}\text { Appler } 1903 \\
\text { Worley } 1927\end{array}$ & $\begin{array}{l}\text { [not listed] } \\
\text { [not listed] }\end{array}$ \\
\hline 103.5 Jonas Street & $\begin{array}{l}\text { [see entry for } 1602 \text { North Flores Street } \\
\text { (Sanborn Map and Publishing Company, } \\
\text { Lid. 1911)] }\end{array}$ & $\begin{array}{l}\text { Appler } 1903 \\
\text { Worley } 1927\end{array}$ & $\begin{array}{l}\text { [not listed] } \\
\text { [not listed] }\end{array}$ \\
\hline
\end{tabular}


TABLE 4. (continued)

\begin{tabular}{|c|c|c|c|}
\hline ADDRESS & PROPERTY & REFERENCE & CITY DIRECTORY ENTRY \\
\hline 108 Jonas Street & $\begin{array}{l}1 \text { story dwelling with composition roof and } \\
1 \text { story outbuilding with composition roof } \\
\text { (Sanborm Map and Publishing Company, } \\
\text { Ltd. 1911) }\end{array}$ & $\begin{array}{l}\text { Appler 1903:473 } \\
\text { Worley } 1927\end{array}$ & $\begin{array}{l}\text { Walker, John R, lab, r } 108 \text { Jonas } \\
\text { [not listed] }\end{array}$ \\
\hline 109 Jonas Street & $\begin{array}{l}\text { [not shown on Sanbom Map and Publishing } \\
\text { Company, Ltd. }(1896,1911) \text { maps] }\end{array}$ & Appler 1903:188 & $\begin{array}{l}\text { Espitia, Manuel, stockman, r } 109 \\
\text { Jonas }\end{array}$ \\
\hline $\begin{array}{l}110 \text { Jonas Street } \\
\text { [faces on alleyway(?) } \\
\text { running east-west off } \\
\text { of Jonas Street to the } \\
\text { creek] }\end{array}$ & $\begin{array}{l}1 \text { story dwelling with composition and } \\
\text { metal roof (Sanbom Map and Publishing } \\
\text { Company, Ltd. 1911) }\end{array}$ & $\begin{array}{l}\text { Appler } 1903 \\
\text { Worley } 1927\end{array}$ & $\begin{array}{l}\text { [not listed] } \\
\text { [not listed] }\end{array}$ \\
\hline $\begin{array}{l}112 \text { Jonas Street } \\
\text { [located near creek off } \\
\text { alleyway running east- } \\
\text { west between Jonas } \\
\text { Street and creek] }\end{array}$ & $\begin{array}{l}1 \text { story dwelling with metal and } \\
\text { composition roof and associated } \\
1 \text { story outbuilding with } \\
\text { composition roof (Sanborn Map } \\
\text { and Publishing Company, Ltd. } \\
\text { 1911) }\end{array}$ & $\begin{array}{l}\text { Appler } 1903 \\
\text { Worley } 1927\end{array}$ & $\begin{array}{l}\text { [not listed] } \\
\text { [not listed] }\end{array}$ \\
\hline 114 Jonas Street & $\begin{array}{l}1 \text { story dwelling [probable one- } \\
\text { half of duplex] with composition } \\
\text { roof abutting identical structure } \\
\text { labeled as } 116 \text { Jonas Street } \\
\text { (Sanbom Map and Publishing Company, } \\
\text { Ltd. 1911) }\end{array}$ & $\begin{array}{l}\text { Appler 1903:215 } \\
\text { Worley } 1927\end{array}$ & $\begin{array}{l}\text { Gibson, Alfred } F \text {, night } \\
\text { watchman, Palace Stable, } \\
\text { r } 114 \text { Jonas } \\
\text { [not listed] }\end{array}$ \\
\hline 116 Jonas Street & [see 114 Jonas Street] & $\begin{array}{l}\text { Appler 1903:307 } \\
\text { Worley } 1927\end{array}$ & $\begin{array}{l}\text { Luna, Romaldo, clk, } \\
\text { r } 116 \text { Jonas } \\
\text { [not listed] }\end{array}$ \\
\hline $\begin{array}{l}116.5 \text { Jonas Street } \\
\text { [could be ascribed to } \\
\text { either alleyway running } \\
\text { east-west between Jonas } \\
\text { Street and the creek, as } \\
\text { at rear of } 110 \text { Jonas } \\
\text { Street or possibly to } \\
\text { the rear of } 116 \text { Jonas } \\
\text { Street] }\end{array}$ & $\begin{array}{l}1 \text { story dwelling with metal roof } \\
\text { and nearby } 1 \text { story outbuilding with } \\
\text { composition roof (Sanbom Map and } \\
\text { Publishing Company, Ltd. 1911) }\end{array}$ & $\begin{array}{l}\text { Appler } 1903 \\
\text { Worley } 1927\end{array}$ & $\begin{array}{l}\text { [not listed] } \\
\text { [not listed] }\end{array}$ \\
\hline 118 Jonas Street & 1 story dwelling with metal roof & Appler 1903:100 & $\begin{array}{l}\text { Barefield, Maria (c), } \\
\text { r } 118 \text { Jonas }\end{array}$ \\
\hline & & Worley 1927 & [not listed] \\
\hline
\end{tabular}


TABLE 4. (continued)

\section{NORTH LAREDO STREET}

[NOTE: 1309-1323 (inclusive) North Laredo Street are all located within what was shown on the map as a single unimproved tract of land (Sanbom Map and Publishing Company, Ltd. 1904)]

1309 North Laredo 1 story dwelling with composition roof

1311 North Laredo Street

1313 North Laredo Street

1315 North Laredo Street

1315.5 North Laredo Street

1317 North Laredo Street

1321 and 1323 North Laredo Street [slightly out of study area]
1 story dwelling with composition roof located on the same tract with dwelling shown at 1313 North Laredo Street (Sanborn Map and Publishing Company, Ltd. 1911)
1 story dwelling with composition roof located on the same tract with dwelling shown at 1311 North Laredo Street (Sanbom Map and Publishing Company, Ltd. 1911)

1 story dwelling with composition roof (Sanborn Map and Publishing

outbuilding(?) with metal roof (Sanborn Map and Publishing Company, Ltd. 1911)

1 story dwelling with metal and composition roof (Sanborn Map and Publishing Company, Ltd. 1911)

1 story store building with metal roof [not shown on 1904 map (Sanborn Map and Publishing Company, Ltd. 1904)]; also shown as as 100 Rivas Street (Sanbom Map and Publishing Company, Ldd. 1911) Company, Ldd. 1911)

\begin{tabular}{|c|c|}
\hline Appler 1903 & [not listed] \\
\hline Worley 1927 & [not listed[ \\
\hline Appler 1903 & [not listed] \\
\hline Worley 1927:275 & $\begin{array}{l}\text { Barcelona, Benj (Carmen), } \\
\text { blksmth, } 1311 \text { N Laredo, } \\
\text { h } 324 \text { N Pinto }\end{array}$ \\
\hline Worley $1927: 322$ & $\begin{array}{l}\text { Brook, Paul (Mary), h } 5 \text { rear } \\
1311 \text { N Laredo }\end{array}$ \\
\hline Worley 1927:534 & $\begin{array}{l}\text { Gaston, Jessie, h (2) rear } \\
1311 \text { N Salado [Laredo?] }\end{array}$ \\
\hline Worley 1927:536 & $\begin{array}{l}\text { George, Alex, h } 3 \text { rear } \\
1311 \text { N Laredo }\end{array}$ \\
\hline Worley 1927:567 & $\begin{array}{l}\text { Green, Minnie, h (1) rear } \\
1311 \text { N Laredo }\end{array}$ \\
\hline Worley 1927:603 & $\begin{array}{l}\text { Hawkins, Henry, h } 4 \text { rear } \\
1311 \text { N Laredo }\end{array}$ \\
\hline Appler 1903 & [not listed] \\
\hline Worley 1927 & [not listed] \\
\hline Appler 1903 & [not listed] \\
\hline Worley 1927 & [not listed] \\
\hline Appler 1903 & [not listed] \\
\hline Worley 1927 & [not listed] \\
\hline Appler 1903 & [not listed] \\
\hline Worley 1927 & [not listed] \\
\hline Appler 1903 & [not listed] \\
\hline Worley 1927 & [not listed] \\
\hline
\end{tabular}


TABLE 4. (continued)

\begin{tabular}{|c|c|c|c|}
\hline ADDRESS & PROPERTY & REFERENCE & CITY DIRECTORY ENTRY \\
\hline $\begin{array}{l}1401 \text { North Laredo } \\
\text { Street [corner North } \\
\text { Laredo and Garza } \\
\text { Streets] }\end{array}$ & $\begin{array}{l}1 \text { story store with composition and } \\
\text { metal roof [outbuilding at rear is shown } \\
\text { as } 1 \text { story dwelling with composition roof } \\
\text { with address of } 105 \text { Rivas Street (Sanborn } \\
\text { Map and Publishing Company, Ltd. 1904); see } \\
1403 \text { North Laredo Street] }\end{array}$ & Appler 1903:214 & $\begin{array}{l}\text { Gianotte, Peter, grocery, } \\
1401 \text { N Laredo, r same } \\
\text { Giorgia, Louis (Minnie), grocer, } \\
1401 \text { N Laredo }\end{array}$ \\
\hline $\begin{array}{l}1403 \text { North Laredo } \\
\text { Street [shown as } 1401, \\
1403,1405,1407 \\
\text { North Laredo Street } \\
\text { and also as } 101 \text { and } \\
103 \text { Rivas Street] }\end{array}$ & $\begin{array}{l}1 \text { story store building with metal roof, } \\
\text { attached warehouse with metal roof, } \\
\text { 2nd attached store building with metal } \\
\text { roof and associated } 10 \text { hp gasoline engine } \\
\text { at rear, attached } 1 \text { story dwelling with } \\
\text { metal and composition roof, and wood yard } \\
\text { (Sanbom Map and Publishing Company, Lrd. } \\
\text { 1911) }\end{array}$ & $\begin{array}{l}\text { Appler } 1903 \\
\text { Worley } 1927\end{array}$ & $\begin{array}{l}\text { [not listed] } \\
\text { [not listed] }\end{array}$ \\
\hline $\begin{array}{l}\text { 1403.5 North Laredo } \\
\text { Street [shown as } \\
\text { structure at rear of } \\
\text { property at corner of } \\
\text { North Laredo and } \\
\text { Garza Streets] }\end{array}$ & $\begin{array}{l}1 \text { story outbuilding with metal roof } \\
\text { (Sanborn Map and Publishing Company, Ltd. } \\
\text { 1911) }\end{array}$ & $\begin{array}{l}\text { Appler } 1903 \\
\text { Worley } 1927\end{array}$ & $\begin{array}{l}\text { [not listed] } \\
\text { [not listed] }\end{array}$ \\
\hline $\begin{array}{l}1405 \text { North Laredo } \\
\text { Street }\end{array}$ & $\begin{array}{l}\text { [see } 1403 \text { North Laredo Street (Sanbom Map } \\
\text { and Publishing Company, Ltd. 1911)] }\end{array}$ & $\begin{array}{l}\text { Appler } 1903 \\
\text { Worley } 1927\end{array}$ & $\begin{array}{l}\text { [not listed] } \\
\text { [not listed] }\end{array}$ \\
\hline $\begin{array}{l}1407 \text { North Laredo } \\
\text { Street }\end{array}$ & $\begin{array}{l}\text { [see } 1403 \text { North Laredo Street (Sanborn Map } \\
\text { and Publishing Company, Ltd. 1911) }\end{array}$ & $\begin{array}{l}\text { Appler } 1903 \\
\text { Worley } 1927\end{array}$ & $\begin{array}{l}\text { [not listed] } \\
\text { [not listed] }\end{array}$ \\
\hline $\begin{array}{l}\text { 1407.33 North Laredo } \\
\text { Street [shown at } \\
\text { rear of } 1403 \text { North } \\
\text { Laredo Street complex] }\end{array}$ & $\begin{array}{l}1 \text { story outbuilding with metal roof (Sanborn } \\
\text { Map and Publishing Company, Ltd. 1911) }\end{array}$ & $\begin{array}{l}\text { Appler } 1903 \\
\text { Worley } 1927\end{array}$ & $\begin{array}{l}\text { [not listed] } \\
\text { [not listed] }\end{array}$ \\
\hline $\begin{array}{l}1407.5 \text { North Laredo } \\
\text { Street [shown at } \\
\text { rear of } 1403 \text { North } \\
\text { Laredo Street complex] }\end{array}$ & $\begin{array}{l}1 \text { story outbuilding with metal roof (Sanborn } \\
\text { Map and Publishing Company, Ltd. 1911) }\end{array}$ & $\begin{array}{l}\text { Appler } 1903 \\
\text { Worley } 1927\end{array}$ & $\begin{array}{l}\text { [not listed] } \\
\text { [not listed] }\end{array}$ \\
\hline $\begin{array}{l}1415 \text { North Laredo } \\
\text { Street }\end{array}$ & $\begin{array}{l}1 \text { story dwelling with composition roof and } \\
1 \text { story outbuilding with composition roof } \\
\text { at rear (Sanbom Map and Publishing Company, } \\
\text { Ltd. 1904); } 1 \text { story dwelling [much larger } \\
\text { than the } 1904 \text { version] with metal roof and } \\
1 \text { story outbuilding with composition roof, } \\
\text { also second separate } 1 \text { story dwelling with } \\
\text { metal roof at rear labeled } 1415.5 \text { North } \\
\text { Laredo Street (Sanborm Map and Publishing } \\
\text { Company, Ltd. 1911) }\end{array}$ & $\begin{array}{l}\text { Appler 1903:157 } \\
\text { Worley } 1927\end{array}$ & $\begin{array}{l}\text { Craig, John (c), plasterer, } \\
\text { r } 1415 \text { N Laredo } \\
\text { [not listed] }\end{array}$ \\
\hline $\begin{array}{l}1419 \text { North Laredo } \\
\text { Street }\end{array}$ & $\begin{array}{l}1 \text { story dwelling with composition and metal } \\
\text { roof (Sanbom Map and Publishing Company, Ltd. } \\
\text { 1904); } 1 \text { story dwelling with composition and } \\
\text { metal roof, and } 2 \text { separate } 1 \text { story outbuildings } \\
\text { with composition roofs (Sanborn Map and } \\
\text { Publishing Company, Ltd. 1911) }\end{array}$ & Appler 1903:410 & $\begin{array}{l}\text { Schiedack, Otto C, harnessmaker } \\
\text { L Frank \& Co [Appler (1903:201) } \\
\text { lists: FRANKL \& CO (J D Straus, } \\
\text { D J Straus, props), wholesale } \\
\text { saddlery, 217-219 W Commerce, } \\
\text { r } 1419 \text { N Laredo] }\end{array}$ \\
\hline
\end{tabular}


TABLE 4. (continued)

\section{ADDRESS}

421 North Laredo

Street

1421.33 North Laredo

Street

1421.5 North Laredo

Street

1423 North Laredo Street [also shown as 100 West Poplar(?)

Street]

1501 North Laredo Street

1511 North Laredo Street

1515 North Laredo Street

1519 North Laredo Street

1523 and 1527 North Laredo Street [aiso shown as 101 Menchaca Street]

1601 North Laredo Street [also shown as 101 Menchaca Street]
1 story dwelling with composition and metal roof and 1 story outbuilding with metal roof (Sanborn Map and Publishing Company, Ltd. 1904); 1 story dwelling with metal roof and 4 outbuildings at rear, all 1 story, 2 with metal and 2 with composition roofs, 1 a dwelling labeled 1421.33 North Laredo Street, a second labeled 1421.5 North Laredo Street (Sanborn Map and Publishing Company, Ltd. 1911)

[see 1421 North Laredo Street (Sanbom Map and Publishing Company, Ltd. 1911)]

[see 1421 North Laredo Street (Sanborn Map and Publishing Company, Ltd. 1911)]

1 story dwelling with metal roof, 1 story outbuilding with composition roof (Sanborn Map and Publishing Company, Ltd. 1904); same information for 1911 (Sanborn Map and Publishing Company, Ltd. 1911)

unimproved (Sanbom Map and Publishing Company, Ltd. 1911)

1 story dwelling with composition and metal roof, 1 story outbuilding with metal roof (Sanbom Map and Publishing Company, Ltd. 1911)

1 story dwelling with composition and metal roof, 1 story outbuilding with metal roof (Sanborn Map and Publishing Company, Ltd. 1911)

1 story dwelling with composition and metal roof, 1 story outbuilding with metal roof (Sanbom Map and Publishing Company, Ltd. 1911)

1 story dwelling with composition and metal roof, 1 story outbuilding with metal roof (Sanborn Map and Publishing Company, Ltd. 1911)

unimproved (Sanborn Map and Publishing Company, Ltd. 1911)
Worley 1927:895

Appler 1903:315

Worley 1927:864

Appler 1903:372

Worley 1927:448

Appler 1903

Worley 1927

Appler 1903

Worley 1927

Appler 1903:163

Worley 1927

Appler 1903

Worley 1927

Appler 1903

Worley 1927:470

Appler 1903:398

Appler 1903

Worley 1927:411

Appler 1903

Worley 1927
Pigott, Wm M, blacksmith, 143 Main ave, r 1421 N Laredo

Duecker, Otto (Alma), h 1421 N Laredo

[not listed]

[not listed]

[not listed]

[not listed]

Darnall, J. P., painter, r $1423 \mathrm{~N}$ Laredo

[not listed]

[not listed]

[not listed]

[not listed]

Espitia, Maria, h 1511 N Laredo

Rouff, Samuel, clk L Wolfson [Wolfson, Leopold, dry goods, clothing, 413-421 W Commerce, r N Y.], r 1515 N Laredo

Pinken, Chas, r 1515 N Laredo Pinken, Jacob (Sarah), prop Diary, 1515 N Laredo

Martinez, Jose B., carp, r 1519 N Laredo

Ortiz, Nicolas (Isabel), trainmn, S A Public Service Co, h 1519 N Laređo

[not listed]

Cuellar, Benj (Mary), waiter, h $1523 \mathrm{~N}$ Laredo

[not listed either way]

[not listed] 
TABLE 4. (continued)

\begin{tabular}{|c|c|c|c|}
\hline ADDRESS & PROPERTY & REFERENCE & CITY DIRECTORY ENTRY \\
\hline $\begin{array}{l}1631 \text { North Laredo } \\
\text { Street }\end{array}$ & $\begin{array}{l}\text { unimproved (Sanbom Map and Publishing } \\
\text { Company, Ltd. 1911) }\end{array}$ & $\begin{array}{l}\text { Appler } 1903 \\
\text { Worley } 1927\end{array}$ & $\begin{array}{l}\text { [not listed either way] } \\
\text { [not listed] }\end{array}$ \\
\hline $\begin{array}{l}1700 \text { North Laredo } \\
\text { Street }\end{array}$ & $\begin{array}{l}\text { unimproved (Sanborm Map and Publishing } \\
\text { Company, Ltd. 1911) }\end{array}$ & $\begin{array}{l}\text { Appler } 1903 \\
\text { Worley } 1927\end{array}$ & $\begin{array}{l}\text { [not listed] } \\
\text { [not listed] }\end{array}$ \\
\hline $\begin{array}{l}1701 \text { North Laredo } \\
\text { Street [also shown } \\
\text { as } 101 \text { Lombrano } \\
\text { Street] }\end{array}$ & $\begin{array}{l}\text { map shows } 6 \text { separate outbuildings, all } \\
\text { apparently associated with the dwelling } \\
\text { and store at the corner of North Laredo } \\
\text { and Garza Streets (Sanbom Map and Publishing } \\
\text { Company, Ltd. 1911) [see entries for } 1721 \text { and } \\
\text { and } 1723 \text { North Laredo Street]; } 2 \text { of these are } \\
1 \text { story and are small, with metal roofs: } \\
\text { another is shown as a } 1 \text { story "auto ho" with } \\
\text { a metal roof; } 2 \text { other of the } 6 \text { structures are } \\
1 \text { story, iron clad, metal roofed, and labeled } \\
\text { "storage" and "shed," respectively; the last } \\
\text { of the } 6 \text { is a large, } 1 \text { story, iron clad, metal } \\
\text { roof building }\end{array}$ & $\begin{array}{l}\text { Appler } 1903 \\
\text { Worley 1927:1055 }\end{array}$ & $\begin{array}{l}\text { [not listed either way] } \\
\text { STOUT, J. C. LUMBER CO. } \\
\text { (Floyd D. Stout), Lumber, Sash, } \\
\text { Doors, Paints, Roofings, Builders } \\
\text { Materialand Builders Hardware, } \\
1701 \text { N Laredo, Tel Woodlawn } \\
3218 \\
\text { HARRISONGRAIN CO. (Sam } \\
\text { Harrison, O. P. Searle), 1624 W } \\
\text { Commerce, Tels Cr 7586, Tr } 476 \text {, } \\
\text { No } 21701 \text { NLaredo, Tel W } 1710\end{array}$ \\
\hline $\begin{array}{l}1702 \text { North Laredo } \\
\text { Street }\end{array}$ & $\begin{array}{l}1 \text { story dwelling, metal roof (Sanbom Map and } \\
\text { Publishing Company, Ldd. 1911) }\end{array}$ & $\begin{array}{l}\text { Appler } 1903 \\
\text { Worley 1927:793 }\end{array}$ & $\begin{array}{l}\text { [not listed] } \\
\text { Medrano, Guadalupe, h } 1702 \\
\text { N Laredo }\end{array}$ \\
\hline $\begin{array}{l}1704 \text { North Laredo } \\
\text { Street }\end{array}$ & $\begin{array}{l}1 \text { story dwelling, metal roof (Sanborn Map and } \\
\text { Publishing Company, Ltd. 1911) }\end{array}$ & $\begin{array}{l}\text { Appler } 1903 \\
\text { Worley 1927:397 }\end{array}$ & $\begin{array}{l}\text { [not listed] } \\
\text { Cordova, Antonio (Sotera), } \\
\text { truck dr, h } 1704 \text { N Laredo }\end{array}$ \\
\hline $\begin{array}{l}1706 \text { North Laredo } \\
\text { Street }\end{array}$ & $\begin{array}{l}1 \text { story dwelling, metal roof (Sanborn Map and } \\
\text { Publishing Company, Ltd. 1911) [also shows } \\
\text { small (storage shed?) } 1 \text { story, composition } \\
\text { roof building at rear (nearest creek) of } 1706 \\
\text { and } 1708 \text { North Laredo Street] }\end{array}$ & $\begin{array}{l}\text { Appler } 1903 \\
\text { Worley } 1927\end{array}$ & $\begin{array}{l}\text { [not listed] } \\
\text { vacant }\end{array}$ \\
\hline $\begin{array}{l}1708 \text { North Laredo } \\
\text { Street }\end{array}$ & $\begin{array}{l}1 \text { story storage building, metal roof (Sanborn } \\
\text { Map and Publishing Company, Ltd. 1911) }\end{array}$ & $\begin{array}{l}\text { Appler } 1903 \\
\text { Worley } 1927\end{array}$ & $\begin{array}{l}\text { [not listed] } \\
\text { vacant }\end{array}$ \\
\hline $\begin{array}{l}1723 \text { North Laredo } \\
\text { Street [corner Garza } \\
\text { and North Laredo } \\
\text { Streets, also shown } \\
\text { as } 102 \text { Fredericksburg } \\
\text { Road (or Garza }\end{array}$ & $\begin{array}{l}2 \text { story store building with metal roof, attached } \\
1 \text { story building with metal roof, attached } 1 \\
\text { story warehouse building with metal roof, } \\
\text { detached camp house with metal roof, } 4 \text { additional } \\
\text { outbuildings, either } 1 \text { or } 2 \text { story and either } \\
\text { composition or metal roofs, and camp yard (Sanbom }\end{array}$ & $\begin{array}{l}\text { Appler 1903:194 } \\
\text { Worley 1927:483 }\end{array}$ & $\begin{array}{l}\text { Fest, John, sr, groceries, etc, } \\
1723 \text { N Laredo, r } 102 \text { Garza } \\
\text { Fest, John (Mrs. Lena and John } \\
\text { Fest Jr., genl mdse } 1723 \text { N Laredo }\end{array}$ \\
\hline Street?)] & $\begin{array}{l}\text { Map and Publishing Company, Ltd. 1896); } 1904 \text { map } \\
\text { still shows same structures, but } 1896 \text { camp yard } \\
\text { has been considerably increased in size [almost } \\
\text { doubled], and largest } 1896 \text { outbuilding is labeled } \\
\text { as iron clad hay storage shed, "scales" have been } \\
\text { added to yard, a portion of } 1896 \text { store is veneered } \\
\text { dwelling, and there is an office to the far west } \\
\text { side in the new section of the camp yard (Sanborm } \\
\text { Map and Publishing Company, Ld. 1904); } 1911 \text { map } \\
\text { still shows same basic store, dwelling, camp yard, }\end{array}$ & & $\begin{array}{l}\text { Fest, John Jr. (Louisa; John } \\
\text { Fest) h. } 1608 \text { N Flores } \\
\text { Fest, John D. (Thelma) carp } \\
\text { h } 1915 \text { N Colorado } \\
\text { Fest, Lena (John Fest) } \\
\text { h } 927 \text { W Laurel }\end{array}$ \\
\hline
\end{tabular}


TABLE 4. (continued)

ADDRESS

1723 North Laredo Street (continued) and outbuildings as in 1904, but complex now includes the following additional addresses: 100, 104, and 106 [2nd store] Fredericksburg Road [or Garza? Street], 1701 North Laredo Street [see 1701 North Laredo Street], and 101 Lombrano Street [see entry at 1701 North Laredo Street]; also in 1911 there is a 1 story, iron clad, metal roofed "paint and wall paper" and "office" and a 1 story, iron clad, metal roofed "paint storage" outbuilding at 124 Garza Street, just east of the camp yard of the store complex at the corner of Garza and North Laredo Streets (Sanborn Map and Publishing Company, Ltd. 1911)

\section{WEST LAUREL STREET}

\subsection{West Laurel}

Street (Sanborn Map

and Publishing Company,

Ltd. 1911)

205.5 West Laurel
Street (Sanborn Map
and Publishing

Company, Ltd. 1911)

\section{LUNA STREET [today's West Cypress Street]}

115 Luna Street

118 Luna Street

(Sanborm Map and

Publishing Company,

Ltd. 1911)

134 Luna Street

(Sanborn Map and

Publishing Company,

Lud. 1911)

715 Luna Street

(Sanborn Map and

Publishing Company,

Ltd. 1911)

718 Luna Street (Sanborn Map and Publishing Company, Ltd. 1904)

\begin{tabular}{|c|c|}
\hline Appler 1903 & [not listed] \\
\hline Worley 1927 & [not listed] \\
\hline Appler 1903 & [not listed] \\
\hline Worley 1927 & [not listec \\
\hline
\end{tabular}

Appler 1903:290

Lacey, L. M. (wid W. M.), r 115 Luna

[structure closest to creek along Cameron Street at this location and time] (Sanborn

Map and Publishing Company, Ltd. 1904)

Appler 1903:200

Forsythe, James R, plumber, r 118 Luna

Worley 1927

[not listed]

Appler 1903

[not listed]

Worley 1927

[not listed]

Appler 1903

[not listed]

Worley 1927

[not listed]

Appler 1903

[not listed]

Worley 1927

[not listed]

Appler 1903

[not listed]

Worley 1927

[not listed] 
TABLE 4. (continued)

\begin{tabular}{|c|c|c|c|}
\hline ADDRESS & PROPERTY & REFERENCE & CITY DIRECTORY ENTRY \\
\hline \multicolumn{4}{|c|}{ MYRTLE STREET } \\
\hline 820 Myrtle Street & $\begin{array}{l}1 \text { story dwelling with composition and metal } \\
\text { roof, a combination } 1 \text { and } 2 \text { story outbuilding } \\
\text { with composition and metal roof, and a second } \\
\text { outbuilding with metal roof; adjacent unimproved } \\
\text { lot to the east adjoins creek (Sanborm Map and } \\
\text { Publishing Company, Ltd. 1911) }\end{array}$ & $\begin{array}{l}\text { Appler 1903:126 } \\
\text { Worley 1927:315 }\end{array}$ & $\begin{array}{l}\text { Buchanan, A. C. (wid D. A.), } \\
\text { r } 820 \text { W Myrtle } \\
\text { Brady, Roscoe K. (Adah), radio } \\
\text { eng, h } 820 \text { W Myrtle }\end{array}$ \\
\hline \multicolumn{4}{|l|}{ RIVAS STREET } \\
\hline 100.5 Rivas Street & $\begin{array}{l}1 \text { story outbuilding [?] with metal roof (Sanborn } \\
\text { Map and Publishing Company, Ltd. 1911) [shown } \\
\text { on the same tract with 1309-1323 North Laredo } \\
\text { Street] }\end{array}$ & $\begin{array}{l}\text { Appler } 1903 \\
\text { Worley } 1927\end{array}$ & $\begin{array}{l}\text { [not listed] } \\
\text { [not listed] }\end{array}$ \\
\hline
\end{tabular}




\section{TABLE 5. CITY DIRECTORY DATA ON MISCELLANEOUS RESIDENTS AND BUSINESSES IN OR NEAR THE SAN PEDRO CREEK-FIVE POINTS AREA}

\author{
RESIDENT AND/OR BUSINESS, OCCUPATION, TYPE OF \\ ESTABLISHMENT, AND ADDRESS
}

REFERENCE
Attorneys: Anderson, M. G., w s North Flores; Newcomb, James, w s North Flores Balies, Antonio, lab, res w s North Flores e of San Pedro Creek Barchers, Henry, gardener, res w s North Flores near San Pedro Springs Barrera, John, blacksmith L. J. Gembler, res west of San Pedro Creek Belzer, Reiman, wagon maker, L. J. Gembler, res west of San Pedro creek Bennett, Jane B., (wid) res w s North Flores

Bihl, Charles, clk, res n s Obraje bet Cameron and N. Flores Brewer, Miss Minnie, res e s North Flores bet Houston and Obraje Breweries: Esser, William, w s San Pedro Springs

Burns, Henry, carpenter, res w s North Flores

Caldwell, Alexander C., tinner, res cor North Flores and Obraje

Carpenters and Builders: McDowell, H. S., w s North Flores e of San Pedro creek

Cassiano, Jose, res n s Rivas bet Cameron and North Flores

Cassiano, Ygnacio, res n s Rivas bet Cameron and North Flores

Cayce, Isaac, cancer curer, res w $s$ North Flores

Chavez, Erasmo J., County Collector, office n w courthouse, res e s North Flores bet Houston and Obraje

Chavez, Ignatio, shoe shop ne cor North Flores and Obraje, res same

Cochran, Charles C., printer, res s w cor North Flores and Obraje

Danbury, Augustus, carpenter, res w s North Flores

Davis \& Giraud, (S.W. Davis and Leon J. Giraud) contractors and builders w $s$ obraje bet Acequia and North Flores

Davis, James, (col'd) barber, res n s Obraje bet North Flores and Cameron

Dietler, Franklin, grocer, e s North Flores east of San Pedro creek, res same

Dudley, Fannie, (col'd wid) res s s Obraje bet North Flores and Cameron

Fest, Henry, milk dairyman, res w s North Flores near San Pedro Springs

Fields, Benjamin, (col'd) res w s North Flores near San Pedro creek

Flores, Pablo, wks E. Lassner, res w s North Flores

French, James H., Mayor of San Antonio, res n s Obraje, bet North Flores and Cameron

Garcier, Francisco, res w s North Flores

Garcier, Josephine (wid) res w s North Flores on San Pedro creek

Garsia, John, lab, res w s North Flores near San Pedro creek

Garza, Rafael, lab, res w s North Flores nr San Pedro creek

Garzbach, Julius, carpenter, home S. Garzbach

Garzbach, Solomon, gardener, res w s North Flores

Gerzbach, Julius, cabinet maker R. Becker, res w s North Flores

Gilbert, Mrs. S. E., (wid) res North Flores

Hector, James P., civil engineer and surveyor, office w s St. Mary bet Houston and Travis, res w s North Flores

Hector, Oleanthus H., surveyor, home J. P. Hector

Kullmann, John D., musician, res w s north Flores

Kunkel, Louis, (Louis Kunkel \& Co. [Kunkel Louis \& Co., $s$ e cor Houston and North Flores; business portion of Moody and Morrison (1877:215): groceries and provisions]; res w s North Flores near San Pedro Springs

Leach, Robert H., res w s North Flores near San Pedro Springs

Loran, Anton, res e s North Flores, e of springs

Martin, John B., saddler, res w s North Flores

McDowell, H. S., carpenter, shop and res w s North Flores east of San Pedro creek

Neil, Rev. John W., pastor First Presbyterian Church, res w s North Flores

Nester, August, clk L. Wolfson, res n s North Flores

Newcomb, James, attorney, res w s North Flores
Moody and Morrison 1877:206

Moody and Morrison 1877:68

Moody and Morrison 1877:68

Moody and Morrison 1877:68

Moody and Morrison 1877:71

Moody and Morrison 1877:71

Moody and Morrison 1877:73

Moody and Morrison 1877:76

Moody and Morrison 1877:210

Moody and Morrison 1877:78

Moody and Morrison 1877:79

Moody and Morrison:1877:210

Moody and Morrison 1877:81

Moody and Morrison 1877:81

Moody and Morrison 1877:82

Moody and Morrison 1877:83

Moody and Morrison 1877:83

Moody and Morrison 1877:84

Moody and Morrison 1877:88

Moody and Morrison 1877:88

Moody and Morrison 1877:88

Moody and Morrison 1877:91

Moody and Morrison 1877:92

Moody and Morrison 1877:98

Moody and Morrison 1877:98

Moody and Morrison 1877:100

Moody and Morrison 1877:102

Moody and Morrison 1877:104

Moody and Morrison 1877:104

Moody and Morrison 1877:105

Moody and Morrison 1877:105

Moody and Morrison 1877:105

Moody and Morrison 1877:105

Moody and Morrison 1877:106

Moody and Morrison 1877:106

Moody and Morrison 1877:115

Moody and Morrison 1877:130

Moody and Morrison 1877:130

Moody and Morrison 1877:130 Moody and Morrison 1877:133

Moody and Morrison 1877:137

Moody and Morrison 1877:140

Moody and Morrison 1877:142

Moody and Morrison 1877:151

Moody and Morrison 1877:152

Moody and Morrison 1877:152 
TABLE 5. (continued)

\section{RESIDENT AND/OR BUSINESS OCCUPATION, TYPE OF}

ESTABLISHMENT, AND ADDRESS

REFERENCE

Petitpain, Oscar, auctioneer, res s s Rivas bet Cameron and North Flores

Moody and Morrison 1877:152

Riedner, Albert, tailor Pancoast and Son [Pancoast \& Son, 88

and 90 Commerce (Moody and Morrison 1877:219), merchant taylors] res near San Pedro Springs

Rowland, Joseph G., gardener, res e s North Flores

Saloons: San Pedro Springs, Durler Bros., managers

Salter, James, carpenter, res n s North Flores

Saueleben [probably actually Santleben], August, freighter, res e s North Flores near San Pedro Springs

Scalley, Joshua W., res e s North Flores

Schelcher, Joseph, farmer, w s San Pedro Springs

Seigler, F., gardener, res w s North Flores

Sneider, Mrs. Catherine, (wid) res w s North Flores

Strasser, Anton, hay dealer, res e s North Flores near San Pedro Springs

Tarleton, Leo, (S. Cayce \& Co. [Cayce S. \& Co., e s Soledad bet Commerce and Houston (Moody and Morrison 1877:206), attorneys]) attorney, res e s North Flores

Vollker, Mrs. E., (wid) res North Flores near San Pedro creek

Wagon Yards: Adams, Rice, e s North Flores

Welsh [actually Walsh], Patrick, contractor, res w s North Flores

Williams, Patsie, (col'd) res w s North Flores

Attorneys at Law: Berry, Walker W., 1177 N Flores

Amusements: San Pedro Springs Park, N end San Pedro ave, Fred Kerbel prop

Bailey, Sarah Mrs., (wid Albert), h 411 Lombrano

Berry, Walker W., attorney at law, h 1177 N Flores

Black, Herman, waiter San Pedro Park, h 814 N Flores

Black, Lizzie Mrs., h 814 N Flores

Blackman, David W., h 630 N Flores

Blacksmiths and Wheelwrights: Spangler, cor Laredo and N Flores

Blumme, Max, driver street sprinkler, h 688 N Flores

Bockmann, Ferdinand, slsmn Elmendorf \& Co. [Elmendorf \& Co., $\mathrm{N}$ side Military plaza, $\mathrm{T} 235$. See advertisement p. 22 (Johnson and Chapman 1891:421), agricultural implements], h $694 \mathrm{~N}$ Flores

Bogel, Cyrus (c), lab, b 71 Utica

Bogel, James (c), lab, b 71 Utica

Bogel, Marguerite, Mrs., laundress, h 71 Utica

Bogel, Richard (c), lab, b 71 Utica

Brouthers, Nelson G., b 679 N Flores

Burke, John J., h 1184 N Flores

Burnett, John F., stockman, h 636 N. Flores

Bussey, Albert, porter San Pedro Springs Saloon, h Laurel Heights

Caldwell, Fanny L., (wid A. C.), h 648 N Flores

Caldwell, Frank J., reporter Daily Times, h 648 N Flores

Campbell, Thomas B., yardman Gauss \& Johns [Gauss \& Johns, 336 S Flores, T 329 (Johnson and Chapman 1891:446), lumber, lath and shingles], $b$ N Flores

Chavez, Ignacio, shoemaker, h Beitel nr San pedro creek

Church, F. W., bkpr D. Sullivan \& Co. [Sullivan, D., \& Co., 251 W Commerce, T 186 (Johnson and Chapman 1891:423), banks and bankers], h 658 N Flores

Concert Gardens: San Pedro Springs Park, N end San Pedro ave, F. Kerpel, prop

Cordona, Ignacio, tinner Joseph Dean [Dean, Joseph, 9 Military plaza (Johnson and Chapman 1891:462), stoves and tinware], $h-N$ Flores

Moody and Morrison 1877:164

Moody and Morrison 1877:167

Moody and Morrison 1877:224

Moody and Morrison 1877:169

Moody and Morrison 1877:171

Moody and Morrison 1877:171

Moody and Morrison 1877:171

Moody and Morrison 1877:175

Moody and Morrison 1877:179

Moody and Morrison 1877:182

Moody and Morrison 1877:185

Moody and Morrison 1877:192

Moody and Morrison 1877:224

Moody and Morrison 1877:196

Moody and Morrison 1877:199

Johnson and Chapman 1891:421

Johnson and Chapman 1891:422 Johnson and Chapman 1891:89 Johnson and Chapman 1891:101 Johnson and Chapman 1891:103 Johnson and Chapman 1891:103 Johnson and Chapman 1891:103 Johnson and Chapman 1891:425 Johnson and Chapman 1891:105

Johnson and Chapman 1891:105 Johnson and Chapman 1891:105 Johnson and Chapman 1891:105 Johnson and Chapman 1891:105 Johnson and Chapman 1891:105 Johnson and Chapman 1891:113 Johnson and Chapman 1891:117 Johnson and Chapman 1891:118 Johnson and Chapman 1891:119 Johnson and Chapman 1891:120 Johnson and Chapman 1891:120

Johnson and Chapman 1891:122 Johnson and Chapman 1891:128

Johnson and Chapman 1891:130

Johnson and Chapman 1891:431

Johnson and Chapman 1891:137 

materials], h $744 \mathrm{~N}$ Flores

Dry Goods: Fest, John, cor N Flores and Fredericksburg road

Dry Goods: Wohlfarth, Jacob, 900 N Flores [Note: The 1896 Sanborn map shows this establishment at $1602 \mathrm{~N}$ Flores; thus, a renumbering of Flores St. must have occurred between 1890 and 1896.]

Dotson, Louis (c), lab, h-Fredericksburg road

Dotson, Robert (c), stonemason, h-Fredericksburg road

Dotson, William (c), teamster, h-Fredericksburg road

Emery, Samuel, stockman, h 655 N Flores

Fournier, Anton F., receiving clk I. \& G. N. frt. office, h 888 N Flores

Fry, Daniel W., painter, h $742 \mathrm{~N}$ Flores

Gamble, Henry, teamster Gahwiler \& Simmang [Gahwiler \& Simmang, 612 N Flores, T 377 (Johnson and Chapman 1891:446) lumber, lath and shingles], $\mathrm{r} 612 \mathrm{~N}$ Flores

Geddes, David J., h 697 N Flores

Geddes, Ella, Miss, h 697 N Flores

Geddes, James, miller, h 697 N Flores

Geddes, Lizzie, Miss, h 697 N Flores

Geddes, Maggie, Miss, h 697 N Flores

Gerard, Fernando, brtdr N. A. Nohse [Nohse, Henry A., 808 W Commerce (Johnson and Chapman 1891:458), saloons], h N Flores and Fredericksburg road

Gomez, Angel, ranchman, h 1025 N Laredo

Goodloe, Albert, compositor G.F. Sigmund [Sigmund, Gustav F., 268 Market (Johnson and Chapman 1891:452), printers: book and job], $h 76$ Utica (later Poplar Street)

Goodloe, Charles, carp, h 77 Utica (later Poplar Street)

Goodloe, Guy, photographer A. C. Paris [p. 305: Paris, Arthur C., photographer (Paris \& Rothwell), h 16 National; PARIS \& ROTHWELL (A. C. Paris and I. N. Rothwell), photographers, 11 and $13 \mathrm{~W}$ Commerce; Paris \& Rothwell, 11 and $13 \mathrm{~W}$ Commerce (Johnson and Chapman 1891:451), photographers], h 76 Utica

Green, Harry, lab San Pedro Park

Grocers: Fest, John, cor N Flores and Fredericksburg road

Harris, Mary, Mrs., washwoman, h 706 N Flores

Harris, Sam S., paper hanger and decorator B. C. Riely \& Co. [p. 326: RIELY, B. C. \& Co. (Benjamin C. Riely and Wm. L. Herff), paints, oils and wall paper $42 \mathrm{~W}$ Commerce, T 447 (see advertisement top marginal lines); Riely, Benjamin C., paints, oils and wall paper (B. C. Riely \& Co.), h 307 Virginia ave, West End; Riely, B. C. $\&$ Co., $42 \mathrm{~W}$ Commerce, $\mathrm{T} 477$. See adv marginal lines (Johnson and Chapman 1891:450), paints, oils, and painters' supplies], h-N Flores

Haywood, Samuel (c), teamster, h 765 N Flores

Helman, B. J., bkpr R. W. Lay \& Co. [(Johnson and Chapman 1891:251) Lay, Robert W., genl insurance (R. W. Lay \& Co.), b Acequia between Salinas and Rodriguez; Lay, R. W. \& Co. (Robt. W. Lay and - Co.), genl insurance, 425 E Houston, T 397; Lay, R.W. \& Co., 425 E Houston, T 397 (Johnson and Chapman 1891:443), insurance-fire companies and agents], h $648 \mathrm{~N}$ Flores

Henschkel, William L., cement, h cor Jackson and Utica (later Poplar Street)

Hensley, Alexander D., paints, oils and wall paper (A. T. Hensley \& Sons), $\mathrm{T} 179$, h $796 \mathrm{~N}$ Flores

Hensley, Alexander T, paints, oils and wall paper (A. T. Hensley \& Sons), T 179, h 796 N Flores

Johnson and Chapman 1891:139 Johnson and Chapman 1891:434

Johnson and Chapman 1891:435 Johnson and Chapman 1891:154 Johnson and Chapman 1891:154 Johnson and Chapman 1891:154 Johnson and Chapman 1891:163 Johnson and Chapman 1891:174 Johnson and Chapman 1891:178

Johnson and Chapman 1891:180 Johnson and Chapman 1891:180 Johnson and Chapman 1891:180 Johnson and Chapman 1891:180 Johnson and Chapman 1891:180 Johnson and Chapman 1891:180

Jonhson and Chapman 1891:184 Johnson and Chapman 1891:189

Johnson and Chapman 1891:190 Johnson and Chapman 1891:190

Johnson and Chapman 1891:190 Johnson and Chapman 1891:193 Johnson and Chapman 1891:439 Johnson and Chapman 1891:204

Johnson and Chapman 1891:204 Johnson and Chapman 1891:208

Johnson and Chapman 1891:209 Johnson and Chapman 1891:210

Johnson and Chapman 1891:210

Johnson and Chapman 1891:210 
TABLE 5. (continued)

\section{RESIDENT AND/OR BUSINESS OCCUPATION, TYPE OF ESTABLISHMENT, AND ADDRESS}

\section{REFERENCE}

Johnson and Chapman 1891:210

Johnson and Chapman 1891:211

Johnson and Chapman 1891:211

Johnson and Chapman 1891:211

Johnson and Chapman 1891:210

Johnson and Chapman 1891:213

Johnson and Chapman 1891:215

Johnson and Chapman 1891:216

Johnson and Chapman 1891:217

Johnson and Chapman 1891:223

Johnson and Chapman 1891:230 Johnson and Chapman 1891:232

Johnson and Chapman 1891:238

Johnson and Chapman 1891:238

Johnson and Chapman 1891:239

Johnson and Chapman 1891:242

Johnson and Chapman 1891:243

Johnson and Chapman 1891:260

Johnson and Chapman 1891:261

Johnson and Chapman 1891:266 Johnson and Chapman 1891:281 Johnson and Chapman 1891:282 Johnson and Chapman 1891:295

Johnson and Chapman 1891:300

Johnson and Chapman 1891:301 Johnson and Chapman 1891:307

Johnson and Chapman 1891:315 Johnson and Chapman 1891:319 Johnson and Chapman 1891:320 Johnson and Chapman 1891:321 
TABLE 5. (continued)

Reichel, William, apprentice Snodgrass \& Cade [(Johnson and Chapman 1891:364)

SNODGRASS \& CADE (T. E. Snodgrass \& W. H.

Cade), props Excelsior Planing Mill, 22 to 26 Ave C, T

274; Snodgrass \& Cade, 22 to 26 Ave C, T 274

(Johnson and Chapman 1891:452), planing mills], h $741 \mathrm{~N}$ Flores Johnson and Chapman 1891:322

Reynolds, John H., trav slsmn and broker, h 656 N Flores

Robb, Edwina D., Miss, principal public school No. 7, b 1180 N Flores

Robb, Harvey J., carp, b $1180 \mathrm{~N}$ Flores

Robb, John G., stockman, b 1180 N Flores

Robb, Mary J., Mrs. (wid Joseph), h 1180 N Flores

Saloons: Fest, John, cor N Flores and Fredericksburg road; John

Fest Saloon, cor Blanco and Fredericksburg road, Gotthard

\& Leonard props; Kerble, F., prop San Pedro Park

Saloon (see advertisement); Wohlfarth, Jacob, 900 N Flores

Salter, Emma, Miss, h 659 N Flores

San Pedro Springs Park, end San Pedro ave, Fred Kerble prop

Santleben August, stockman and transfer line (Froboese \&

Santleben), T 359, h 688 N Flores

Santleben, Frederick, shipping clk Froboese and Santleben, h 688 N Flores

Santleben, Sophie, Miss, h 688 N Flores

Santleben, William, brtdr Arbeiter Verein Hall [Arbeiter Verein

Hall, 284 E Commerce, L. S. Taft prop. (Johnson and Chapman 1891:456), saloons]

Schaeper, Ernst, stonecutter Frank Teich [(Johnson and Chapman 1891:379) Teich,

Frank, Granite Marble and Iron Work, office - E

Houston, T 513, h 608 Goliad; Teich, Frank, nr Aransas

Pass depot. See advertisement (Johnson and Chapman 1891:446), marble yards; see related entry (Johnson and Chapman 1891:406) Wild, Augustus J.]

h Fredericksburg Road nr N Flores

Schairer, Josephine, Mrs., h Laurel between San Pedro Creek and N Flores

Schmitt, Anton, gardener San Pedro Park, b same

Seeley, W. B., Mrs. vice prest protestant Home for Destitute Children, h $1185 \mathrm{~N}$ Flores

SEELEY, WILLIAM B., principal San Antonio Academy, h 1185

N Flores. See advertisement

Shiner, Bee, stockman, h 1183 N Flores

Shiner, Marshall K, stockman, h 619 N Flores

Shoemaker, Charles, carp, h--N Flores

Sholtz, Annie, Miss, emp D.W. Heard [(Johnson and Chapman 1891:208) Heard, David

W., real estate, 4 Devine bldg, h 616 N Flores; Heard,

David W., 616 N Flores, business directory, real estate],

h 616 N Flores

Shooting Galleries: San Pedro Park, end San Pedro ave

Siebenmann, Edward, asst janitor second ward school, h 735 N Flores

Siebenmann, Hermann, janitor second ward school, h $735 \mathrm{~N}$ Flores

Siebenmann, Lina, Miss, h $735 \mathrm{~N}$ Flores

Siebanmann, William, collector Froboese \& Santleben, h 735 N Flores

Simmang, Richard, grocery and saloon, cor Marshall and N Flores

Smith, David, lab, h 411 Lombrano [See also first entry in this series: Bailey, Mrs. Sarah]

Smith, Elijah B., team owner, h 411 Lombrano [See entry immediately preceding]

Smith, Minnie, Miss, h 411 Lombrano [See previous two entries]

Smith, John H., clk F. T. Walsh \& Bro., h Lambrano nr N Flores

Spangler, Henry, blacksmith, h 741 n Flores

Steinbach, Frederick, brtdr San Pedro Springs saloon, h 222 Martinez

Storbeck, Caroline, Mrs., rooms to rent, h 228 Blum

Johnson and Chapman 1891:324

Johnson and Chapman 1891:328

Johnson and Chapman 1891:328

Johnson and Chapman 1891:328

Johnson and Chapman 1891:329

Johnson and Chapman 1891:457

Johnson and Chapman 1891:338

Johnson and Chapman 1891:341

Johnson and Chapman 1891:342

Johnson and Chapman 1891:342

Johnson and Chapman 1891:342

Johnson and Chapman 1891:342

Johnson and Chapman 1891:344

Johnson and Chapman 1891:344

Johnson and Chapman 1891:347

Johnson and Chapman 1891:353

Johnson and Chapman 1891:353

Johnson and Chapman 1891:357

Johnson and Chapman 1891:357

Johnson and Chapman 1891:357

Johnson and Chapman 1891:357

Johnson and Chapman 1891:460

Johnson and Chapman 1891:357

Johnson and Chapman 1891:357

Johnson and Chapman 1891:357

Johnson and Chapman 1891:358

Johnson and Chapman 1891:358

Johnson and Chapman 1891:361

Johnson and Chapman 1891:361 Johnson and Chapman 1891:361

Johnson and Chapman 1891:362

Johnson and Chapman 1891:366

Johnson and Chapman 1891:370

Johnson and Chapman 1891:373 
TABLE 5. (continued)

\section{RESIDENT AND/OR BUSINESS OCCUPATION, TYPE OF} ESTABLISHMENT, AND ADDRESS

REFERENCE

Storbeck, Robert, clk, h Rivas between N Comal and N Laredo [See related entry under Julia Herman and Robert Storbeck]

Storbeck, Robert, music teacher, h 228 Blum

Strosser, Robert, blacksmith apprentice Henry Spangler, b 741 N Flores

Tchirhart, Emil P., barber, h 645 N Flores

Thomas, James E., trav slsmn New Home Sewing Machine Co. [not listed in either main or business directories, perhaps due to the fact that it had no office here then], h $800 \mathrm{~N}$ Flores

Toepperwein, William, lab, h $890 \mathrm{~N}$ Flores

Transfer, Baggage and Freight: Zoller, Charles \& Co., 728 N Flores

Tschirhart, Emil P., barber, 220 Dolorosa, h 645 N Flores

Wagner, Henry C., clk auditor's office S. A. \& A. P. Ry, h 70 Utica

Warren, Green W., broom mkr, h cor San Marcos and Laredo

Weller, Samuel B., crockery and glassware (Newton \& Weller), $T$ 304, h 615 N Flores

Wheeler, Bruce, emp San Antonio Street Ry Co, h 1189 N Flores

Wild, Augustus J., granite cutter Frank Teich [See listing Schaeper, Ernst (Johnson and Chapman 1891:344)], h Fredericksburg road nr N Flores

Williams, Albert, brtdr, h 814 N Flores

Williams, Paulina, h 814 N Flores

Wright, Ella, Mrs. (wid James), h 411 Lombrano [See related entries Bailey, Mrs. Sarah and Smith, David, Elijah, and Minnie]

Wripps, Mike, carp, h cor San Marcos and Laredo

Johnson and Chapman 1891:373

Johnson and Chapman 1891:373

Johnson and Chapman 1891:373

Johnson and Chapman 1891:378

Johnson and Chapman 1891:380

Johnson and Chapman 1891:383

Johnson and Chapman 1891:463

Johnson and Chapman 1891:385

Johnson and Chapman 1891:394

Johnson and Chapman 1891:398

Johnson and Chapman 1891:402

Johnson and Chapman 1891:404

Johnson and Chapman 1891:406

Johnson and Chapman 1891:407

Johnson and Chapman 1891:407

Johnson and Chapman 1891:413

Johnson and Chapman 1891:414 


\section{REFERENCES CITED}

Appler, J. A.

1895 General Directory of the City of San Antonio, 1895-1896. San Antonio.

1901 General Directory of the City of San Antonio, 1901-1902. San Antonio.

1903 General Directory of the City of San Antonio, 1903-1904. San Antonio.

Friesleben, G.

1855 Plat of Lands on San Pedro Springs Belonging to $S$. S. Smith. On file in the records plant of Stewart Title Company's Mossrock Drive office, San Antonio, Texas.

1885 Plat of Lots on North Flores and Luna Streets Belonging to Henry Fest, March 1885. On file in the records plant of Stewart Title Company's Mossrock Drive office, San Antonio, Texas.

Johnson and Chapman

1891 General Directory of the City of San Antonio, 1891. San Antonio.

Locke, W.

1889 Plat on file in the records plant of Stewart Title Company's Mossrock Drive office, San Antonio, Texas.

Moody and Morrison

1877 Directory of the City of San Antonio, 1877-1878. Galveston.

Morrison and Fourmy

1881 General Directory of the City of San Antonio, 1881-1882. Austin.

1885 General Directory of the City of San Antonio, 1885-1886. Galveston.

Sanborn Map and Publishing Company, Ltd. 1896 Map of San Antonio, Texas. New York.

1904 Map of San Antonio, Texas. New York.

1911 Map of San Antonio, Texas. New York.
San Antonio River Authority (SARA)

n.d. Plat of area between Myrtle and Laurel Streets.

Stewart Title Company

1885 Plat of area between south border of Henry Borchers tract and north border of George White tract. On file at the records plant of Stewart Title Company's Mossrock Drive office, San Antonio, Texas.

1887? Plat of area between Marshall and Luna (later West Cypress Street) Streets. On file at the records plant of Stewart Title Company's Mossrock Drive office, San Antonio, Texas.

1892 Unnamed plat map on file in the records plant of Stewart Title Company's Mossrock Drive office, San Antonio, Texas.

1928 Plat of extension of Evergreen Street. May 28. On file at the records plant of Stewart Title Company's Mossrock Drive office, San Antonio, Texas.

n.d.a Plat of subdivision of original Borchers tract (east side of creek only). On file at the records plant of Stewart Title Company's Mossrock Drive office, San Antonio, Texas.

n.d.b Plat of subdivision of Diether and Wright tract between North Flores Street and main ditch. On file at the records plant of Stewart Title Company's Mossrock Drive office, San Antonio, Texas.

n.d.c Plat of Block 212, Lot 5. On file at the records plant of Stewart Title Company's Mossrock Drive office, San Antonio, Texas.

Worley, J. F.

1927 San Antonio City Directory, 1927-1928. San Antonio. 


\section{APPENDIX II}

\section{ARCHIVAL RESEARCH ON NEW CITY BLOCK 1917, LOTS 6 AND 12, AND A BRIEF HISTORY OF NORTH FLORES AND MYRTLE STREETS}

\section{Waynne Cox}

\section{INTRODUCTION}

In May 1987, the CAR-UTSA contracted with the SARA to conduct archival research for the buildings on New City Block (NCB) 1917, Lots 6 and 12, in northwestern San Antonio, Bexar County, Texas. Texas Antiquities Committee Permit No. 818 was issued for the project.

\section{HISTORY OF LOTS 6 AND 12, NCB 1917}

The study area is located at the Five Points intersection of Fredericksburg Road, North Flores, Laredo, Laurel, and Camaron Streets. This intersection has long been a landmark for travelers to and from the city. The pasito de los Apaches or "little pass of the Apaches" crossing of San Pedro Creek was the traditional exodus point from the villa to the lands of the hill country and the access to the popular San Pedro Springs.

Lots 6 and 12 were within the original 26,568 acres granted by King Philip of Spain in 1729 (Crook 1967:7). In 1731, Francisco Arocha, as one of the Canary Islanders, was granted a suerte (luck or draw) of land in the villa of San Fernando de Bexar (Chabot 1937:146). Arocha, a native of Palma, was 27 years old upon his arrival in the small frontier settlement. He was described as “... tall, long face, grey eyes, dark complexion, meeting eyebrows, thick beard, thin nose, black hair" (Austin 1905:335). He married Juana Curbelo, daughter of Juan, in Mexico City on their journey to Texas. A native of Lancerota, only 14 years old at the time, she was described as "full faced, dark complexion, grey eyes, black hair and eyebrows, flat nose" (Austin ibid.; Buck 1980:61). In 1743, Arocha petitioned for another plot of land on the other side of San Pedro Creek ( $L G S 1743$ No. 2). It appears that shortly after he acquired the land he constructed a short (410 varas or 1138.5 feet) acequia or irrigation ditch through the middle of the property. The only evidence to support its existence is documented in the city surveyor's plat book (City Survey Book 1850 Vol. I:138).

In 1851, the City of San Antonio, through a redefinition of the original Royal Grant, obtained the property as Public Lands (Texas Supreme Court Records 1883). In 1852, Samuel S. Smith purchased Lot 2, Range 4, District 3, containing six and 15/100 acres from the city for $\$ 195$ ( $D R$ Vol. L1:93). Smith, called el barbon or "Big Beard," had served as mayor in 1847 and later served many years as county and district clerk (Chabot 1937:275; Buck 1980:285). He sold the lot, along with the adjacent 8-1/2 acres, to William Lange in 1865 ( $D R$ Vol. T1:326). Frederick William Lange was a blacksmith and wheelwright (Moody and Morrison 1877). Lange sold the two lots to Martin Muench, in 1872, for $\$ 5500$ ( $D R$ Vol. W2:295). Muench, a cotton, wool, and hide broker and frequent city councilman, subdivided the tract into town lots and sold Lots 1, 2, and 3 to Peter Jonas, a saloon keeper and later county judge, for $\$ 195$ ( $D R$ Vol. 7:16). Jonas redivided the property and sold Lots 6 and 12 , now in their present configuration, to Jacob Wohlfarth in April 1884 (DR Vol. 37:20). Wohlfarth built the structure on the corner of Laurel, Fredericksburg, and Flores Streets (1602 North Flores Street) shortly after that date (Figs. 4 and 5).

Wohlfarth, formerly a cook and pantryman for the Menger Hotel, established a general merchandise, grocery store, and camp yard on the property that would function for over 25 years (Morrison and Fourmy 1885, 1887, 1889; Appler 1892, 1895, 1897, 1899, 1901, 1903, 1905, 1907, 1908, 1909; Texas Publishing Company 1910). He also resided in the rear of the structure until approximately 1925 when he moved his residence to the Laurel Heights addition (San Antonio Conservation Society n.d.). Between 1912 and 1922 , the business was leased to A. H. Nathan for the Five Points Drug Store. In approximately 1925, the entrance was changed to face the south, and the address became 823 West Laurel Street. The buildings to the rear of the structure (815-821 West Laurel Street) were apparently constructed at that time (Fig. 6). They consisted of the Five Points Lunchroom (815 West Laurel Street), Piggly Wiggly No. 18 (817 West Laurel Street), a bakery shop (819 West Laurel Street), three apartments (819-1/2 West Laurel Street), and the Five Points Fruit Store and Chicago Brothers (821 West Laurel Street). 


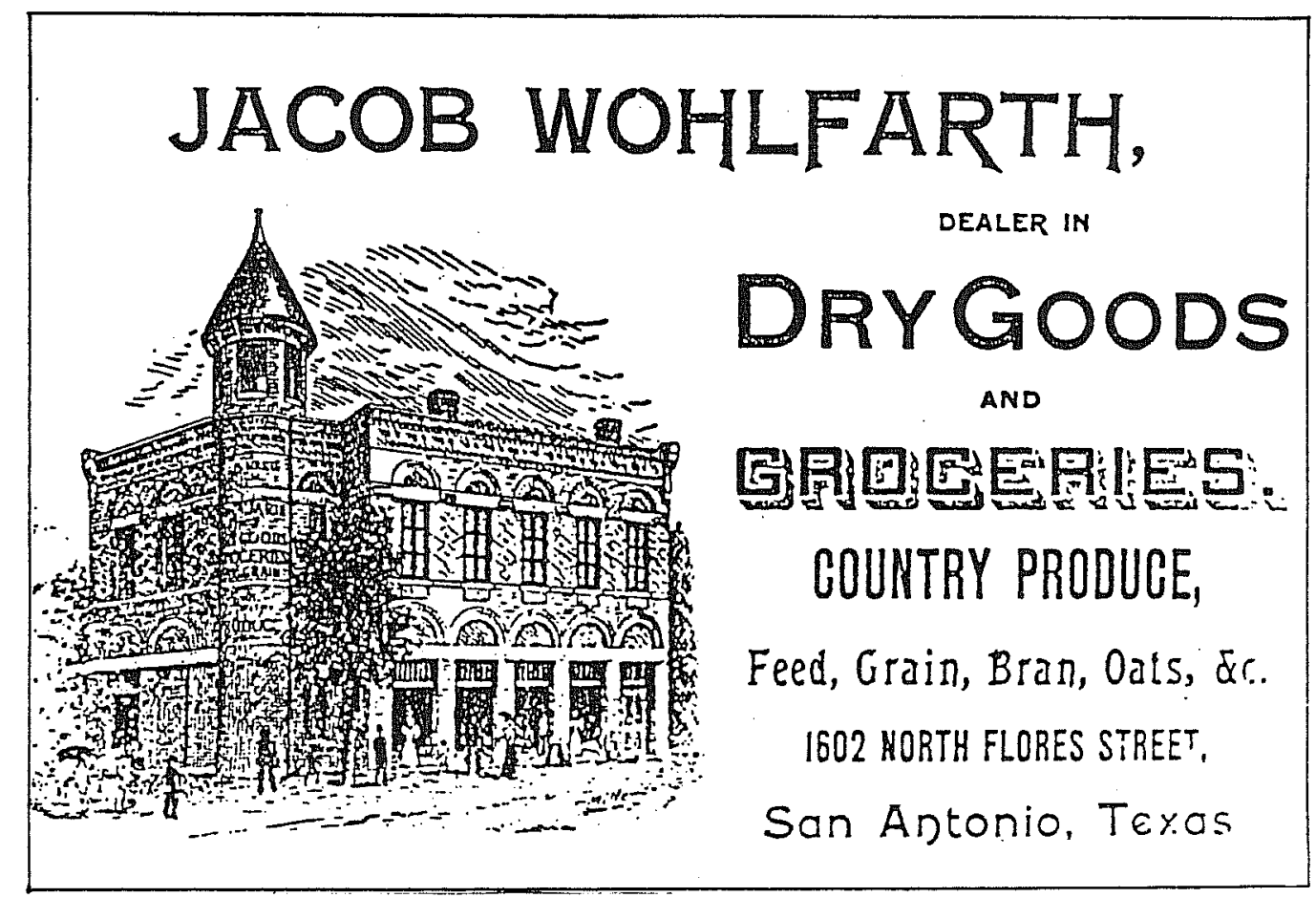

Figure 4. The Jacob Wohlfarth Structure, ca. 1885. Located at 823 West Laurel Street (previously 1602 North Flores Street). Copy of advertisement provided by Mrs. Walter Kutschereuter.

The building at 823 West Laurel Street was operating as Martin's Pharmacy No. 1, with J. H. Martin proprietor (Appler 1924; Worley 1926, 1927). By 1934, the buildings at 815 and 817 West Laurel Street had become the Schussler Cafe, Rudolph H. Schussler proprietor (Worley 1934-1935). Martin's drug store closed in 1938, and the building was vacant until 1945 (Worley 1938-1939, 1940-1941, 1942-1943).

Jacob Wohlfarth died in 1945, and the heirs disposed of the property (Wills and Probate Records No. 53763). The structure at 823 West Laurel Street was purchased by Peter Ramirez and became Pete's Liquor Store No. 3. In 1955, the structures at 815-817 West Laurel Street became the Five Points Cafe and Lounge under the management of Sam Plainos and Theo Chakiri. Subsequently, the Five Points Butcher Shop was established there and operated by Merton C. Norman. The structure at 823 West Laurel Street was then named Pete's Five Points Liquor Store (Worley 1955-1956). In 1958, the liquor store was renamed Repete at Pete's, and the portion of the building at 821 West Laurel Street was occupied by the Mechanic's Tool and Equipment Company (Polk 1958). In 1960, the structure at 821 West Laurel Street was vacant, while the other occupants remained the same until 1970, when the building at 819 West Laurel Street became the Five Points Watch Repair shop of Bill
E. McCarty (Polk 1970). Around 1970, the building at 815-817 West Laurel Street was converted to the Spanish Armada Lounge. This was the final occupation of the building.

\section{CONCLUSIONS AND RECOMMENDATIONS}

Of the structures on either Lot 6 or Lot 12, only the 1885 building at 823 West Laurel Street has historical significance, and it is not possible to ascertain from the archival materials how later alterations have affected the structure. On-site observation indicates that the north wall and the wooden structure to the rear are portions of the original building. Should the structure be demolished or moved, a qualified archaeologist should be present to monitor and record any historic or prehistoric evidence that might be revealed. 


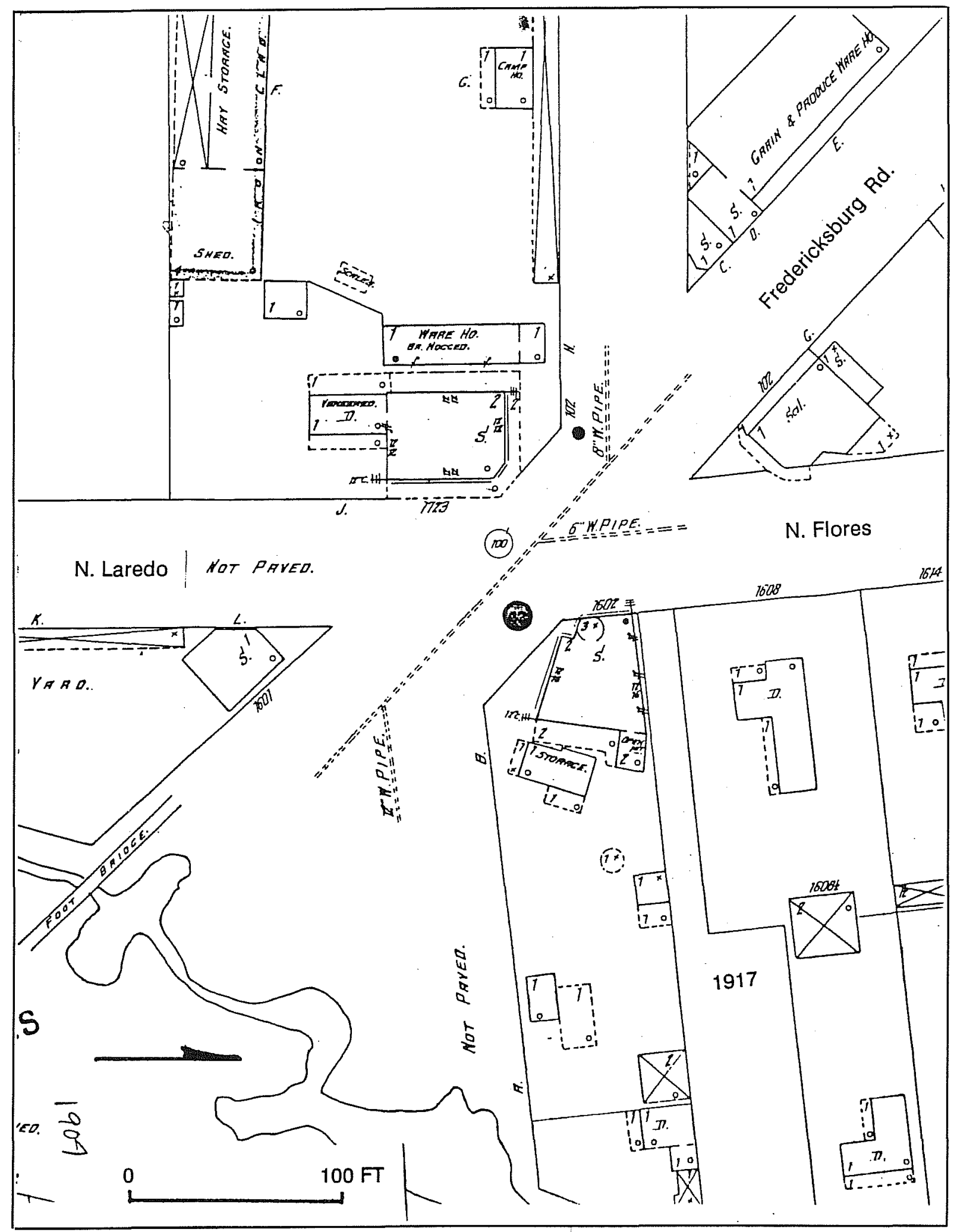

Figure 5. NCB 1917 in 1904. Sanborn Map and Publishing Company, Ltd. (1904). 


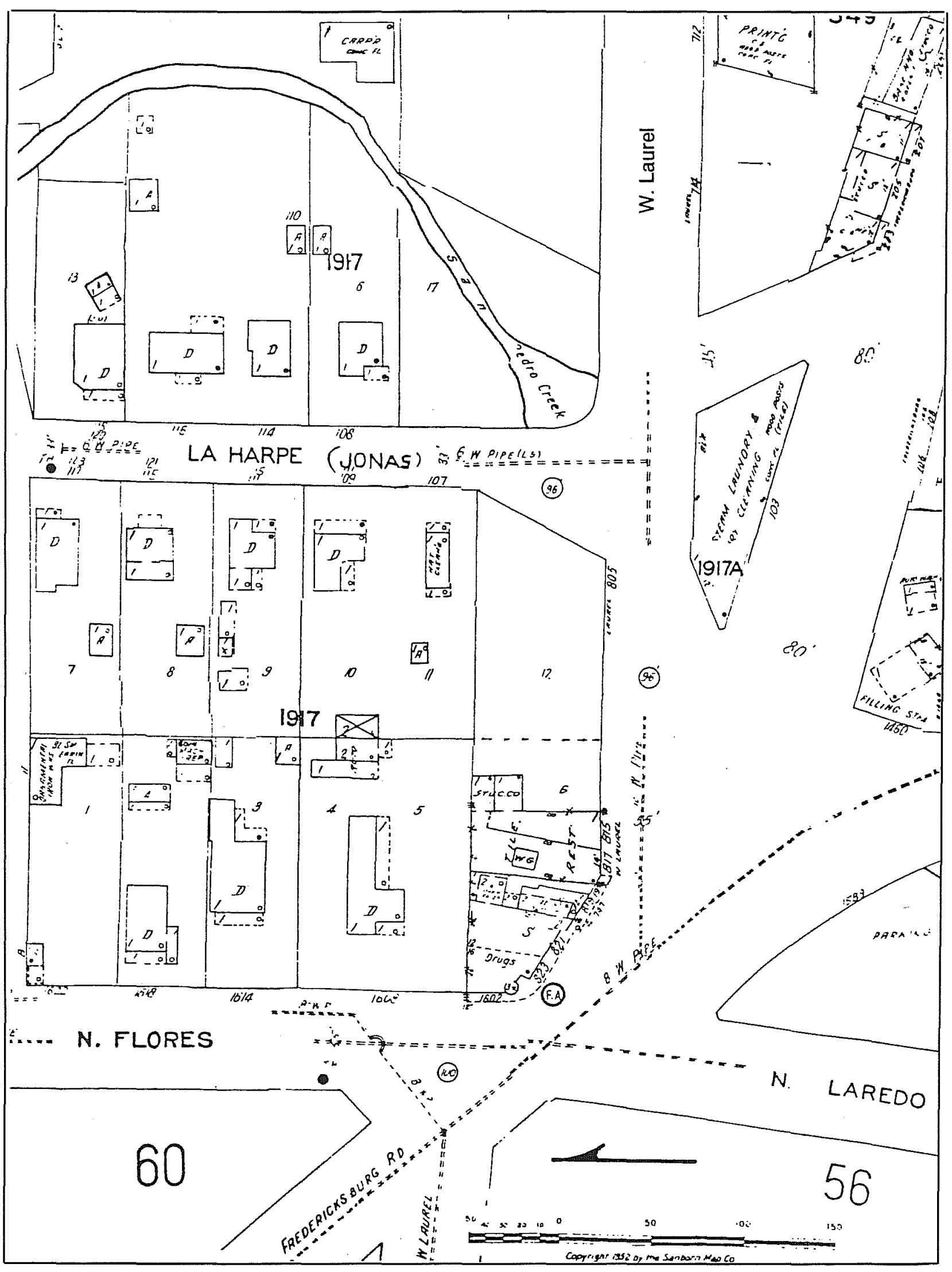

Figure 6. NCB 1917 in 1952. Sanborn Map and Publishing Company, Ltd. (1952). 


\section{REFERENCES CITED}

Appler, J. A.

1892 General Directory of the City of San Antonio, 1892-1893. San Antonio.

1895 General Directory of the City of San Antonio, 1895-1896. San Antonio.

1897 General Directory of the City of San Antonio, 1897-1898. San Antonio.

1899 General Directory of the City of San Antonio, 1899-1900. San Antonio.

1901 General Directory of the City of San Antonio, 1901-1902. San Antonio.

1903 General Directory of the City of San Antonio, 1903-1904. San Antonio.

1905 General Directory of the City of San Antonio, 1905-1906. San Antonio.

1907 General Directory of the City of San Antonio, 1907. San Antonio.

1908 General Directory of the City of San Antonio, 1908. San Antonio.

1909 General Directory of the City of San Antonio, 1909. San Antonio.

Austin, M. A.

1905 The Municipal Government of San Fernando de Bexar, 1730-1800. The Quarterly of the Texas State Historical Association VIII(4):277-354, April. Austin, Texas.

Bexar County, Texas

Deed Records (DR)

Originals and microfilm in the Bexar County Courthouse, San Antonio.

Land Grants and Sales (LGS)

County clerk's office, Bexar County Courthouse, San Antonio.

Wills and Probate Records

Originals in the Bexar County Courthouse, San Antonio.
Buck, S. M.

1980 Yanaguana's Successors, The Story of the Canary Islander's Immigration into Texas in the Eighteenth Century. Commemorative Edition. Robert M. Benavides, San Antonio. Originally published by Naylor Publishing Company, San Antonio, 1949.

Chabot, F. C

1937 With the Makers of San Antonio. Privately published, San Antonio.

City Survey Book

1850 City Engineer's Office, Main Plaza Building, San Antonio, Texas.

Crook, C. E.

1967 San Pedro Springs Park, Texas' Oldest Recreation Area. Privately published, San Antonio.

Moody and Morrison

1877 Directory of the City of San Antonio, 1877-1878. Galveston.

Morrison and Fourmy

1885 General Directory of the City of San Antonio, 1885-1886. Galveston.

1887 General Directory of the City of San Antonio, 1887-1888. Galveston.

1889 General Directory of the City of San Antonio, 1889-1890. Galveston.

Polk, R. L.

1958 Polk's San Antonio (Bexar County, Texas) City Directory. R. L. Polk and Company, Publishers, Dallas.

1970 Polk's San Antonio (Bexar County, Texas) City Directory. R. L. Polk and Company, Publishers, Dallas.

San Antonio Conservation Society

n.d. Five Points File. Repete-at-Pete's Building. San Antonio.

Sanborn Map and Publishing Company, Ltd. 1904 Map of San Antonio, Texas. New York. 1952 Map of San Antonio, Texas. New York. 
Texas Supreme Court Records

1883 Lewis et al. vs. City of San Antonio, Report of Cases Argued and Discussed of the State of Texas, Austin Term 1851, and a Part of Galveston Term 1852. Volume 7. E. F. Cushing, Houston.

Worley, J. F.

1926 San Antonio City Directory, 1926. San Antonio.

1927 San Antonio City Directory, 1927-1928. San Antonio.

1934- Worley's Miscellaneous City Directory, San

1935 Antonio, Texas. John F. Worley Directory Company, San Antonio and Dallas.

1938- Worley's Miscellaneous City Directory, San

1939 Antonio, Texas. John F. Worley Directory Company, San Antonio and Dallas.

1940- Worley's Miscellaneous City Directory, San 1941 Antonio, Texas. John F. Worley Directory Company, San Antonio and Dallas.

1942- Worley's Miscellaneous City Directory, San 1943 Antonio, Texas. John F. Worley Directory Company, San Antonio and Dallas.

1955- Worley's Miscellaneous City Directory, San 1956 Antonio, Texas. John F. Worley Directory Company, San Antonio and Dallas. 
